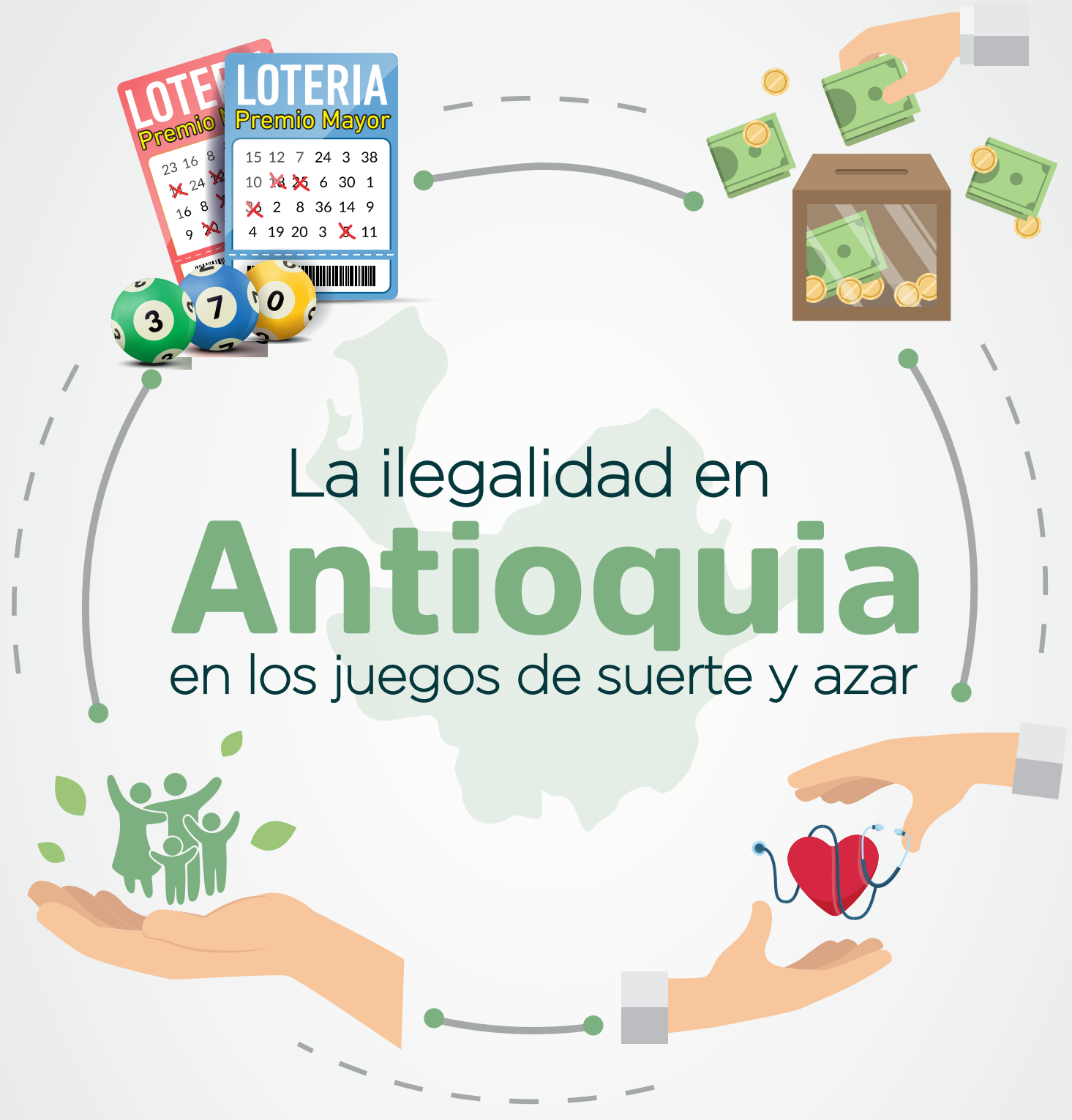




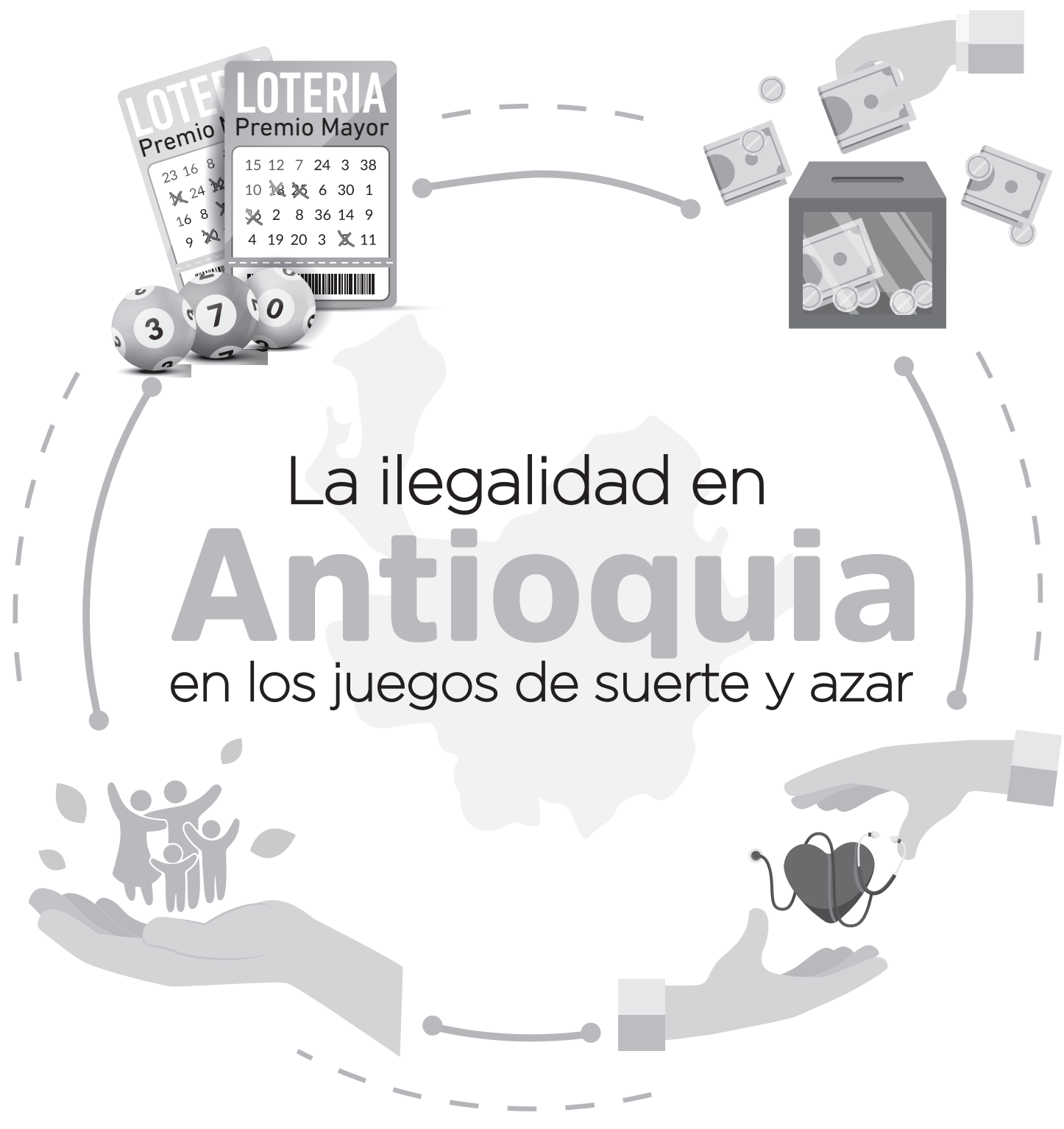
Gómez Zapata, Yuliana, Usma Zuleta, Leidy Jhojana, Zapata Álvarez, Luisa Fernanda, Echavarría Pérez, Ruth Julieth, Zapata Montoya, María Gardenia, Ceballos Urrego, Leonardo, investigadores. Ortiz Norela, Cristina, Vieira Colonia, Karen Sofía, auxiliares de investigación. Laínez, Gabriel Jaime, asesor externo.

La ilegalidad en Antioquia en los juegos de suerte y azar / Yuliana Gómez Zapata, Leidy Jhojana Usma Zuleta, Luisa Fernanda Zapata Álvarez, Ruth Julieth Echavarría Pérez, María Gardenia Zapata Montoya, Leonardo Ceballos Urrego, investigadores. Cristina Ortiz Norela, Karen Sofía Vieira Colonia, auxiliares de investigación. Gabriel Jaime Laínez, asesor externo.

Primera edición. Medellín: Sello Editorial Tecnológico de Antioquia Institución Universitaria, 2020

130 páginas

ISBN impreso: 978-958-53099-8-2

ISBN digital: 978-958-53099-7-5

Rentas públicas. Hacienda pública. Juegos de azar. Impuestos locales. Evasión de impuestos. Ilegalidad y crimen. Antioquia (Colombia: Departamento). Delitos económicos. Delincuentes. Administración pública. Salud - Aspectos sociales. Financiamiento de la salud. Salud pública. Salud - Aspectos económicos.

CDD: 336.986126

Catalogación en la publicación Biblioteca Humberto Saldarriaga Carmona - TdeA

ISBN impreso: 978-958-53099-8-2

ISBN digital: 978-958-53099-7-5

(c) Sello Editorial Tecnológico de Antioquia Institución Universitaria

Tecnológico de Antioquia

Calle 78 b \# 72 A - 220

(+57 4) 4443700

Medellín - Colombia

Corrección de estilo, diseño, diagramación e impresión

Divegráficas S.A.S.

Este libro incorpora contenidos derivados de procesos de investigación y estos no representan, necesariamente, los criterios institucionales del Tecnológico de Antioquia. Los contenidos son responsabilidad exclusiva de sus autores. Obra protegida por el derecho de autor. Queda estrictamente prohibida su reproducción, comunicación, divulgación, copia, distribución, comercialización, transformación, puesta a disposición o transferencia en cualquier forma y por cualquier medio, sin la autorización previa, expresa y por escrito de su titular. El incumplimiento de la mencionada restricción podrá dar lugar a las acciones civiles y penales correspondientes.

(c) 2020 Todos los derechos de autor reservados.

Hecho en Medellín, Colombia. 


\title{
La ilegalidad en \\ en los juegos de suerte y azar
}

\author{
Investigadores \\ Yuliana Gómez Zapata \\ Leidy Jhojana Usma Zuleta \\ Luisa Fernanda Zapata Álvarez \\ Ruth Julieth Echavarría Pérez \\ María Gardenia Zapata Montoya \\ Leonardo Ceballos Urrego \\ Auxiliares de investigación \\ Cristina Ortiz Norela \\ Karen Sofía Vieira Colonia
}

Asesor externo

Gabriel Jaime Laínez

Producto de investigación en el marco de la "Estrategia integral de control y fiscalización de los juegos de azar en el Área Metropolitana del Valle de Aburrá, para controlar la venta ilegal y la recuperación de recursos para Lotería de Medellín y el departamento de Antioquia"

Lotería de Medellín

Tecnológico de Antioquia - Institución Universitaria

Grupo de Investigación Observatorio Público

Medellín, Colombia

2020 


\section{Tecnológico} de Antioquia Institución Universitaria \} VIGILADA MINEDUCACIÓN
Leonardo García Botero

Rector

Andrea Aguilar Barreto

Vicerrectora Académica

Fabio Alberto Vargas Agudelo

Director de Investigación

José Albán Londoño Arias

Decano Facultad de Ciencias

Administrativas y Económicas

Yuliana Gómez Zapata

Directora del Grupo de Investigación

Observatorio Público

Aníbal Gaviria Correa

Gobernador de Antioquia

Luz Elena Gaviria López

Secretaria de Hacienda

Diana Patricia Salazar Franco

Subsecretaria de Hacienda

Ana Isabel Hernández Ríos

Directora de Rentas

Investigadores

Yuliana Gómez Zapata

Leidy Jhojana Usma Zuleta

Luisa Fernanda Zapata Álvarez

Ruth Julieth Echavarría Pérez

María Gardenia Zapata Montoya

Leonardo Ceballos Urrego 


\section{Autores}

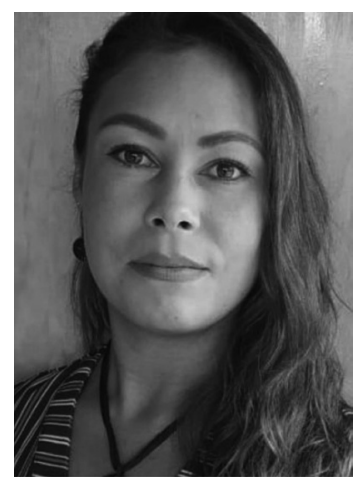

\section{Yuliana Gómez Zapata}

Contadora Pública y MSc. en Ciencias Contables de la Universidad de Antioquia - Colombia y candidata a doctora en Humanidades y Artes con mención en Ciencias de la Educación de la Universidad Nacional de Rosario - Argentina. Profesora asistente vinculada a la planta, directora del Grupo de Investigación Observatorio Público y directora editorial de la Revista En-Contexto de la Facultad de Ciencias Administrativas y Económicas del Tecnológico de Antioquia - Colombia.

ygomezza@tdea.edu.co

\section{Luisa Fernanda Zapata Álvarez}

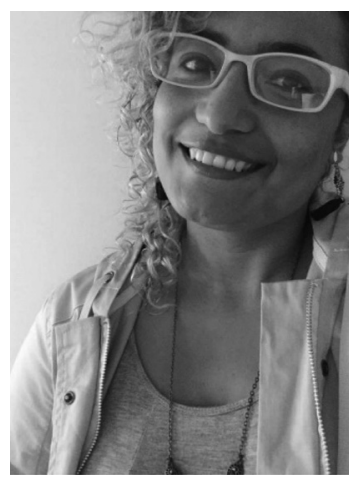

Psicóloga de la Universidad de Antioquia, especialista en Psicología Social Aplicada y MSc. en Psicología Social de la Universidad Pontificia Bolivariana Colombia. Estudiante de Doctorado en Ciencias Sociales de la Universidad Nacional de la Plata Argentina. Integrante de la Línea de Investigación en Contabilidad del Grupo de Investigación Observatorio Público de la Facultad de Ciencias Administrativas y Económicas del Tecnológico de Antioquia-Colombia, equipo de sistematización de la Estrategia Integral para el control de las rentas ilícitas del Tecnológico de Antioquia, Medellín - Colombia.

luisa.fza@gmail.com 

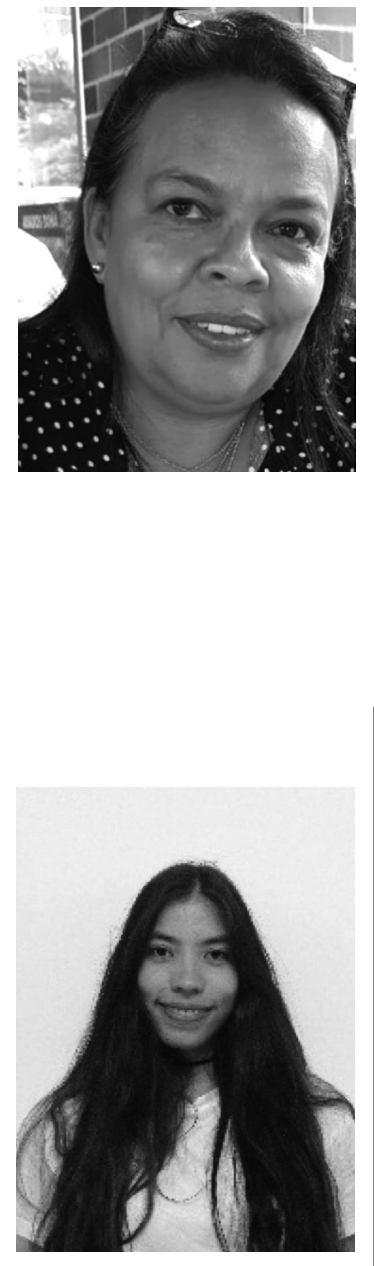

\section{María Gardenia Zapata Montoya}

Docente de la Facultad de Ciencias Sociales de la Institución Universitaria Colegio Mayor de Antioquia. Integrante dela Línea deInvestigaciónen Contabilidad del Grupo de Investigación Observatorio Público de la Facultad de Ciencias Administrativas y Económicas del Tecnológico de Antioquia - Colombia, equipo de sistematización de la Estrategia Integral para el control de las rentas ilícitas del Tecnológico de Antioquia, Medellín - Colombia.

gardeniazapata@hotmail.com

\section{Leidy Jhojana Usma Zuleta}

Contadora Pública del Politécnico Colombiano Jaime Isaza Cadavid. Integrante de la Línea de Investigación en Contabilidad del Grupo de Investigación Observatorio Público de la Facultad de Ciencias Administrativas y Económicas del Tecnológico de Antioquia - Colombia, equipo de sistematización de la Estrategia Integral para el control de las rentas ilícitas del Tecnológico de Antioquia, Medellín - Colombia.

jhojausma@gmail.com 


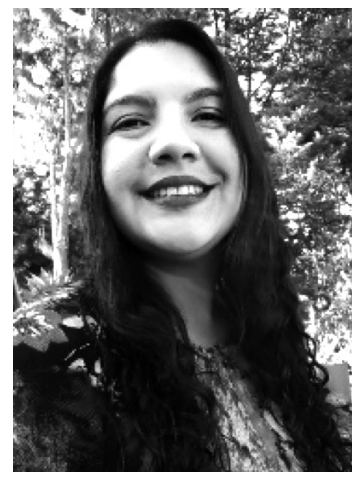

\section{Ruth Julieth Echavarría Pérez}

Contadora Pública y especialista en Gestión Tributaria de la Universidad de Antioquia. Asesora financiera y contractual en proyectos de extensión e investigación universitaria. Integrante de la Línea de Investigación en Contabilidad del Grupo de Investigación Observatorio Público de la Facultad de Ciencias Administrativas y Económicas del Tecnológico de Antioquia - Colombia, equipo de sistematización de la Estrategia Integral para el control de las rentas ilícitas del Tecnológico de Antioquia, Medellín - Colombia.

juliethe133@gmail.com

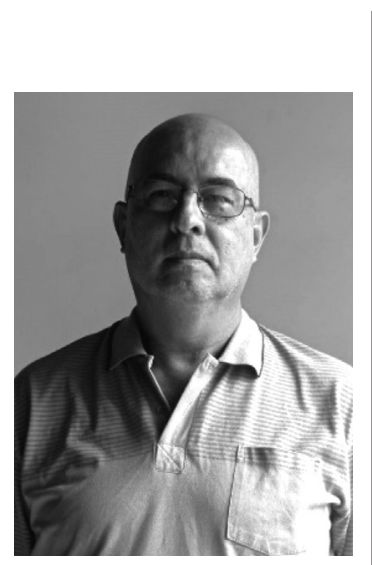

\section{Leonardo Ceballos Urrego}

Licenciado en Educación en el área de matemáticas de la Universidad de Medellín, especialista en Estadística de la Universidad Nacional y MSc. en Educación de la Universidad de Antioquia. Profesor vinculado a la planta de la Facultad de Ciencias Básicas del Tecnológico de Antioquia, Medellín -Colombia.

Iceu0457@gmail.com 



\section{Contenido}

Presentaciones institucionales ....................................... 9

Presentación Lotería de Medellín .................................... 9

Presentación Tecnológico de Antioquia ........................ 11

Sobre la Investigación.................................................... 13

Planteamiento del problema ........................................ 13

Objetivos de Investigación........................................... 16

Marco referencial ........................................................... 17

Marco contextual ......................................................... 17

Subregión Valle de Aburrá ............................................... 17

Subregión Oriente Antioqueño ....................................... 18

Subregión del Bajo Cauca .............................................. 19

Subregión Magdalena Medio ........................................ 20

Subregión Nordeste ........................................................ 21

Subregión Occidente antioqueño ..................................... 21

Subregión Norte de Antioquia ......................................... 23

Subregión Urabá antioqueño ........................................... 23

Subregión Suroeste antioqueño ..................................... 24

Antecedentes de investigación ....................................... 25

Sociedad, cultura y juegos de suerte y azar ................... 25

Juegos de suerte y azar: impuestos y legalidad .............. 27

Proyecto de investigación .............................................. 31

Marco Conceptual ....................................................... 34

Juegos de suerte y azar ................................................ 34

Ilegalidad ................................................................... 37

Defraudación .................................................................. 39

Marco metodológico .................................................. 41

Técnicas de recolección de información ......................... 43

Análisis de datos estadísticos ........................................ 44

Resultados ................................................................... 46

Rastreo de archivo de noticias ...................................... 46 
Chance y apuestas ilegales

Bandas en el negocio de las apuestas ilegales ................. 48

Análisis por categorías .................................................... $\quad 50$

La Función del estado: instituciones de Antioquia ............. 51

Sobre el pago de impuestos en los juegos de suerte y azar 59

Prácticas de llegalidad en los juegos de suerte y azar ....... 62

Posturas comunitarias y su relación con la salud .............. 74

Resultados de la medición de la defraudación .................. 80

Discusión, conclusiones y recomendaciones .................. 86

Sobre las prácticas de ilegalidad ..................................... 87

¿Cuál es la relación con el sector salud? ......................... 92

Conclusiones ................................................................ 99

Recomendaciones ............................................................ 101

Importancia de la medición de impacto ............................. 101

Aspectos sociales y comunitarios ...................................... 102

Aspectos institucionales .................................................. 103

Aspectos económicos ........................................................ 104

Aspectos de control y sanción ............................................ 105

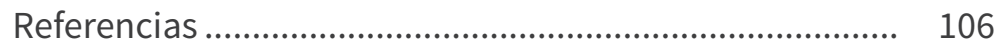

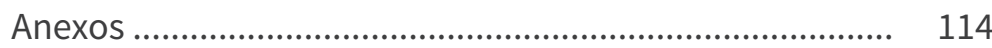




\section{Presentaciones institucionales}

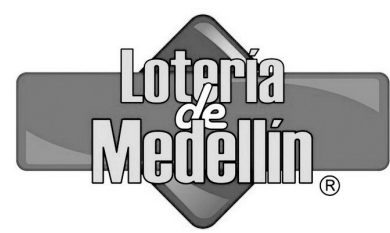

\section{Presentación Lotería de Medellín}

La Lotería de Medellín, como empresa encargada de recaudar recursos que se invierten en proyectos y programas para la salud de la población antioqueña, se obliga a enfrentar las prácticas ilegales que los desvían, implementando acciones orientadas a fortalecer, dentro de la población, hábitos enmarcados en una cultura de legalidad.

Esta empresa hace parte de la cartera de la Gobernación de Antioquia y se ha propuesto llevar a cabo acciones que mejoren el flujo de las rentas departamentales; procesos que impulsan dichos hábitos culturales y que enfrentan todo ejercicio que atente contra los recursos departamentales destinados a la atención de la población antioqueña.

En aras de cumplir con su objetivo -el control de losjuegos de suerte y azar en Antioquia-, la Lotería de Medellín también busca estrategias que le permitan asegurar el efectivo recaudo de aquellos dineros que garantizan el desarrollo de los programas de atención en salud, fundamentalmente. Es por ello que se inscribe en las dinámicas de la estrategia 
integral al control de las rentas ilícitas con acciones que buscan combatir los fraudes y minimizar los riesgos que afectan dichos ingresos.

Esta estrategia se traduce en una serie de acciones encaminadas a contrarrestar las diferentes formas de evadir los controles establecidos a los recursos que deben ingresar al departamento y sus dependencias. Dentro de las que se llevan a cabo, con el objetivo de vigilar y garantizar un efectivo recaudo, la Lotería Medellín se propone crear grupos operativos que obtengan la información pertinente para propiciar actividades enfocadas a la creación de una cultura de la legalidad.

Es así como el camino hacia una cultura de la legalidad incluye procesos de sensibilización, capacitación, comunicación y participación ciudadana que se concretan con el conocimiento teórico y práctico adquirido a través de instituciones de carácter educativo vinculadas al programa - como el Tecnológico de Antioquia-Institución Universitaria-.

Así pues, la Lotería de Medellín espera que con la implementación de este proyecto se generen procesos de visibilidad, reconocimiento y sistematización de buenas prácticas de la cultura de la legalidad, teniendo como base los aportes del Tecnológico de Antioquia, aliado que aporta al propósito con su experiencia en investigación y proyección a la comunidad.

David Mora Gómez

Gerente Lotería de Medellín 


\section{Tecnológico}

de Antioquia

Institución Universitaria \}

VIGILADA MINEDUCACIÓN

\section{Presentación Tecnológico de Antioquia}

El Tecnológico de Antioquia, Institución Universitaria del departamento, desde los procesos de extensión e investigación - principios misionales de la institución-, consolida convenios con diferentes sectores de la sociedad, orientados a la formación continua y a la transformación de prácticas socioculturales que contribuyen a mejorar los factores económicos, culturales y sociales que afectan a la población antioqueña.

A partir de convenios realizados con entidades públicas, como la Lotería de Medellín, el Tecnológico de Antioquia propone estrategias orientadas a impactar a las comunidades. Estas pueden constituir proyectos de investigación liderados por grupos de las diferentes facultades de la institución que, a su vez, se consolidan en el marco de la interacción con el sector educativo, productivo y de servicios.

En este sentido, el Tecnológico de Antioquia y la Lotería de Medellín vienen trabajando en el reconocimiento de prácticas ilegales en torno a los juegos de suerte y azar. Para el caso, el grupo de investigación Observatorio Público, adscrito a la Facultad de Ciencias Administrativas y Económicas, desarrolla este componente con el objetivo de contribuir a la generación de buenas prácticas en lo que se refiere al recaudo de los impuestos que generan los juegos de suerte y azar, como fuente para la inversión social en la salud de la población. 
Desde la experiencia interinstitucional, la Facultad propone estrategias efectivas para socializar y sensibilizar a la comunidad antioqueña y, desde ahí, generar acciones que contribuyan a mejorar los factores económicos, culturales y sociales.

El Tecnológico de Antioquia, desde la perspectiva de la investigación, se acerca al análisis de los comportamientos sociales en lo que tiene quever con las prácticasilegales en torno a los juegos de suerte y azar para presentar, finalmente, como resultado del ejercicio académico, el presente producto,que permite acercarse al fenómeno de la ilegalidad en los juegos de suerte y azar en Antioquia.

Yuliana Gómez Zapata

Directora Grupo de Investigación Observatorio Público Tecnológico de Antioquia - I.U. 


\section{Sobre la}

\section{investigación}

\section{Planteamiento del problema}

La Lotería de Medellín, como entidad descentralizada del departamento de Antioquia, ha venido haciendo esfuerzos para robustecer el recurso público que se invierte en la salud de los antioqueños (Asamblea Departamental de Antioquia, 2017, art. 17). Esta entidad, de acuerdo con el Estatuto de Rentas y a la Ley 643 del 2001, es responsable de la concesión de las rentas de los juegos de suerte y azar, la cual hace referencia a "la explotación del monopolio como árbitro rentístico de las loterías tradicionales, del juego de las apuestas permanentes o chance, rifas, sorteos promocionales y eventos hípicos" (Asamblea Departamental de Antioquia, 2017, art. 20).

En este marco, desde el 2016, en cabeza de la Gobernación de Antioquia, se vienen implementando estrategias para consolidar acciones y prácticas ciudadanas e institucionales que permitan dar cuenta de una cultura de la legalidad. En este sentido, cabe anotar que por juegos de suerte y azar se entiende:

... aquellos en los cuales, según reglas predeterminadas por la ley y el reglamento una persona que actúa en calidad de jugador, efectúa una apuesta o paga por el derecho a participar, a otra persona que actúa en calidad de operador, quien le ofrece a cambio un premio, en dinero o en especie, el cual ganará si acierta, dados los resultados del juego, no siendo este previsible con certeza, por estar determinado por la suerte, por el azar o por la casualidad (Asamblea Departamental de Antioquia, 2017, art. 22). 
De manera que, a la Lotería de Medellín ingresan recursos por distintos tipos de juegos de suerte y azar; sin embargo, a través de la experiencia y experticia de la entidad, se han identificado cuatro juegos en los que específicamente se ha centrado la estrategia integral al control de este monopolio rentístico $y$, en los que se enmarca la presente investigación. De esta forma el chance, rifas, sorteos promocionales y la Lotería de Medellín son los focos de atención para intervención e investigación, considerando que en estos cuatro tipos de juegos es donde se cometen fraudes o ilícitos de manera más recurrente en los distintos lugares del territorio antioqueño.

El chance, o juego de apuestas permanentes, se refiere a la elección, por parte de un jugador,

... de un número de máximo cuatro (4) cifras; [sta] se realiza a través de un formulario oficial y se efectúa de manera sistematizada. De acuerdo a las reglas del juego se determina si el número concuerda con el resultado del premio mayor del juego autorizado y por esto recibe un premio en dinero, de acuerdo con un plan de premios predefinido y autorizado por el Gobierno Nacional mediante decreto reglamentario. La explotación de las apuestas permanentes o chance se realiza a través de formularios diligenciados en forma sistematizada e impresos en papel de seguridad, agrupados en rollos u hojas continuas y sus dimensiones determinadas por la entidad concedente. (Gómez et al., 2017, pp. 61-62)

En el caso de las rifas, se sortean premios entre las personas que compraron una o más boletas; estas tienen un número en serie y un precio fijo, y el sorteo se lleva a cabo en una fecha específica. El distribuidor de las rifas en Antioquia debe estar autorizado por la Lotería de Medellín y realizar el pago de impuestos (Gómez et al., 2017). Por su parte, los sorteos promocionales se realizan con el fin de hacer publicidad a un establecimiento, empresa u entidad, ofreciendo un premio al público; las modalidades de participación varían de acuerdo a la entidad (Gómez et al., 2017). Y sobre las loterías tradicionales, estas funcionan:

... poniendo a circular billetes que se fraccionan o no y que tienen un precio fijo, estos billetes tienen una combinación de números o caracteres visibles que permiten diferenciarlos de otros. Luego de 
sortear la combinación que tenga algún billete, es necesario otorgar un premio en dinero. (Gómez et al., 2017, p. 61)

Teniendo en cuenta los juegos de suerte y azar anteriormente mencionados, de acuerdo con las disposiciones normativas de la Ordenanza 029 (Asamblea Departamental de Antioquia, 2017), existen los juegos prohibidos y prácticas no autorizadas que tienen que ver con:

a. La circulación o venta de juegos de suerte y azar cuya oferta disimule el carácter aleatorio del juego o sus riesgos;

b. El ofrecimiento o venta de juegos de suerte y azar a menores de edad y a personas que padezcan enfermedades mentales, que hayan sido declaradas interdictas judicialmente;

c. La circulación o venta de juegos de suerte y azar, cuyos premios consistan o involucren directa o indirectamente bienes a servicios que violen los derechos fundamentales de las personas o atenten contra las buenas costumbres;

d. La circulación o venta de juegos de suerte y azar que afecten la salud de los jugadores; la circulación o venta de juegos de suerte y azar cuyo premio consista o involucre bienes o servicios que las autoridades deban proveer en desarrollo de sus funciones legales;

e. La circulación, venta u operación de juegos de suerte y azar cuando se relacionen o involucren actividades, bienes a servicios ilícitos a prohibidos, y

f. La circulación, venta u operación de juegos de suerte y azar que no cuenten con la autorización de la entidad a autoridad competente, desconozcan las reglas del respectivo juego o los límites autorizados. (Art. 21)

En esta vía de prácticas no autorizadas y prohibiciones se han identificado cuatro ilícitos o fraudes a partir de los cuales se busca centrar la presente investigación, no solo sobre su configuración como ilícito, sino también sobre sus efectos e impactos en el territorio antioqueño. Estos son: el chance manual, las rifas y los sorteos promocionales no autorizados; la falsificación y adulteración de billetes de lotería, que son las prácticas más frecuentes que se desarrollan al margen de la ley, y que configura acciones de mayor 
complejidad a nivel de fortalecimiento del recurso público. Es así como desde esta investigación se busca responder el siguiente interrogante icómo fortalecer la estrategia al control integral al monopolio rentístico de juegos de suerte y azar en el departamento de Antioquia?

\section{Objetivos de Investigación}

\section{Objetivo General}

Fortalecer la estrategia de control integral al monopolio rentístico de juegos de suerte y azar en el departamento de Antioquia.

\section{Objetivos Específicos}

- Conocer las prácticas de ilegalidad relacionadas con el monopolio de juegos de suerte y azar en el departamento de Antioquia.

- Identificar la defraudación económica en el monopolio de juegos de suerte y azar a partir de las aprehensiones desarrolladas en el marco de los operativos realizados en el departamento de Antioquia.

- Describirla relación entre las consecuencias de la ilegalidad en el monopolio de juegos de suerte y azar con la destinación del impuesto al sector salud. 


\section{Marco} referencial

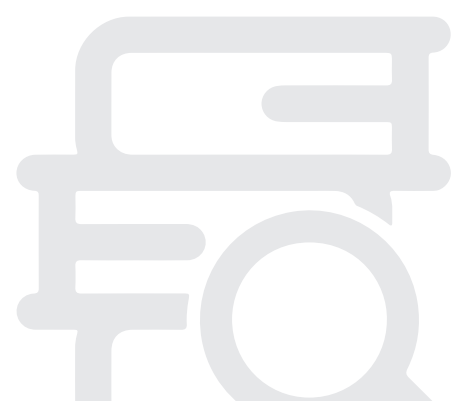

A continuación, se presenta el marco contextual donde se describen las distintas subregiones del departamento de Antioquia y algunos aspectos en relación a los juegos de suerte y azar que se presentan en cada una de ellas. A su vez, se describen los antecedentes de investigación encontrados y que establecieron el marco académico en el que se desarrolló la pregunta de investigación y, por último, el marco conceptual que permitió dar cuenta de los fundamentos teórico-conceptuales de la investigación.

\section{Marco contextual}

El departamento de Antioquia se subdivide en nueve subregiones, las cuales tienen unas características geográficas, políticas, culturales, económicas y sociales con sus particularidades frente a los juegos de suerte y azar; es por esto que se considera importante presentar algunos elementos del contexto de cada subregión y la descripción que realizaron algunos funcionarios de los municipios que las conforman, con respecto a la problemática de este trabajo.

\section{Subregión Valle de Aburrá}

Una de las subregiones que componen el departamento de Antioquia es el Valle de Aburrá, ubicado en el centro-sur del departamento, del cual hacen parte los municipios de Barbosa, Girardota, Copacabana, Bello, Medellín, Envigado, Itagüí, Sabaneta, La Estrella y Caldas. Esta subregión ha tenido un rápido crecimiento poblacional y urbanístico, fundamentado en la llegada de población desplazada por el conflicto armado; el proceso de industrialización 
y su generación de empleo, y el negocio del narcotráfico, entre otros. De acuerdo con la información de los censos del DANE, en esta subregión la población se concentra en el área urbana, siendo más representativa la población femenina, con predominancia del grupo de jóvenes y adultos; concentración que dio paso al desarrollo de la infraestructura urbana.

La población de esta subregión cuenta con una alta cobertura educativa, principalmente en el nivel de básica primaria; en cuanto a la salud, tiene el mayor número de afiliados al régimen contributivo (Corantioquia, 2015, p. 1503) y la vivienda es una situación que genera mayor problema por su calidad que por la cantidad (Corantioquia, 2015, p. 1552).

\section{Sobre los juegos de suerte y azar}

Con relación a los juegos de azar, los resultados de las encuestas realizadas en los municipios evidencian que Medellín, Caldas, Envigado y La Estrella es donde más se expresan las prácticas de ilegalidad, siendo las más frecuentes la evasión de impuestos del chance ilegal, la adulteración o falsificación de los billetes de lotería y sorteos promocionales, y las rifas sin la debida autorización; dichas encuestas hablan de que las prácticas de ilegalidad tienen efectos e impactos negativos en distintas dimensiones:

... se afecta principalmente la ley, y con ello la dinámica social de los territorios; se ven afectadas las condiciones sociales, económicas de los comerciantes, e indudablemente el ámbito legal. [Hay afectación] social por la confianza que se pierde, económica, y por las afectaciones que puede traer en la salud, al igual que lo legal, por el incumplimiento a la normativa grave para el desarrollo económico e inversión en lo social. (Persona encuestada)

\section{Subregión Oriente antioqueño}

Esta subregión está localizada en el suroriente del departamento de Antioquia y centro de la geografía colombiana, entre el cañón del Cauca, los corredores de los ríos Magdalena, Medellín-Porce y el Nus. A esta subregión la integran los municipios de Abejorral, Alejandría, Argelia, Cocorná, Concepción, El Carmen de Viboral, El Peñol, El Retiro, El Santuario, Granada, Guarne, Guatapé, La Ceja, 
La Unión, Marinilla, Nariño, Rionegro, San Carlos, San Francisco, San Luis, San Rafael, San Vicente y Sonsón. Es una subregión con una población aproximada de 595.030 habitantes, según proyecciones del DANE para 2018 (Cámara de Comercio, Oriente Antioqueño, 2018, p. 7). El municipio de Rionegro presenta la mayor densidad poblacional. El desarrollo empresarial para el oriente antiqueño presenta un comportamiento creciente en el tiempo, dinamizando aspectos económicos con condiciones favorables para expansión (Cámara de Comercio, Oriente Antioqueño, 2018, p. 98).

El oriente antioqueño tiene algunas ventajas, dadas por la geografía: las fuentes hídricas, los paisajes y la fertilidad en los suelos, así como también la cobertura de todos los niveles de educación que han aportado a la industrialización; pero las zonas más alejadas de la capital del departamento presentan una población rural con brechas en términos de pobreza y déficit en la garantía de los derechos sociales.

\section{Sobre juegos de suerte y azar}

De acuerdo con las encuestas, las acciones que reconocen los funcionarios a partir de la ilegalidad en los juegos de suerte y azar tienen que ver con la afectación a las dinámicas sociales a la economía municipal y, por tanto, a la inversión social, siendo El Carmen de Viboral, El Retiro, San Rafael, El Santuario, Sonsón, Abejorral, Rionegro y La Unión los municipios que reportan prácticas de ilegalidad recurrentes en juegos de suerte y azar. La práctica más frecuente es la evasión de impuestos por rifas y sorteos promocionales no autorizados. Al respecto, algunos participantes dicen, particularmente sobre las rifas ilegales, que las personas que se dedican a esa práctica saben que las rifas deben pagar impuestos y, aun así, cometen la ilegalidad.

\section{Subregión del Bajo Cauca}

Se encuentra ubicada dentro del territorio antioqueño, en la cordillera Central, entre los ríos Cauca y Nechí. Se caracteriza por la explotación del oro; pero, para las últimas décadas del siglo XX, se intensificaron los cultivos de coca como fuente de ingresos para la población asentada en la zona (Reyes, Amaya y Pedraza, 2011, p. 22). La integran los municipios de Zaragoza, El Bagre, Nechí, Tarazá, Caucasia y Cáceres. Con un total de 320.000 habitantes, 
aproximadamente. Según las proyecciones poblacionales del DANE (2018), la población que habita la subregión es una población relativamente joven, pues esta, en conjunto, representa el $61,7 \%$ de sus habitantes (Comfenalco Antioquia, 2018, p. 4).

Las condiciones económicas que caracterizan la población asentada en la subregión del Bajo Cauca Antioqueño dan paso a la expansión de la pobreza, la falta de oportunidades y el incremento de necesidades no satisfechas; situaciones que redundan en dificultades para el desarrollo y que no contribuyen a incrementar la calidad de vida de sus pobladores, quienes sin tierra y sin recursos optan por vincularse a las únicas oportunidades que solo brindan las actividades ilegales (PNUD, 2011, p. 22).

\section{Sobre juegos de suerte y azar}

En las encuestas realizadas no se presentaron datos relevantes sobre juegos de suerte y azar, debido a que hubo dificultades para recoger información en ese territorio. Sin embargo, de acuerdo a la información recogida por otras fuentes, la evasión de impuestos en materia de juegos de suerte y azar se ejecuta en todo del departamento, aunque se concentra en unas zonas específicas, como se podrá reconocer a lo largo del este texto.

\section{Subregión Magdalena Medio}

Situada al oriente de Antioquia, en la franja que limita con el río Magdalena; está conformada por los municipios de Caracolí, Maceo, Puerto Berrío, Puerto Nare, Puerto Triunfo y Yondó. Su ubicación es estratégica para la comunicación interdepartamental y el desarrollo regional. En ese sentido, Yondó y Puerto Berrío tienen la mayor parte de la población de la subregión, la cual está en condiciones de pobreza o miseria (Corantioquia, 2018), a pesar de ser una región rica en recursos naturales, destacada por la ganadería y, especialmente, Yondó, por la refinación de petróleo (Finkeros, 2013). Esta subregión tiene un gran déficit en el acceso a la educación formal y en la calidad y cantidad de viviendas - especialmente ubicadas en la zona urbana-, por lo que se demandan procesos de mejoramiento. 


\section{Sobre juegos de suerte y azar}

En la subregión del Magdalena Medio se enfatiza en la evasión de impuestos como práctica de ilegalidad asociada a los juegos de suerte y azar, fundamentalmente en lo que tiene que ver con los sorteos promocionales y las rifas no autorizadas que, como se ha dicho antes, son conductas presentes en todo el departamento. En las entrevistas se manifiesta que en la región se suelen hacer rifas que no cuentan con la debida autorización y, por tanto, no realizan el pago del impuesto.

\section{Subregión Nordeste}

Está ubicada sobre la margen oriental de la cordillera Central, al suroeste de la serranía de San Lucas y entre los ríos Porce, Nechí, Nus y Alicante, y de ella hacen parte los municipios de Yalí, Amalfi, Anorí, Cisneros, Segovia, Remedios, Yolombó, Vegachí, San Roque y Santo Domingo. Con aproximadamente 189.781 habitantes, es una zona rica en producción maderera y minera, fundamentalmente el oro (producen el $74 \%$ del oro del país), que despierta el interés de agentes externos a los pobladores de la región y desata conflictos por el dominio de su explotación entre las grandes trasnacionales del oro y los grupos armados paramilitares y guerrilleros (Bernal, 2018, p. 67). La población que habita la subregión es relativamente joven dado que, en conjunto, representa el 57,4\% de sus habitantes (Comfenalco, Antioquia, 2018).

En el nordeste hay presencia de actores armados ilegales; recursos escasos en materia fiscal para actuar como Estado en lo municipal; bajos niveles de formación ciudadana para la interacción con los gobiernos y la gestión pública; precaria o nula información sobre el desempeño de la gestión pública, unido a la poca confianza de sus habitantes frente a lo que hacen los gobiernos y partidos; debilidad de espacios ciudadanos apropiados para hacer seguimiento y control y generen propuestas de mejoramiento de las acciones públicas en bien de la población y de buenos gobiernos (IPC, 2017a).

\section{Sobre juegos de suerte y azar}

Los funcionarios y contratistas encuestadores tampoco reportaron información del nordeste antioqueño que evidencien las prácticas masivas de ilegalidad; sin embargo, como en otras subregiones, las rifas ocasionales 
y no autorizadas son prácticas frecuentes. La dificultad que expusieron, es que este tipo de actividades son difíciles de controlar, si se considera que, en muchos casos, son prácticas que se llevan a cabo cotidianamente y en el marco de contextos familiares, escolares y comunitarios, entre otros.

\section{Subregión Occidente antioqueño}

La subregión del Occidente de Antioquia está ubicada entre las cordilleras Central y Occidental de Colombia, entre el Valle de Aburrá, al sur, y el Nudo de Paramillo y Urabá, al norte. Se constituye en la principal ruta de conexión del Área Metropolitana del Valle de Aburrá (AMVA) con el Urabá y con el mar Caribe. La subregión está integrada por los municipios de Abriaquí, Cañasgordas, Dabeiba, Frontino, Peque y Uramita; Anzá, Armenia, Buriticá, Caicedo, Ebéjico, Giraldo, Heliconia, Liborina, Olaya, Sabanalarga, San Jerónimo, Santa Fe de Antioquia y Sopetrán. Son territorios que, por sus características de biodiversidad, poblacionales, geográficamente estratégicas e históricas, poseen enormes potencialidades para el desarrollo agrícola y turístico (Velásquez, 2016). La población que habita la subregión es relativamente joven, menor de 30 años. Según el Dane, la mayor parte de la población vive en la ruralidad, que asciende al 85 \%; sin embargo, esto no implica una marcada vocación campesina, con su respectivo uso del suelo, ya que fenómenos en reciente auge como el turismo han modificado las dinámicas sociales de algunos municipios (Corantioquia, 2017, p. 1056), situación que da origen al cambio de vocación de uso del suelo, que dejó de ser agrícola para perfilarse como turístico.

En el aspecto económico, las actividades comerciales son las que ocupan el primer lugar, seguidas de alojamiento y servicio de comidas, que hacen parte de la vocación productiva de la subregión. En menor medida se encuentran la industria manufacturera, otras actividades de servicio, explotación de minas y canteras, construcción y agricultura, ganadería, caza, silvicultura y pesca (Comfenalco, Antioquia, 2018, p. 6).

\section{Sobre juegos de suerte y azar}

Con relación a las prácticas de juegos de suerte y azar, la población encuestada en los municipios informa que la práctica más frecuente tiene 
que ver con la evasión de impuestos de las rifas y sorteos promocionales no autorizados. En estos municipios se presentan unas reflexiones interesantes, en la medida en la que se proponen algunos asuntos para tener en cuenta en su intervención, como se advierte a continuación:

Si bien es cierto que al municipio llegan las rifas sin autorización, también es cierto que alrededor de 100 familias consiguen sus ingresos a través de esta actividad de venta de boletas, lo que afecta el ingreso de recursos para la salud. (Persona encuestada)

Este planteamiento es importante tenerlo en cuenta, no solamente en esta subregión, sino como una práctica que acontece en todo el departamento y que en muchos casos no está necesariamente conectada con actores armados, quienes también incurren en estas prácticas.

\section{Subregión Norte de Antioquia}

El Norte de Antioquia está ubicado en una de las ramificaciones de la cordillera Central, entre el Área Metropolitana del Valle de Aburrá, al sur, y el Nudo de El Paramillo. Su riqueza hídrica viene siendo explotada para la generación de energía en cuatro embalses y un megaproyecto (IPC, 2017b). Los municipios que lo integran son: Belmira, Don Matías, Entrerríos, San Pedro de los Milagros, Santa Rosa de Osos, Angostura, Briceño, Campamento, Valdivia, Yarumal, Ituango, San Andrés de Cuerquia, San José de la Montaña, Toledo, Carolina del Príncipe, Gómez Plata y Guadalupe. Es la cuarta subregión con mayor desarrollo en el departamento de Antioquia; la presencia de actores armados ilegales y débil presencia del Estado son una constante; los recursos en materia fiscal para actuar como Estado en lo municipal son escasos; tiene bajos niveles de formación ciudadana para la interacción con los gobiernos y la gestión pública; la información sobre el desempeño de la gestión pública es precaria o nula, a lo que se suma la poca confianza de sus habitantes frente a lo que hacen los gobiernos y partidos (IPC, 2017b). Según el Dane, para el año 2016, la subregión tenía 261.411 habitantes.

La economía del Norte de Antioquia depende básicamente del sector pecuario de ganadería lechera. La transformación de la leche y la producción de 
energía han generado actividades de abastecimiento de servicios sociales, comerciales, de transporte, almacenamiento y comunicaciones para la subregión (Aramburo et al., 2007, p. 73).

\section{Sobre juegos de suerte y azar}

En esta región hay una amplia tradición en las prácticas de ilegalidad en los juegos de suerte y azar, particularmente en la circulación y venta de rifas no autorizadas, que revierte en evasión de impuestos y, con ello, se afectan los dineros para la salud. En el presente año, en los municipios de Santa Rosa y Entrerríos, al igual que en municipios del oriente antioqueño, en los operativos realizados se logró desestructurar la banda Los Yanes, reconocidos como organización dedicada a la venta de rifas ilegales.

\section{Subregión Urabá antioqueño}

Como región costera es una de las más extensas del departamento; se destaca por su biodiversidad natural y pluriculturalidad; se le reconoce como una fuente de gran potencial hídrico, forestal y de expansión de mercados, debido a las grandes posibilidades para la interconexión e integración económica. Contempla parte de los departamentos de Chocó, Antioquia y Córdoba, se extiende desde el valle del Sinú hasta la cuenca del Atrato y abarca la cuenca del golfo de Urabá y parte del Nudo de Paramillo (Comfenalco Antioquia, 2018, p. 3). Está integrada por los municipios de Arboletes, Apartadó, Carepa, Chigorodó, Mutatá, Murindó, Necoclí, San Juan de Urabá, San Pedro de Urabá, Turbo y Vigía del Fuerte. Es la región bananera y platanera más importante del país; aun así, la población de Urabá es una de las que tiene menor calidad de vida y se enfrenta constantemente a problemas de violencia y desplazamiento - factores negativos que dificultan su desarrollo-. Ha sido una región que ha vivido la confrontación armada de manera dramática (IPC, 2017c).

\section{Sobre juegos de suerte y azar}

Los funcionarios y contratistas encuestadores no dieron reportes sobre prácticas de ilegalidad en el marco de los juegos de suerte y azar en el Urabá antioqueño; no obstante, como en otras subregiones, en esta región existen prácticas frecuentes como las rifas ocasionales no autorizadas. 


\section{Subregión Suroeste antioqueño}

El suroeste antioqueño se encuentra localizado entre las cordilleras Occidental y Central, que conforman el cañón del río Cauca y la cuenca del río San Juan (Universidad de Antioquia, 2012, p. 302), del que hacen parte los municipios de Caramanta, Jericó, La Pintada, Montebello, Pueblorrico, Santa Bárbara, Támesis, Tarso y Valparaíso; Penderisco, Betulia, Concordia, Salgar y Urrao; San Juan de Andes, Betania, Ciudad Bolívar, Hispania y Jardín, y Sinifaná, Amagá, Angelópolis, Fredonia, Titiribí y Venecia. La subregión está habitada por una población relativamente joven, concentrada en la zona rural, más que en la urbana (Comfenalco, Antioquia, 2018, p. 3). Su economía se fundamenta en la caficultura, la minería de carbón, el turismo, y la producción de plátano, caña panelera, frutales, fríjol, hortalizas, yuca, papa y maíz.

La actividad turística se ha fomentado en los últimos años, en la que se destaca el municipio de Jardín, ya que es pionero en el desarrollo de atractivos turísticos novedosos, como las trucheras. Por su parte, el municipio de Andes es considerado un centro de escala, por ser la conexión con Jardín, además, cuenta con finca-hoteles en las que el turista puede conocer a fondo el proceso de elaboración del café (Cámara de Comercio, 2019, p. 33).

\section{Sobre juegos de suerte y azar}

En esta subregión también se evidencian asuntos de orden reiterativo alrededor de las rifas y sorteos promocionales no autorizados, y se presenta la particularidad mencionado en otras subregiones, y es la realización de las rifas no autorizadas, lo que puede tener tres causas: 1) Se presentan como un sustento cotidiano para las familias; 2) las realizan otros grupos sociales o comunitarios para la obtención de recursos, y 3 ) hay grupos ilegales que propenden por su uso. Con respecto a este escenario, una persona encuestada nos advierte que estas situaciones tienen unas causas de orden "social y económico, porque es una renta de supervivencia para varias familias, y legal, porque ayuda a los dueños de las rifas a desarrollar actividades de lavado de activos" (persona encuestada). 


\section{Antecedentes de investigación}

La revisión de los antecedentes de investigación en relación con el monopolio de juegos de suerte y azar tuvo lugar usando las siguientes fórmulas de búsqueda: Juegos de suerte y azar + impuestos, juegos de suerte y azar + Antioquia, juegos de suerte y azar + ilegalidad, juegos de suerte y azar + impacto; estas búsquedas se realizaron inicialmente entre 2016 y 2019, pero, debido a la poca información encontrada, se amplió la búsqueda a documentos que datan desde el 2001, teniendo en consideración que estos también nutrirían estos antecedentes; es decir, de manera general, después de esa fecha se encontraron artículos de investigación, tesis de pregrado y posgrado e informes de instituciones que abordan el tema de juegos de suerte y azar desde distintas dimensiones. Como resultado de dicha búsqueda se construyeron dos grandes categorías: Juegos de suerte y azar: impuestos y legalidad; y Sociedad, cultura y juegos de suerte y azar. Asimismo, en este apartado se relacionan los textos que anteceden la presente investigación.

\section{Sociedad, cultura y juegos de suerte y azar}

Se encontraron seis investigaciones que abordan el tema de los juegos de suerte y azar en clave de los efectos que producen en la sociedad y en los sujetos que los practican, o lo hacen entendiendo el juego como un aspecto imbricado en la sociedad. Los estudios, además, plantean recomendaciones y claves de prevención en cuanto a los efectos de los juegos en los recursos para la salud.

De esta manera, se tiene que en el texto Reflexiones sobre los juegos de azar en la sociedad contemporánea: hacia una biografía del riesgo (Vacchiano y Mejía, 2017) se abordan los juegos de suerte y azar desde una perspectiva culturalista, con un acercamiento a partir de lo que se produce en las personas que los consumen de manera cotidiana, para trascender el concepto de ludopatía y abordar la noción de riesgo. Un asunto pertinente que se plantea en él para la presente investigación tiene que ver con cuál es el lugar de estos juegos en la cotidianidad y por qué han tenido una posición en la modernidad, particularmente en los últimos 20 años; preguntas que apuntan al significado del juego en la vida de los antioqueños, entendiendo que "los juegos permiten la expresión de las habilidades personales (lógicas, histriónicas o morales), determinando algunas dinámicas inherentes a la construcción de 
la reputación y/o estatus social en grupos determinados" (Vacchiano y Mejía, 2017, p. 41). En el mismo sentido que plantean estos autores sobre el consumo de riesgo, está la contribución de García, Buil y Solé (2016), quienes describen las dificultades que se presentan en los jóvenes a partir de lo que sucede con los juegos de azar online, promueven el concepto de "juego responsable" y lo abordan desde el tema de consumos de riesgo.

Por su parte, los textos Los juegos de suerte y azar como problema en la investigación social en México: Balance preliminar y perspectivas (Echeverría et al., 2011); Juventud y juegos de azar. Una visión general del juego en los jóvenes (Pérez et al., 2018), y Análisis teórico de los juegos de azar como construcción (Manrique, 2010) abordan los juegos de suerte y azar desde una dimensión social y cultural, buscando la comprensión de estas prácticas en un marco contextual y subjetivo. En México, Echeverría et al. (2011) elaboran un estado de la cuestión sobre los juegos de suerte y azar en Yucatán hallan elementos claves para el estudio de este fenómeno, y advierten que el tema más estudiado sobre los juegos está relacionado con la ludopatía y que, particularmente, hay vacíos de estudios que tengan una perspectiva social; sin embargo, se pueden encontrar investigaciones que referencian las consecuencias del juego relacionados con la familia o en clave del tema de las adicciones.

Esta investigación coincide con algunos elementos que desarrolla Manrique Fragoso (2010), como aquel que plantea que el fenómeno de los juegos de suerte y azar se debe leer desde una construcción sociológica y cultural:

El problema no reside en la existencia de los juegos de azar, sino en la forma en que las sociedades hacen de estos una costumbre, basándose en los actuales ideales de crecimiento establecidos desde la economía. El azar no es un resorte impersonal al individuo, sino que se concede valor a toda señal que pueda ofrecer el entorno y los fenómenos que le constituyen para creer que la fortuna está de su lado o no. (Manrique Fragoso, 2010, p. 102)

Este análisis entra en tensión con algunos elementos del planteamiento de los españoles Pérez et al. (2018), quienes abordan dos aspectos muy importantes que se situaron en la presente investigación: por un lado, caracterizan quiénes son los que consumen los juegos de suerte y azar, siendo los jóvenes el objeto 
de su investigación y, a su vez, cómo lo consumen y qué efectos tiene tanto a nivel individual como en otras dimensiones. También analizan los juegos desde la economía y el marketing, dimensiones que propenden por construir acciones de prevención para evitar las dificultades que se tejen en torno a los juegos de suerte y azar.

\section{Juegos de suerte y azar: impuestos y legalidad}

En este apartado se analizaron las investigaciones que trataron el tema de los juegos de suerte y azar desde el aspecto normativo o tributario y que, en esa medida, hicieran referencia a la ilegalidad. Se presentan, entonces, las investigaciones por orden cronológico: el año 2001, Figueredo Morales, desarrolla su tesis El monopolio de los juegos de suerte y azar y su incidencia en la hacienda local, la cual desarrolla un recorrido investigativo sobre la normatividad asociada al monopolio y los impuestos sobre este, analizando la Ley 643, promulgada en dicho año. Esta tesis permite situar la presente investigación en la estructura para el funcionamiento del monopolio desde dicha ley, teniendo en cuenta que, de acuerdo al autor, dicha estructura:

... no solo garantiza un sistema administrativo y operativo con mejores [estándares] de eficiencia en la explotación del mercado de los juegos de suerte y azar, sino que a la vez le permite la obtención y aprovechamiento de los recursos derivados del ejercicio directo de las actividades monopolizadas, es decir de recursos asociados a los derechos de explotación pactados con los terceros que debidamente autorizados, operen juegos de suerte y azar. Todo ello para el logro del fin último del monopolio constitucional, consistente en el financiamiento de los servicios de salud. (Figueredo Morales, 2001, p. 64)

En ese sentido, para el 2003, la Empresa Territorial para la Salud (en adelante Etesa), presentó el informe de su investigación Cuatro estudios sobre juegos de suerte y azar en Colombia. En él se desarrolla el tema de la incidencia de la desconfianza en el apostador colombiano, que es un interesante asunto en cuanto al tema de la ilegalidad, particularmente, respecto al chance, advirtiendo que: 
... el chance ha sido víctima de manipulaciones, generando desconfianza en el apostador; este es el caso del "chance blanco" u operación del juego en talonarios no oficiales, la cual es una actividad efectuada, generalmente, por agentes a las empresas concesionarias del juego; cuando se ejecuta de esta manera, la infracción es evasión... el "chance clonado" es una falsificación del talonario de chance, procurando una copia más fiel que la original... es básicamente una forma de elusión. (Etesa, 2003, p. 12)

Este estudio le aporta elementos a la presente investigación en la medida en que permite identificar dos prácticas de ilegalidad que se relacionan con el pago de impuestos. Por su parte, el segundo y tercer estudio, presentados por Etesa, hacen una especie de caracterización en la que dejan ver quiénes son las personas que juegan, estableciendo una relación con el estrato y el tipo de juego que practican, en donde se deja en evidencia la preferencia por el chance, de manera general en todos los estratos (Etesa, 2003, pp. 1641), y finaliza con un estudio que propone juegos novedosos que se podrían implementar para fortalecer el mercado.

En el texto del Observatorio Legislativo, Juegos de suerte y azar (Instituto de Ciencias Política Hernán Echavarría Olózaga, 2009), se aborda, de manera muy concreta, cómo se operativiza el monopolio de juegos de suerte y azar, cuáles son las instituciones responsables de la explotación del mismo y cuál es la destinación. Este texto emerge a partir de la modificación a la Ley 643 de 2001 y plantea cinco aspectos: la protección social de loterías y colocadores, apuestas hípicas, la operación de nuevos juegos, la asociación para la operación de loterías y el control de ilegalidad; todos ellos de interés para la presente investigación, pues dice que, para la fecha:

... se propone extender la función de vigilancia y control sobre los juegos de suerte y azar -que hoy se encuentra en cabeza de las autoridades de policía y los organismos de control- a las entidades que explotan y administran el monopolio rentístico. Esto implicaría otorgarles facultades para suspender juegos no autorizados y denunciar prácticas prohibidas; requerir a operadores de juegos ilegales y a terceros para que rindan testimonios y declaraciones; solicitar el 
apoyo de autoridades públicas para efectuar las diligencias de cierre de establecimientos o juegos cuando se requiera, y tomar las medidas necesarias para garantizar la conservación de la prueba sobre los actos ilícitos o prohibidos. (Instituto de Ciencias Políticas Hernán Echavarría Olózaga, 2009, p. 2)

Igualmente, se tiene el trabajo de grado Identificación de estilos gerenciales administrativos vigentes y necesidades derivadas de formación en las empresas del sector servicios subsector juegos de azar en el Área Metropolitana centrooccidente (Céspedes y Osorio, 2010), que es una investigación de carácter descriptivo en la que se ubican algunos elementos vinculados con los estilos gerenciales de las entidades relacionadas con juegos de suerte y azar, y se aborda la estructura organizativa desde la promulgación de la Ley 643 del 2001. Si bien la investigación no tiene una relación directa con las categorías que se usaron para la presente investigación, es importante en la medida que es posible reconocer algunas formas de organización y gerencia respecto a los juegos de suerte y azar.

La investigación de la Universidad Icesi, con el texto Concesión del monopolio de juegos de apuestas y azar en el Valle del Cauca, desarrolla un estudio estadístico que tiene que ver con la proyección sobre la venta del chance, considerando que, para dicho territorio es el juego de suerte y azar más popular. En este estudio se llega a una conclusión muy interesante en relación a las proyecciones de ventas y la ilegalidad en dicho juego, en la que se propone un tipo de análisis estadístico particular para cuando se quieran realizar este tipo de estudios:

... en el estudio se ha encontrado que hay una proporción de ilegalidad en el juego relativamente alta... Toda esta información hace que el grupo se reafirme en su posición de proponer la mediana como medida de tendencia central relevante para la determinación de las ventas brutas de chance en los próximos cinco años. (Alonso y Gallego, 2010, p. 222)

A su vez, Ana María Vega (2015) expone en su tesis de maestría los problemas alrededor del recaudo de los derechos de explotación en el monopolio rentístico de los juegos de suerte y azar; además, desarrolla algunos apartados 
sobre el marco normativo y las entidades asociadas a este monopolio y, particularmente, elabora un capítulo sobre los problemas alrededor del recaudo en el que expone dos asuntos necesarios para la comprensión de la ilegalidad: por un lado, la función administrativa y, por otro, la corrupción en el sector de los juegos de suerte y azar. En este texto, Vega (2015) se planta que una de las dificultades a nivel nacional con los juegos de suerte y azar tiene que ver con la capacidad administrativa, considerando que se han dado tres intentos de administración de este monopolio. Igualmente, plantea el tema de la corrupción como una problemática inherente a los juegos, en la que, en palabras de la autora, "el fenómeno de la corrupción no sólo se presenta por parte de los Operadores sino también existe en los funcionarios de la Entidad" (Vega, 2015, p. 49). Uno de los vacíos que se encuentra en esta investigación es que entre las problemáticas que evidencia no plantea con claridad la ilegalidad que se efectúa por fuera de la propia empresa y que está asociada con prácticas tradicionales o comunitarias.

En clave de lo que viene abordando Vega (2015), Morales Amado, Arévalo Díaz y Díaz Téllez (2016), abordan su trabajo alrededor de los impuestos sobre el monopolio de juegos de suerte y azar, revisando la norma sobre los mismos, que da como resultado un análisis alrededor de la contribución de la explotación de los juegos para Bogotá. Igualmente, describe los impuestos, tasas y contribuciones a los juegos de suerte y azar (p. 40) y aborda los delitos contra el monopolio rentístico y las facultades de fiscalización (p. 59), lo cual, para la presente investigación sirvió para situarla en un marco normativo, tanto sobre impuestos como sobre delitos frente a la ilegalidad en una ciudad como Bogotá, que podría ser un escenario de referencia para la experiencia antioqueña.

Para finalizar este apartado, se tiene una investigación muy importante como antecedente, es el trabajo que desarrolló Fedesarrollo en el año 2018, titulado Caracterización y estimación del mercado ilegal de juegos de suerte y azar en Colombia. En esta investigación los autores hacen todo un ejercicio juicioso sobre el mercado ilegal en los juegos de suerte y azar, y proponen tres razones para entender la presencia de la ilegalidad en dicho mercado: 
La primera, es que su naturaleza de monopolio administrado por el Estado, con una carga impositiva importante, hace que los ilegales se interesen por participar en el mercado de [juegos de suerte y azar] JSA pues les permite ofrecer mejores premios a los jugadores. La segunda, es el alcance limitado de las políticas de control por parte de las entidades competentes. Si bien hay acciones importantes y persistentes desde Coljuegos para el control de la ilegalidad, los recursos destinados al control son limitados y en los territorios los esfuerzos de apoyo son disímiles. La tercera, son los incentivos que se generan por la carga impositiva que tiene el sector formal de JSA. (Gonzalo et al., 2018, p. 34)

En este estudio se deja ver una mixtura de métodos: por un lado, la estimación por cuantitativa en relación al mercado legal y el ilegal y, por otro, un análisis cualitativo sobre la tipología de juegos y el territorio donde se practican.

\section{Proyecto de investigación}

Esta investigación, esta investigación se enmarcó en un convenio entre el Tecnológico de Antioquia y la Lotería de Medellín; previo a este se desarrollaron otros procesos investigativos de los que emergieron productos que se consideran antecedentes para la presente entrega.

El libro El control integral a las rentas ilícitas, de Gómez et al. (2017) y el artículo "La cultura de la legalidad como un ejercicio de buenas prácticas" (Usma y Zapata, 2017), son dos de ellos, en los cuales se consignan los resultados del proceso de investigación del año 2016, cuando se estaba iniciando la sistematización. De manera general, ambos textos abordan cinco rentas priorizadas por el departamento que son altamente susceptibles a la ilegalidad. En ellos se analizan los juegos de suerte y azar desde tres aspectos: por un lado, desde la explicación sobre qué es el monopolio de juegos de suerte y azar —en su momento liderado por la Beneficencia de Antioquia (Benedán) -; por otro, sobre cuáles son los fraudes más recurrentes que se identifican allí y, además, se enuncian los riesgos que trae la ilegalidad en dicho monopolio. Un aspecto importante por considerar son algunos aspectos que se señalan como buenas prácticas en el marco del abordaje al monopolio: 
1. Conocer los riesgos que puede generar el exceso de los juegos de suerte y azar en la salud mental, para así, evitarlos. 2. De reconocer irregularidades en los juegos de suerte y azar denunciar a la DIAN sobre ellas. 3. Comprar el chance electrónico solo por medio de la entidad autorizada, en este caso la empresa GANA. 4. Disminuir la modalidad de chance manual con la no compra. 5. Evitar la participación o promoción de rifas no autorizadas o reguladas por BENEDAN. 6. Apoyar la lotería local con la compra de la Lotería de Medellín. 7. Revisar los billetes de lotería para evitar la compra de billetes falsos o adulterados. (Gómez et al., 2017, p. 118)

Bajo ese marco, también se diseñó una cartilla que sirvió como material pedagógico, que se pudiera replicar en la comunidad y que permitiera identificar algunas acciones de ilegalidad (figura 1 ).
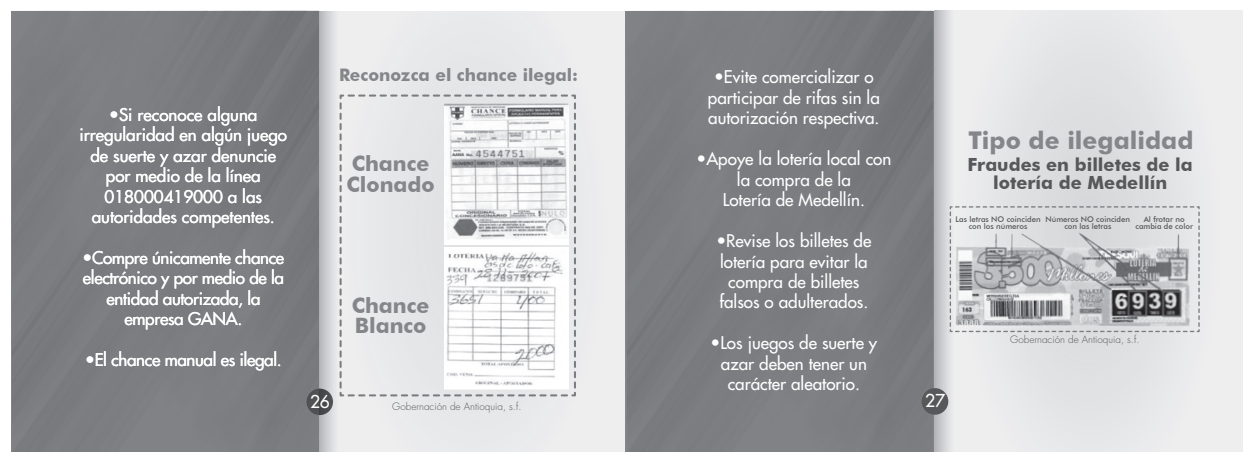

Figura 1. Cartilla sobre pedagogía contra la ilegalidad.

Imagen tomada de Antioquia gana por las buenas (Gómez et al., 2017, pp. 28 y 29).

Por su parte, el capítulo del libro "La cultura de la legalidad en las rentas del departamento de Antioquia como un ejercicio de buenas prácticas desde las acciones comunitarias" (Usma y Zapata, 2018), es una reflexión sobre cómo el ejercicio de buenas prácticas en las rentas departamentales -incluyendo el monopolio de juegos de suerte y azar- debe estar vinculado a las prácticas comunitarias, entendiendo que, desde él, se podrían establecer acciones de innovación, incidencia pública y social, diferenciación y replicabilidad y sostenibilidad más duraderas en el tiempo. De esta manera, plantea la 
importancia de que "en este escenario se puede reconocer que para construir una cultura de la legalidad es necesario otorgar reconocimiento a los actores que están inmersos en el proceso y cómo éstos se vinculan en un contexto sociocultural definido" (Usma y Zapata, 2018, p. 447).

Asimismo, en vía y consonancia con el anterior texto, el libro Las buenas prácticas de ilegalidad: instituciones responsables (Gómez, Usma, Zapata, Echavarría y Ceballos, 2019) -al igual que el anterior- se habla de la importancia de comprender cuál es el lugar de los distintos actores en el fortalecimiento de la legalidad, se tiene en cuenta la participación en los procesos institucionales como una dimensión central y se reconoce la importancia del diálogo institución-comunidad:

El componente de participación se articula con el proceso de capacitación y sensibilización en el que se vinculan tres actores: La comunidad, que se particulariza en los comerciantes y distribuidores; las personas que tienen una relación directa con cada una de las rentas, y las instituciones gubernamentales, tanto las que requieren más formación en estos temas como las que son responsables de esa capacitación. En este caso, al fomentar la participación ciudadana se está reconociendo la importancia de que la comunidad tenga conocimiento sobre las rentas con las que tiene relación, y que estas acciones se puedan replicar en términos de buenas prácticas comunitarias. (Gómez et al., 2019, p. 52)

De esta forma, se entiende que el tema de los juegos de suerte y azar está en un marco institucional y legal que requiere ser revisado constantemente desde un marco contextual y coyuntural para que se puedan realizar lecturas concretas y ubicadas sobre la situación, y se puedan plantear posibles intervenciones.

\section{Marco conceptual}

Las consideraciones teóricas aquí presentadas tienen relación con los objetivos que dieron lugar a la investigación para brindarle al lector elementos potentes para la lectura e interpretación de los resultados expuestos más adelante. Se presentan, entonces, tres conceptos claves: Los juegos de suerte 
y azar, como monopolio del departamento, pero ahondando en su análisis conceptual teórico; la ilegalidad, concepto trasversal en todo el desarrollo de este texto, y el concepto de defraudación, que tiene relación directa con la evasión de impuestos - práctica de ilegalidad reiterativa y directa con la renta en mención-.

\section{Juegos de suerte y Azar}

Los juegos de suerte y azar son conocidos como uno de los monopolios rentísticos que aporta recursos al departamento de Antioquia a través del recaudo del impuesto a la financiación de un determinado sector. Sin embargo, abordar el concepto como tal requiere una revisión teórica conceptual que permita ubicar sus características con las prácticas que se desarrollan en la región. Siendo así, los juegos de suertey azar tienen diferentes connotaciones respecto a su desarrollo histórico y su concepción dentro de las comunidades. Éstos se conciben de forma filosófica, matemática, cultural, social y normativa. Desde cada una de esas perspectivas, se puede evidenciar que existe una relación inherente entre el juego de azar y el sujeto que lo juega, llevando más allá de la acción misma los elementos que ejerce dentro del desarrollo social.

El juego tiene una relación directa con lo que se refiere a lo desconocido, ya que no existe intervención que se pueda ejercer sobre los resultados. Aunque existe intencionalidad respecto al futuro y la esperanza de efecto sobre una acción, el juego se convierte, al fin y al cabo, en la necesidad de repetición que el ser humano experimenta. El sentido de la repetición está en el anhelo de dominio sobre lo repetido.

Desde la perspectiva filosófica, la noción del juego se puede analizar a partir de varias generalidades: lo infantil, la diversión, la lúdica y la estética. Como lo expresa el autor Padró (2015): "el juego permite así una abstracción de una serie de elementos que fuera de él no se nos aparecen aislados o individualizados" (p. 232). Se puede decir que el juego en la filosofía se estudia desde "la analogía posible entre el juego y el objeto de estudio; el paradigma del juego permite estudiar, como ámbitos de excepción, distintas prácticas culturales en aquello que tienen en común, en aquello que las configura como objeto de estudio" (Padró, 2015, p. 232). 
En la misma vía, la perspectiva matemática del juego de azar se generaliza sobre el objeto de estudio y el sujeto que realiza la acción. En efecto, es plausible afirmar que toda práctica de azar se orienta hacia el futuro o, precisamente, a un conjunto de posibilidades futuras (Giddens, 1999; Vacchiano y Mejía, 2017, p. 84). El juego se puede observar como "el ejercicio de un sujeto que pretende dominar la lógica del azar mediante la repetición, propia del juego de cara y cruz" (Padró, 2015, p. 235); sin embargo, desde esta perspectiva, se podría decir que la importancia de la ejecución del juego recae sobre las posibilidades probabilísticas de los resultados, ya que la estadística permite "proponer modelos para los fenómenos aleatorios (como los juegos de suerte y azar) y estudiar sus consecuencias lógicas" (Vega, 2002, p. 54).

Por otro lado, con el paso del tiempo, los juegos de azar se empiezan a estudiar específicamente sobre el impacto en la salud debido a las consecuencias de la repetición excesiva del juego. Más allá de este campo de estudio, es importante abordar el juego de suerte y azar desde perspectivas culturales y sociales que decantan en la normatividad y la importancia del impuesto sobre dicha actividad. En efecto, con el impacto de los medios de comunicación actual, la industria del juego se ha convertido en un fenómeno de entretenimiento masivo (Reith, 2002), cuya incorporación en el sistema social es hoy en día "legitimada" e "institucionalizada" después de siglos de represión legislativa (Vacchiano y Mejía, 2017, p. 84).

Actualmente, existen numerosos juegos que están organizados según reglamentaciones institucionales. En la modernidad se identifican dos categorías: Juegos de habilidades y Juegos de chance. La primera involucra las capacidades y la experiencia del jugador y la segunda se refiere a la oportunidad al azar de ganar un juego.

Dentro de estos dos grandes grupos se concretan distintas tipologías de juegos (en la vertiente online u offline): apuestas deportivas, loterías instantáneas, póker, slot machine, y así sucesivamente. Si bien cada juego lleva implícitamente a experiencias específicas, en todas estas tipologías la exaltación de la "toma de riesgos" se configura como la característica principal del acto de jugar. (Vacchiano y Mejía, 2017, pp. 85-86) 
Por último, a la luz de la perspectiva normativa, los juegos de suerte y azar se constituyen como fuente de ingresos para la financiación de aspectos y necesidades específicas de índole social a través de la Ley 643 de 2001, donde se fijan como un monopolio rentístico de Colombia y, a partir de la Ordenanza 29 de 2017, se definen como:

Aquellos en los cuales, según reglas predeterminadas por la ley y el reglamento, una persona, que actúa en calidad de jugador, efectúa una apuesta o paga por el derecho a participar, a otra persona que actúa en calidad de operador, quien le ofrece a cambio un premio, en dinero o en especie, el cual ganará si acierta, dados los resultados del juego, no siendo este previsible con certeza, por estar determinado por la suerte, por el azar o por la casualidad. (Asamblea Departamental de Antioquia, 2017, art. 22)

Los juegos de suerte y azar se pueden observar desde diferentes elementos, sin embargo, esbozar un concepto general del término puede parecer confuso si se hace en relación con cada una de las perspectivas abordadas. Aun así, en esta investigación se puede afirmar que estas actividades se desarrollan alrededor de la posibilidad y la casualidad de un hecho esperado, y que los sujetos activos en tal acción están inmersos en características filosóficas, matemáticas, culturales, sociales y normativas a partir del deseo de la repetición, la probabilidad del objeto (premio), el fenómeno que se desarrolla en el entorno y las responsabilidades de ley.

\section{llegalidad}

A partir de los elementos identificados en el planteamiento del problema, se puede decir que la ilegalidad es una categoría que reúne formas de manifestación que se pueden referir a los actos violatorios de ley y, también, a las particularidades culturales en las que seencuentran inmersos los individuos que incumplen o desconocen la norma. En ese sentido, es importante abordar en primer lugar el concepto de legalidad, el cual permitirá identificar cuándo el comportamiento del individuo se convierte en incumplimiento, es decir, en una afectación de ilegalidad. 
Así pues, desde una visión legal y normativa se podría plantear que "la legalidad es un principio de la vida sociopolítica, un método de dirección de la sociedad y ese método o principio se realiza a través del cumplimiento de la ley" (Delgado, 2012, p. 6). Es conocida como representación del derecho, lo que significa que existe un grupo de normas y la responsabilidad que tienen los jugadores de acatarlas. El principio de legalidad tiene una permanente y renovada función práctica que cumplir (Legaz, 1958, p. 21), pero cuando se observa desde la validez de los actos es necesario reconocer las identidades individuales y colectivas respecto a la legitimidad de la institución con respecto al desarrollo de las prácticas sociales. En ese sentido, la ilegalidad se observa desde lo que es contrario para ley, pero también es necesario que se abarque el trasfondo de un acto de incumplimiento, ya que para fortalecer una cultura de legalidad dentro de las comunidades se debe superponer una relación entre las prácticas y las particulares del espacio en el que se desarrollan.

Se manifiesta que las afectaciones de las acciones de ilegalidad pasan por la construcción de sentido de comunidad, de pertenencia, de reconocimiento de la historia social e identitaria, que los une como sujetos sociales y en relación (Montero, 2007, citado en Zapata y Usma, 2018, p. 219). A partir de allí, el incumplimiento de las normas recae entonces en las creencias que se forjaron con el tiempo sobre credibilidad institucional y la forma en la que el tejido social se construyó.

En Latinoamérica, la ilegalidad, como un acto histórico, se reconoce como una cultura del incumplimiento derivada de una identidad colectiva que justifica el incumplimiento en los imaginarios sociales y políticos. Esta cultura, según Fariñas, “... no es un problema nuevo, pero sí poco analizado, teniendo en cuenta que constituye un factor determinante del infra desarrollo democrático de las sociedades y, en especial, de las latinoamericanas" (2010, p. 185).

En este sentido, y en relación con lo planteado anteriormente, el contexto y el espacio proponen problemas y mecanismos a la medida. Para cada comunidad existen elementos diferenciadores y concepciones diferentes sobre incumplimiento de ley. De acuerdo con el histórico colectivo del departamento de Antioquia, la ilegalidad ha estado latente en el desarrollo de 
las generaciones (Gómez et al., 2019, p. 28), no solo desde el incumplimiento de ley por parte de las comunidades, sino también desde los problemas de acción colectiva que involucran escándalos históricos relacionados con fraude en el país de Colombia. De esta manera, los individuos tienen la confianza individual de que se podrá evitar la sanción de la ley cuando uno "se ha saltado la cola” para obtener ciertas ventajas personales (López, 2014, p. 64). Es decir, que las personas se pueden sentir con el derecho de trasgredir la ley porque el "otro" - entendido como gobierno, empresa, comunidad y/o individuorealizó un acto ilegal. De esta manera,

... la gente puede aceptar como natural el incumplimiento de las normas, por ser parte de la vida normal y/o puede sentirse autorizada a buscar beneficios para sí misma, más allá de la legalidad, implicándose en actos ilegales, corruptos e ineficientes, generándose una trampa social. (Bardhan, 2005, como se citó en Delgado, 2012, p. 89)

Sin embargo, que esta perspectiva cultural explique el incumplimiento de ley no debe significar que la ilegalidad deba ser un acto justificado y aceptado socialmente.

Es muy importante destacar que la conexión entre percepción de ilegalidad y expectativas de bajo respeto a la legalidad por parte de los otros no tiene por qué conducir inmediatamente a la aceptación generalizada de la corrupción o el fraude. Ni tampoco a la implicación personal en actos ilegales o fraudulentos. Simplemente, genera unos incentivos tan poderosos entre los actores que pueden hacer que, una parte de la población, ante el dilema de cumplir la ley y ser perjudicado o saltarse la ley y beneficiarse, opte por lo segundo, agrediendo a esa parte inteligentemente altruista del ser humano. (Villoria y Jiménez, 2014, pp. 91-92)

Esas prácticas, entonces, pueden ser resarcidas desde enfoques estructurales -y también desde la construcción de conciencia ética individual y colectiva - a partir de un fortalecimiento de cultura de legalidad donde se logren relacionar las afectaciones de la ilegalidad que van más allá del aspecto económico, e involucran el desarrollo social de las comunidades. Por lo tanto, que se pueda lograr 
la capacidad de reproducir en la propia cabeza las razones por las cuales debemos respetar las normas así no exista riesgo de detección. Este mecanismo ético existe, pero requiere de altos niveles de educación moral y capacidad de representación de los derechos de los otros y de los intereses colectivos. (López, 2014, p. 67)

En la estrategia que desarrolló la Lotería de Medellín se pueden identificar las prácticas de ilegalidad relacionadas con el monopolio, y se evidencian también las formas de incumplir la ley, que no necesariamente -como ya se abordó- tienen la intención de agresión, perjuicio o corrupción.

\section{Defraudación}

El concepto defraudación es importante para las rentas porque afecta la inversión social. Este concepto se relaciona directamente con el área de tributación y, normalmente, con el concepto de evasión fiscal; sin embargo, incurrir en la acción de no pagar un impuesto no solo es una actividad que se considera delito. En tal sentido, según Rezzoagli (2009), la defraudación fiscal es

... una figura de daño patrimonial, en la que la materialidad de la acción consiste en omitir - total o parcialmente- sumas adeudadas por los sujetos o particulares en concepto de tributos, mediante el aprovechamiento de errores o utilización de maniobras engañosas. (p. 3)

Por otro lado, desde la administración tributaria se presenta un enfoque relacionado con la perspectiva fiscal abordada anteriormente; sin embargo, hay unas consideraciones sobre el término. Colina lo explica así:

Se caracterizará por la "defraudación" de las expectativas que se esperaban del contribuyente en cuanto al cumplimiento de sus obligaciones para con laAdministración Tributaria, independientemente del ámbito de gobierno que se trate. El verbo rector del tipo "defraudar" lo entiende la mayoría de la doctrina como el perjuicio patrimonial causado mediante engaño. (Como se cita en Sharlot, 2016, p. 58)

La defraudación fiscal posee conductas correlacionadas con el engaño; sin embargo, si al ejecutarse la acción no presenta una consecuencia específica, 
no se consideraría delito. En consecuencia, no existirá defraudación en el caso de que la obligación que se pretenda evadir sea de una diferente a aquellas prestaciones pecuniarias que el Estado exige en ejercicio de su poder (Barrera y Hessdorfer, 2016, pp. 16 y 17).

Este término tiene entonces una relación entre la acción y el beneficio adquirido a través del delito, donde es importante reconocer los elementos constitutivos de defraudación fiscal para entender desde qué naturaleza se sitúa el concepto. A continuación, se presentan algunos: a) Engaño o aprovechamiento de errores; b) omisión de pagar un tributo de manera total o parcial; c) consecución de un beneficio indebido; d) nexo de causalidad entre el engaño y el no pago del tributo u obtención del beneficio indebido (Rezzoagli, 2009. p. 3).

Siendo así, se puede retomar la relación entre defraudación y evasión, en la cual, siempre que exista, la primera poseerá la segunda, "mientras que cuando exista evasión no necesariamente habrá defraudación fiscal, dado que muchas veces pueden evadirse impuestos por culpa o mera negligencia, esto es, sin intencionalidad alguna" (Rezzoagli, 2009, p. 3).

La defraudación afecta de manera importante a las instituciones públicas y, a la vez, el desarrollo de sus proyectos. El resultado de la defraudación es la elusión del pago del tributo, siendo la producción del perjuicio patrimonial una condición objetiva de punibilidad (Choclán, 2016, p. 81). Estas pérdidas económicas generan un perjuicio futuro directamente, y aplica igualmente para las rentas departamentales, por lo tanto, "resulta necesario establecer normas sustantivas específicas para las deudas tributarias derivadas de la forma más grave de defraudación tributaria, como es el delito contra la Hacienda Pública" (Choclán, 2016, p. 23).

Para establecer normas que fortalezcan las normas es importante incentivar acciones entre los contribuyentes para generar el pago oportuno y consciente, y así, lograr que las destinaciones específicas reciban las rentas oportunamente.

La Administración tributaria, como institución dotada de medios materiales y humanos para la realización de actividades encomendadas a la Hacienda Pública y hacer efectivo el sistema tributario, se propone 
como uno de los objetivos prioritarios al conseguir de sus ciudadanos, los contribuyentes, el mayor grado de cumplimiento voluntario de las obligaciones fiscales. (Prieto, 1994, p. 222)

\section{Marco metodológico}

Para dar cumplimiento a los objetivos de la investigación se estableció una ruta metodológica que permitió hacer un recorrido por cada uno de los objetivos para darle una lectura integral al fenómeno de la ilegalidad en los juegos de suerte y azar y su efecto en el herario público. De manera general, esta investigación se realizó a través de un diseño predominantemente cualitativo, en el cual se utilizó el análisis descriptivo de la información estadística y la encuesta, propia de la investigación cuantitativa, para aportar datos que permitieran tener una comprensión de las acciones de la estrategia. Atendiendo a Tonon de Toscano (2013), la importancia de las mixturas reside en la integración del análisis, comprendiendo que:

Los métodos mixtos son una forma de investigación que implica mucho más que la simple recolección de datos cuantitativos y cualitativos, indica que los datos pueden ser integrados, relacionados y/o mixturados en alguna etapa del proceso (Creswell et al., 2004, p. 7). La compleja realidad social en la cual nos toca vivir y trabajar, requiere para su estudio y abordaje no solo utilizar la triangulación de métodos, sino que lograr la complementación y la integración de los mismos. (Tonon de Toscano, 2013, p. 8)

En este sentido, para el proceso de recolección y análisis de información hubo una mixtura de técnicas, algunas muy propias de la investigación cualitativa, como la entrevista semiestructurada y la revisión documental, y otras, como la encuesta y el análisis de datos estadísticos, más usadas en la investigación cuantitativa. Para ello, entonces, se rescata el método interpretativo de los datos cualitativos, teniendo en cuenta que éste permite realizar un análisis situado de la realidad que se está explorando en este caso los juegos de suerte y azar en el departamento de Antioquia. Así pues, se utiliza un método interpretativo porque: 
Intenta comprender la realidad, considera que el conocimiento no es neutral. Es relativo a los significados de los sujetos en interacción mutua y tiene pleno sentido en la cultura y en las peculiaridades de la cotidianidad del fenómeno educativo. En este sentido, tiene lógica. (Ricoy, 2006, p. 17)

De esta manera, como se dijo anteriormente, el método permite situar el fenómeno de la ilegalidad en los juegos de suerte y azar desde su dimensión sociocultural y contextual, además posibilita trascender de un análisis estadístico meramente descriptivo a reconocer categorías de análisis cualitativas que favorezcan la comprensión de la realidad desde la perspectiva de los territorios y sus actores. Para mayor comprensión se usaron las técnicas cualitativas, para aportar, principalmente, al primer y tercer objetivo de la investigación; es decir, las entrevistas semiestructuradas, la revisión de fuentes documentales y algunos elementos propios de la encuesta arrojaron datos cualitativos que permitieron realizar procesos de cruce y análisis categorial para dar cuenta de los resultados que aportaran dichos objetivos. Por su parte, el objetivo dos se abordó principalmente con datos estadísticos suministrados por el grupo de operativos de la estrategia.

A continuación, se describen brevemente las técnicas usadas y se detalla la estrategia estadística empleada para el análisis de datos.

\section{Técnicas de recolección de información}

La técnica de análisis de documentos se desarrolla a través del instrumento de matrices bibliográficas, de coherencia e intertextuales; en este sentido, con esta técnica:

Los métodos de recuperación, entre los que se cuenta el análisis documental, responden a tres necesidades informativas de los usuarios, en primer lugar, conocer lo que otros pares científicos han hecho o están realizando en un campo específico; en segundo lugar, conocer segmentos específicos de información de algún documento en particular; y, por último, conocer la totalidad de información relevante que exista sobre un tema específico. (Peña y Pirela, 2007, p. 58) 
De manera que, a partir de esta técnica, se pudo recoger, caracterizar, describir, codificar y categorizar la información, de tal forma que se pudieran reconocer los elementos teóricos claves sobre el impacto socioeconómico en relación a categorías como la ilegalidad y salud, para fundamentar contextual y territorialmente el fenómeno de juegos de suerte y azar en función del impacto socioeconómico. Por otro lado, la entrevista semiestructurada fue usada como insumo para acercarse a la realidad de los actores desde su propia experiencia, de tal forma que permitirá adentrarse en las particularidades del fenómeno de la ilegalidad en los juegos de suerte y azar en el territorio de Antioquia. Se tuvo en cuenta que las entrevistas semiestructuradas:

Presentan un grado mayor de flexibilidad que las estructuradas, debido a que parten de preguntas planeadas, que pueden ajustarse a los entrevistados. Su ventaja es la posibilidad de adaptarse a los sujetos con enormes posibilidades para motivar al interlocutor, aclarar términos, identificar ambigüedades y reducir formalismos. (Díaz-Bravo et al., 2013, p. 163)

Por su parte, la encuesta, como una técnica que tradicionalmente se usa en investigación cuantitativa, también favorece el análisis desde una perspectiva cualitativa, teniendo en cuenta que puede ser útil para el estudio de la perspectiva de los actores sobre la realidad social (Dalle et al., 2005, p. 50). A su vez, se utilizó una matriz para el análisis estadístico que arrojó información cuantitativa en relación a la implementación de la estrategia sobre la ilegalidad en los juegos de suerte y azar. Así pues, la encuesta aplicada permitió recoger fuentes orales, siendo aplicada a secretarios de hacienda y otros funcionarios de 112 municipios del departamento de Antioquia, entre el año 2017 y 2018. Igualmente, se recogió información escrita de orden documental, como matrices de recolección de datos para el análisis cuantitativo, informes, artículos de investigación (entre el 2005 y el 2019), libros de texto, páginas de internet, documentos oficiales e institucionales y normatividad, entre otras fuentes que aportaron al análisis de la información.

\section{Análisis de datos estadísticos}

Para el tratamiento de los datos estadísticos se aplicaron procedimientos orientados particularmente a identificar la defraudación económica en 
el monopolio de juegos de suerte y azar, a partir de las aprehensiones desarrolladas en el marco de los operativos realizados en el departamento de Antioquia. Dichos datos son los siguientes:

Análisis exploratorio. Instrumentos de recolección (ver Anexo 1) que contienen variables cualitativas y cuantitativas con las cuales se exploraron algunas características relacionadas con los juegos de azar. Fueron aplicados por el personal de la Lotería de Medellín y entregados al equipo de investigación, que luego los hizo llegar al asesor estadístico.

Análisis descriptivo. A través de software estadístico (Excel, SPSS, Statgrafic u otros) se recogieron, depuraron, tabularon y se realizaron gráficos y cálculos porcentuales para las variables cualitativas, así como cálculos de medidas estadísticas como media, mediana, moda, cuantiles, medidas de dispersión y medidas de comparación con la distribución normal estándar como el sesgo y la curtosis.

\section{Análisis particulares}

Para variables cualitativas. Utilizando tablas dinámicas en Excel, se elaboraron tablas de contingencia $2 \times 2,2 \times n$, o $n \times m$, dependiendo de las preguntas de investigación y los objetivos formulados, a los que pudieran aportar los cruces de variables elegidas. Tales tablas se presentaron solo con frecuencias absolutas, solo con porcentajes, o combinando los dos tipos de información.

\section{Para variables cuantitativas}

Análisis de correlación entre dos variables cuantitativas. Se exploraron los indicios de correlaciones entre pares de variables cuantitativas, como, por ejemplo: cantidad de aprehensiones y valor total del material incautado, cada mes y durante un año. Con la información tomada, este tipo de exploración pudo arrojar, o no, algún indicio de correlación, ya fuera lineal, exponencial, logarítmica, etc., en cuyo caso se presentaron un gráfico de dispersión, la curva de mejor ajuste, el coeficiente de correlación $(r)$ y el coeficiente de determinación $(R 2)$; y se presentó un análisis del significado de los resultados de la posible correlación, cuando esta parecía existir. 
Intervalos de confianza. El cálculo de las medidas descriptivas para variables cuantitativas permitió explorar algunas inferencias en términos de estimación de intervalos de confianza para cada una de tales variables. Este tipo de análisis no se presentó en este caso porque, aunque resultó fácil de realizar para cada variable cuantitativa, por un lado, no se contó con información de estudios anteriores en los que se hubiesen obtenido parámetros que sirvieran de referencia para establecer comparaciones pertinentes; por otro, porque no resultó práctico presentar una cantidad de intervalos de confianza sobre variables que no fueran de interés para los promotores de la investigación, o para observadores y analistas externos.

Contraste de hipótesis. Aunque no se contó con hipótesis con fundamento en variables cuantitativas para contrastar en esta investigación, los resultados obtenidos con medidas descriptivas y las tablas de contingencia arrojaron cantidades que sirven de referencia para formular hipótesis que podrían contrastarse en próximos estudios. En cada uno de los procesos estadísticos se presentan gráficos con sus correspondientes interpretaciones, se realizan análisis, se elaboran conclusiones y se hacen las recomendaciones del caso, los cuales se presentan en los siguientes capítulos. 


\section{Resultados}

Los resultados de la investigación contienen tres partes: una orientada a la revisión de un archivo de noticias, otra que hace referencia a las categorías construidas a partir de la recolección de información de las entrevistas semiestructuradas y algunos elementos de la encuesta, y una tercera que aborda el análisis estadístico que se documentó a partir de la recolección de datos cuantitativos de los grupos operativos.

A continuación, se presentan los resultados cualitativos obtenidos, los cuales tienen un apartado del archivo de noticias y otro que da cuenta del análisis de información de otras fuentes de información.

\section{Rastreo de archivo de noticias}

En la indagación de información, evidencias, testimonios y asuntos relacionados con el ejercicio de la ilegalidad en los juegos de suerte y azar en el departamento de Antioquia, fue preciso acercarse a medios de información como Teleantioquia Noticias, El Tiempo, Hora 13 Noticias, Cosmovisión Noticias, Minuto30.com, Caracol Radio, Yogonet, Elmundo.com, DiariOriente.com y RCN Radio para buscar acciones y eventos importantes en hechos registrados en los cuales se reconocen hechos ilegales por venta de chance, falsificación de lotería y otros datos que ponen en evidencia conductas que no solo tienen que ver con ilegales, sino que hay autoridades comprometidas y población afectada. También se buscaron opiniones y comentarios en torno a los hechos noticiosos que reflejaran las conductas de los actores ilegales y los procedimientos para 
enfrentar la situación. Se extrajeron 13 noticas que comentan, denuncian o informan sobre comportamientos y conductas ilegales de la población y/o sobre las intervenciones de las autoridades.

Para desarrollar esta tarea se indagó en los medios de comunicación, noticieros y prensa escrita y audiovisual, donde hubo lugar para términos de búsqueda como: "Juegos de suerte y azar ilegal", "chance ilegal", "chance falsificado", "chance manual", "lotería falsificada", "venta de chance manual", "negocios de juego ilegal", entre otros. Para realizar estas pesquisas, inicialmente se tuvo en cuenta el rango de tiempo entre 2015 y 2019; sin embargo, se retomaron noticias de años anteriores al considerar que también podrían dar cuenta de la historia de hechos ilícitos en materia de juegos de suerte y azar. Con la información obtenida se realizó un filtro que, finalmente, dio paso al desarrollo de las siguientes categorías: "Chance y Apuestas Ilegales", y "Bandas en el Negocio de las Apuestas Ilegales".

\section{Chance y apuestas ilegales}

Esta categoría tiene información sobre los hechos noticiosos relacionados con el chance ilegal. Teleantioquia Noticias (2012), brinda un informe en torno al chance ilegal en el que afirma que esta modalidad en Antioquia capta alrededor de $\$ 100.000$ millones de pesos al año. El noticiero anota lo siguiente sobre los perjuicios que causa al departamento y a la población: "Esta práctica le roba recursos a la salud del departamento, no paga impuestos y en muchas ocasiones no les responde a los apostadores" (Teleantioquia Noticias, 2012).

Por su parte, para el año 2014, se encuentra la noticia "Chance ilegal sigue jugándose en barrios y municipios paisas" (García, 2014), en la que se muestra que la práctica de venta ilegal de chance continúa presente entre la población antioqueña; el titular revela, además, que esta práctica radica en que "la modalidad del chance ilegal consiste en que es hecho por medio de talonarios manuales, donde no existen garantías para los compradores" (García, 2014, párr. 1). Asimismo, expone argumentos sobre el efecto que tiene sobre la cartera del departamento cuando dice que "Antioquia deja de percibir unos 6.000 millones de pesos al año por ventas del juego clandestino" (García, 2014). 
Igualmente, bajo esta misma categoría, en Hora 13 Noticias se informa sobre las sumas que el chance ilegal genera a las bandas, con el titular: "Diez mil millones de pesos de chance ilegal se están quedando en manos de las bandas criminales", mientrasque, en esta misma noticia, se advierte que la Beneficencia de Antioquia (hoy Lotería de Medellín), hace un llamado a la ciudadanía para que no apoyen este negocio y compre solo en los sitios autorizados" ("Diez mil millones...", 2015). Por su parte, en Cosmovisión Noticias (2015) se presenta una noticia en la que se abordan aspectos relacionados con prácticas de ilegalidad, las consecuencias de la misma y los lugares en Antioquia donde se dan con mayor frecuencia dichas acciones, al respecto advierten que:

Los principales captadores del dinero destinado a la salud y la educación serían las bandas criminales que delinquen en Antioquia y añade que esto lo hacen mediante el chance ilegal que ellos mismos manejan... la situación se estaría presentando con mayor regularidad en las subregiones del Valle de Aburrá, Bajo Cauca y Suroeste. (Cosmovisión Noticias, 2015)

Asimismo, sobre el chance ilegal, en Minuto30.com (2016), hay una nota sobre la cantidad de dinero que deja de recibir el departamento de Antioquia por cuenta del ejercicio del chance ilegal, con el titular "El chance ilegal le genera al departamento pérdidas superiores a los 90 mil millones de pesos"; anota este noticiero que esta situación tiene preocupados a diputados de Antioquia porque esos dineros debían ser destinados a la salud de los antioqueños (Minuto30, 2016). Además, en 2016, en el noticiero Hora 13 Noticias, también pasan una nota titulada "La Fiscalía ocupa bienes avaluados en más de $\$ 50.000$ millones de pesos, producto del chance ilegal", sobre un operativo en el que fueron decomisados bienes obtenidos con dineros producto del chance ilegal. La nota amplía esta información con nombres de reconocidos personajes que tienen que ver con el negocio: "directamente relacionado con alías La Gata y alias Salvatore Mancuso y lo más grave es que este negocio ilegal afecta directamente la salud de esta región del país" ("La Fiscalía ocupa...," 2016).

\section{Bandas en el negocio de las apuestas ilegales}

Acerca de las bandas y las apuestas ilegales, a través de la noticia titulada "Desarticularon banda dedicada a las apuestas ilegales", el periódico Elmundo.com (2017) da a conocer que, en el oriente del departamento, descubren una banda que 
capta dineros en cien municipios de Antioquia a través de las apuestas ilegales, que debían ser destinados a la salud de la población. De igual forma, el DiariOriente. com da cuenta de otra red dedicada a las apuestas ilegales desmantelada por las autoridades que tenía presencia en municipios del oriente; la nota dice: "En un operativo realizado por parte de la SIJIN de la Policía de Antioquia, tras un año de inteligencia, se logró la captura de 15 personas sindicadas de vender, de manera ilegal, chances y rifas en municipios del departamento" ("Autoridades desarticulan...", 2017). El diario también informa sobre el dinero que dejó de ingresar al departamento de Antioquia: "Con la actividad ilícita esta banda habría desfalcado al departamento de Antioquia en aproximadamente $\$ 150$ mil millones que serían destinados al sistema de salud" ("Autoridades desarticulan..., 2017).

Otro diario digital empresarial, dedicado a la industria del juego, Yogonet (edición latinoamericana), informó en 2018 que las operaciones de bandas ilegales, con la actividad de juegos de suerte y azar, en varios departamentos de Colombia, captan dineros que deben financiar la salud de los colombianos. Dice el diario que

En operativos de control a la actividad de juegos de suerte y azar ilegales en la ciudad de Barranquilla y cinco municipios de los departamentos de Antioquia, Valle del Cauca y Cesar, se allanaron 10 establecimientos de los que se retiraron más de mil elementos que operaban sin autorización [y se aclara que] dejan de pagar más de $\$ 1.900$ millones, dineros con los que se financia el sistema subsidiado de salud de los colombianos. (Yogonet, 2018)

Por otro lado, en el año 2018, específicamente en Antioquia, RCN Radio, hace alusión a las cantidades de dinero que dejan de ingresar al sector de la salud por cuenta de las apuestas ilegales operadas por bandas organizadas; dice en su página que "en los operativos se logró la desarticulación de bandas dedicadas a la comercialización ilegal de apuestas permanentes, la recuperación de dinero y la incautación de talonarios y bonos que iban a ser comercializados" (Pinzón, 2018); también comenta el noticiero sobre la incidencia de las bandas en la pérdida de ingresos para la salud: "las organizaciones criminales dedicadas a la venta ilegal de juegos de suerte y azar causaron en 2018 una millonaria afectación al sector de la salud, generando una pérdida aproximada a los 20 mil millones de pesos" (Pinzón, 2018). 
Del año 2019 se tuvieron en cuenta dos noticias que hacen relación al monto de dinero que captan las bandas con la práctica de los juegos de suerte y azar ilegales en detrimento de la salud: La primera, de Caracol Radio, indica que "la ilegalidad en juegos de suerte y azar mueve unos $\$ 800.000$ millones"; aclara el informe que esta cifra es "el $40 \%$ de la oferta de juegos de suerte, azar y apuestas en Colombia es ilegal" (“llegalidad en juegos...", 2019). En dicha nota se presenta al presidente de Coljuegos, Juan B. Pérez, quien dice que "esto puede representar unos $\$ 800.000$ millones que son administrados por estructuras criminales en diferentes regiones del país" ("llegalidad en juegos..., 2019). Por su parte, Teleantioquia Noticias (2019) informó que en el oriente antioqueño capturaron una banda delincuencial dedicada a estos ilícitos, y advierte que "las autoridades afirmaron que estas personas hacían parte de la banda delincuencial 'Los Yanes' que tienen injerencia en los municipios de Rionegro, Concordia, San Pedro, Frontino, Jericó, La Ceja y Girardota" ("Quince personas...", 2019). El informe se detalla con la nota titulada "Personas en diferentes subregiones al parecer distribuían billetes de lotería falsos. Esta actividad de apuesta ilegal afecta fuertemente la inversión al sector salud" ("Ilegalidad en juegos...", 2019).

De manera general, las noticias alrededor de los juegos de suerte y azar advierten sobre dos aspectos: por un lado, el efecto que tiene en los recursos de los antioqueños, los cuales van destinados la salud de la región y, por otro lado, la relación de esta práctica de ilegalidad en los juegos de suerte y azar con grupos armados o bandas delincuenciales. Igualmente, se deja ver que dos de los juegos en los que puede haber mayor ilegalidad son en el chance y las loterías; estos resultados se articulan con el análisis que se plantea a continuación.

\section{Análisis por categorías}

A partir de esta información se construyeron cuatro grandes categorías de análisis en las que se centró la atención en relación a lo que ocurre con los juegos de suerte y azar en el departamento de Antioquia. Se tiene, entonces, la categoría La Función del Estado, que hace referencia a cuál es el lugar de las instituciones públicas y, particularmente, de la Lotería de Medellín, en el control de la ilegalidad de los juegos de suerte y azar. También se abordaron 
los resultados que emergieron sobre el pago de impuestos en los juegos de suerte y azar, considerando que la estrategia se fundamenta en fortalecer el recaudo de los impuestos para la Gobernación de Antioquia. A su vez, se indagó sobre las Prácticas de llegalidad en los Juegos de Suerte y Azar, que se pueden identificar en el territorio y, para finalizar, se desarrollaron aspectos propios y de la postura comunitaria en las prácticas de ilegalidad y las consecuencias en la salud en relación con los juegos ilegales.

\section{La función del Estado: Instituciones de Antioquia}

Cuando se habla de la función del Estado en esta categoría, se hace referencia, particularmente, a aquellas instituciones que tienen relación con la estrategia de control implementada en el monopolio rentístico de juegos de suerte y azar, y a su vez se habla de la "función", porque desde este lugar se ordena, operativiza y controla todo aquello que tiene que ver con dichos juegos. Es así que, a partir del ejercicio de investigación desarrollado, se encontraron algunos códigos, temas o líneas que se plantean en este texto como una forma de contextualizar las responsabilidades estatales en el control de la ilegalidad, pero, a su vez, sobre cuáles han sido las propuestas de actuación frente a la misma.

Actuación del Estado y grupos operativos. Para la estrategia usada en el control de la ilegalidad en los juegos de suerte y azar se diseñó un plan de acción que actúa como inspección en los distintos territorios donde se ha identificado la operación de prácticas de ilegalidad que puede fortalecer el conocimiento alrededor de las acciones de legalidad de diversos actores sociales con ejercicios de sensibilización y capacitación. Vale aclarar, que esta estrategia hace parte de una acción de inversión de los recursos de los propios juegos de suerte y azar, es decir, que los recursos regresan a la comunidad en forma de ejercicios de fortalecimiento a este monopolio rentístico, posibilitando el despliegue territorial y las acciones que se desarrollan en este marco, como lo advierte una persona entrevistada:

Es bueno que sepan de dónde han salido los recursos para este contrato. Estos recursos salieron de los chances que la gente no ha reclamado; la gente tiene un año para reclamar su chance. Si yo me gané el chance, tengo un año para reclamarlo y mucha gente compra el chance, se lo 
hecha al bolsillo, lo mete a la lavadora, se le olvida, bota el papelito, lo dejó en la mesa de noche, etc. Entonces eso se bota o se pierde y la gente no lo reclama, y hay cantidad de recursos y premios sin reclamar, entonces estos recursos de este convenio son de esa plata. (E2)

Como se dijo anteriormente, en el desarrollo de esta estrategia se hicieron distintas formas de intervención en los territorios y grupos específicos que se vinculan con los juegos de suerte y azar. Para este fin, la Lotería de Medellín conformó un grupo de personas para atender las necesidades particulares que se presentan en cada municipio, considerando que las prioridades tienen que ver con las loterías ilegales y el chance manual, ya que, de acuerdo con la experiencia, estas son las prácticas más recurrentes y muestran una mayor evasión del impuesto. De tal forma que, la organización del grupo de operativos está orientada, principalmente, a controlar estas dos prácticas:

Somos 18, hay cuatro profesionales de campo; los otros son tecnólogos de campo:, la coordinadora general, el coordinador de operativos y la auxiliar operativa; nosotros en este momento, junto con el personal profesionales de campo y tecnólogos de campo, son los que van a los diferentes municipios que previamente hemos concertado con el coordinador de operativos donde él tiene conocimiento que más es rifas ilegales y venta de chance ilegal se presenta en el departamento entonces vamos dándole prioridad a ellos. (E2)

En este sentido, respecto a la información recogida, el grupo de operativos tiene varias tareas: localizar a los distintos actores sociales que tienen alguna práctica de ilegalidad, independientemente que sea un ciudadano de manera individual -que, por ejemplo, esté vendiendo chance manual o lotería-o un supermercado o empresa - que pueda estar haciendo un sorteo promocional sin autorización-. Una de las funciones del grupo de operativos tiene que ver con la identificación y localización de la práctica de ilegalidad; para ello utilizan, como estrategias, la búsqueda de vendedores en los distintos territorios y la denuncia ciudadana:

Hay varias formas de localizar los vendedores: la primera es bajo denuncias que nos llegan directamente de la Lotería de Medellín... a nosotros simplemente nos mandan esa información, nos dicen las 
características y vamos y lo hacemos; si lo encontramos hacemos la aprehensión con la policía y si lo encontramos en situación de flagrancia. La segunda [es que] los compañeros de nosotros de equipos de producción se paran en los parques, en los lugares más concurridos y hacemos una labor de observación y determinación, muy sencillo; entonces el que vende chance manual lo ofrece, entonces vos te sientas a tomarte un tinto y ahí te llegan. Eeso no pasa a más. Eso queda ahí, pero sabemos que es la persona posteriormente el grupo operativo se programa... como ya sabemos dónde están y quiénes son las personas vamos y hacemos las aprehensiones. (E1)

Se debe mencionar que en los casos en los que se halla a algún actor vendiendo chance o rifas ilegales se informa a la entidad o individuo sobre la práctica que está llevando a cabo, y en articulación con la Policía Nacional, se realiza la incautación o aprehensión correspondiente, como se señala a continuación:

Ellos van uno o dos días antes de realizar el operativo para hacer estas labores de verificación... de las personas que posiblemente son los que operan estas rentas ilícitas en los municipios; ellos van junto con el coordinador de operativo. Les hacemos conocer la información a las personas que van a operar la parte operativa en sí, es decir acompañados de la Policía Nacional, porque nosotros no podemos ir a hacerle una requisa a un ciudadano, no podemos ir a solicitarle su identificación porque no tenemos autoridad legítima para eso. Entonces nos hacemos acompañar de la policía, les solicitamos inicialmente de manera respetuosa al ciudadano que le enseñe, o pues, para qué estamos en el municipio y que tenemos conocimiento de que él está o vendiendo chance ilegal o lotería o en los establecimientos públicos los sorteos promocionales que son los que realizan los supermercados específicamente, aunque hay otros almacenes diferentes a supermercados que hacer sorteos promocionales. (E2)

Se reitera, entonces, que el lugar del grupo de operativos, el cual hace parte de un proceso de articulación de varias entidades, entre ellas la Policía Nacional, desarrollan los operativos, en principio, en clave de identificación, localización y verificación; y, posteriormente, en aprehensión o captura, cuando sea el 
caso. Estas labores articuladas se hacen en cumplimiento de la normatividad que hay alrededor de la ilegalidad, como se plantea a continuación.

[De] nosotros no es competencia, que nosotros nos vayamos a llevar una persona capturada, no, es la policía, nosotros acompañamos a la policía y hacemos un operativo conjunto, policía y grupo operativo. Si la policía bien lo considera, captura la persona y nosotros somos testigos de los hechos y [coadyuvamos] a esa captura, a su vez, préstamos todo el acompañamiento que requiera la policía para esto. Pero cuando la policía no captura simplemente nosotros hacemos acta de aprehensión de esos chances y nos traemos, y hacemos un protocolo de cadena de custodia y lo guardamos hasta que termine el convenio. El día que termina el convenio le entregamos todo a la Lotería de Medellín para que ellos lo guarden. (E1)

Así pues, se estableció el grupo de operativos y se priorizaron algunas zonas en las que, además de la demanda de alguna entidad municipal, se identificó que se desarrollan reiterativamente prácticas de ilegalidad, o por desconocimiento o por prácticas históricas propias del territorio. Además, teniendo en consideración las acciones de ilegalidad que han tenido mayor defraudación en los juegos de suerte y azar:

Yo creo que esto lleva mucho tiempo, ¿no? Pues, desde siglos. Pero sí, creo que yo puedo hablar de 10 o 20 años que se da ese ejercicio tan organizado en ese sentido. Sí les digo que es un asunto muy golpeado por el tema del control departamental que se viene haciendo. Cuando se erradicó de alguna manera el chance manual y llegó Gana a manejarlo, de esa manera, creo que fue un golpe importante para ese tipo de apuestas, y en adelante, creo que la tendencia ha sido a tratar de extinguirla, a que no se siga propiciando, porque entonces, por ejemplo, ocurre que hay un vendedor como de costumbre que la gente sabe que trabaja con eso y que vende muchos tipos de boletas, por ejemplo, entonces lo encuentra la policía, le quita las boletas, entonces ya no responde, entonces pasan esa clase de cosas, es un asunto de mucho tiempo. (E3)

En este apartado se constató a través de un actor comunitario cómo se desarrolla el control a la ilegalidad que se ha estructurado y organizado en el 
territorio desde años atrás. Éste deja claro las acciones propias de la Policía y la regulación que se ha impuesto, por ejemplo, con el chance manual desde la creación de la empresa Gana. Igualmente, dentro del grupo de operativos se realizan acciones de verificación de aquello que se incauta o aprehende, es decir, en articulación con la competencia y experticia de la Lotería de Medellín, se debe verificar, por ejemplo, que, en efecto, las rifas incautadas no estén autorizadas por ellos o que el material aprehendido si corresponda a una falsificación. A su vez, es importante dar cuenta de las acciones pedagógicas y de sensibilización que se desarrollan como estrategia paralela a los ejercicios de control:

Es lo mismo, acompañamiento de la policía, y hacemos todo el tema de las operativas aprehensiones, acompañamos captura. Todo igual, y a su vez solicitamos la certificación por parte de la Lotería Medellín. Eso es clave para que ellos mismos no certifiquen que esas rifas no tienen autorización. Ese es el otro procedimiento adicional o de la Alcaldía. Pero eso es adicional al procedimiento de captura para certificar todo eso, porque nosotros, simplemente, nosotros vamos, hacemos el operativo, pedimos la resolución, si la tienen la revisamos y si nos dicen que no, eso nos facultad. (E1)

Nosotros dentro del plan de capacitación tenemos todo lo que es el monopolio rentístico en el departamento de Antioquia. Yo creo que ya les hablaron sobre la ordenanza que regula todo esto aquí en el departamento y las leyes que hay para los juegos de suerte y azar. Entonces, la capacitación es básicamente en eso, en estos temas jurídicos, las consecuencias que trae para las personas que lo hacen de manera ilegal..., esa es básicamente la capacitación, la capacitación no es muy larga y está diseñada para llegarle a cualquier público. (E2)

De manera que, para concluir este apartado, desde la articulación institucional y la concreción de acciones frente a la ilegalidad a los juegos de suerte y azar se puede identificar un proceso particular: (1) la identificación y localización de los actores a partir de la denuncia ciudadana y la verificación en situ de las prácticas, (2) el operativo de incautación, aprehensión y/o captura que se da en cumplimiento de la ley y necesariamente en compañía de la Policía Nacional, (3) verificación de la ilegalidad por parte de la Lotería 
de Medellín de tal forma que la entidad competente certifique que no hay autorización de una rifa o que un material fue falsificado, (4) custodia del material incautado hasta finalización del convenio y (5) capacitaciones ciudadanas.

Acciones, fisuras y propuestas. En el ejercicio de la investigación fue recurrente hacer referencia a que la función del Estado está atravesada por un ejercicio de control en las prácticas de ilegalidad en los juegos de suerte y azar. Es decir, es desde ese lugar el Estado se mueve para regular la ilegalidad y fortalecer el ingreso de recursos provenientes de los juegos de suerte y azar - particularmente la Gobernación para invertir en salud. Sin embargo, el ejercicio de control que se establece en conjunto con la Policía Nacional ha estado acompañado de otras acciones, como se dijo atrás, que tienen como objetivo sensibilizar a los ciudadanos y al gobierno local que de alguna manera también debe acompañar esta estrategia. En este apartado se hablará de otras acciones identificadas en relación de los operativos que se puedan ejecutar, en términos locales, las dificultades que se encontraron y algunas propuestas que pueden funcionar para continuar con el desarrollo de la estrategia.

Hay unos elementos que se identificaron como dificultades -o fisuras en la estrategia-que es necesario considerar como un ejercicio evaluativo de lo que se ha desarrollado y como una forma de revisar dichas estrategias, ya que así podrían brindarse resultados más efectivos en cuanto a la recuperación de dichos recursos públicos. Por un lado, se tuvieron algunas barreras comunicativas entre las autoridades locales y el grupo de operativos, impidieron que un sector fundamental para la estrategia participara en las capacitaciones que se desarrollan. Esto podría tener como consecuencia que este sector ignorara, e incluso, pudiera justificarse para continuar con las prácticas ilegales o no autorizadas.

Porque lo único que hizo falta fue con los comerciantes porque no hubo convocatoria por parte de los secretarios de gobierno. Cuando este par de contratistas los contactaron previamente, les dijeron que esta capacitación se hiciera extensiva a comerciantes y a vendedores de chance y de loterías, que ellos identificaran ahí en el municipio. Para hacerles ver que lo que están haciendo no es legal y que lo que están 
haciendo va en contra de ellos mismos porque finalmente ese dinero está destinado sólo para salud. (E2)

En este sentido, se detecta una fisura con un posible origen en la comunicación, es decir, a quién iba dirigida. Un segundo caso identificado en el proceso, que es fundamental, es el desconocimiento de las administraciones locales sobre los juegos de suerte y azar. Ello dificulta su control y favorece las prácticas de ilegalidad en el territorio. Pero, además, a este desconocimiento podría cruzarse con un asunto de complicidad, como se deja ver a continuación:

Hay otro punto que nos ha llamado mucho la atención en estas conferencias, en estas capacitaciones, y es el desconocimiento total de las autoridades administrativas de lo que ellos tienen que hacer con respecto a estas rentas ilícitas, de las autorizaciones que ellos deben dar a las rifas cuando es una rifa a nivel municipal ellos no conocen la norma entonces es como complicado. (E2)

Sí, sé que desde diferentes instancias ya se ha dado con los entes territoriales, porque las alcaldías saben que las rifas existen, la policía sabe que las rifas existen, ahí hay un asunto que tiene que ver con la corrupción y cada municipio se va a "desregular menos". Yo creo que el departamento ha sido un poco quien ha puesto ese límite en decir no se va a continuar más con esto y como que bloquea las formas. (E3)

Estas fisuras muestran que, desde la estrategia, se podrían plantear acciones y propuestas para afianzarla, para lograr un mayor impacto y sostenibilidad en el tiempo con mayor posibilidad de réplica. Es un asunto que tiene que ver con el fortalecimiento de la relación entre lo que se centraliza en Medellín y el despliegue que se hace a otros territorios, a las administraciones locales. Aunque dichas acciones se vienen llevando a cabo, sin embargo, con lo hallado en el proceso de investigación, se referencian dos estrategias particulares: por un lado, potenciar las capacitaciones, como ejercicio con distintos actores: Administraciones municipales, comerciantes, ciudadanía en general y, por otro, fortalecer el ejercicio comunicativo desde lo local.

En términos de las capacitaciones, hay una propuesta en clave de las administraciones locales, particularmente, de los secretarios de gobierno. 
Teniendo en cuenta la dinámica que tienen los juegos, y que, como se tratará en otro apartado, hay un perfil claro de quiénes se articulan a estas redes:

Yo pensaría que desde la Gobernación podríamos hacer algo con todos los secretarios de gobierno: Una gran capacitación a ellos sobre este particular, porque la gran mayoría de rifas son locales y en esto no solamente está el señor que hace la rifa, el de la familia pudiente que pudo sacar la rifa de un apartamento, un carro, una moto, sino que también aquí entran la viejecita de la iglesia que hace las rifas, de la escuela, es un tema duro pero la idea no es llegar a atacar esa gente. (E2) ... dentro de lo que tenemos planeado, junto con la Lotería de Medellín y Gana, es hacer una capacitación en cada subregión donde vamos a convocar a los principales municipios y a todos los alcaldes de la subregión... Gana está en toda la disposición de colaborar con este programa. (E2)

Igualmente, se piensa en clave de un ejercicio comunicativo que tenga lugar en los municipios del departamento, y que pueda favorecer la capacitación y sensibilización ciudadana. Este ejercicio tiene importancia en la medida en que se puede entender el componente sociocultural que hay detrás de la práctica de los juegos de suerte y azar, como se enuncia a continuación:

Yo pienso que hacer más publicidad a esto de los juegos de suerte y azar. La gente es poco lo que sabe y, como nos hemos dado cuenta de eso, hemos propuesto hacer como unos convenios con las emisoras locales en los municipios para que pasen esa información. Para que le hagan saber a la gente que el chance manual es ilegal, que las rifas deben tener unos permisos. Ya hemos hecho contacto; igual, dentro de la labor que hacen las capacitadoras está esto: ellas ya han tenido contacto con emisoras y esta parte de la contratación para hacer las pautas publicitarias en estas emisoras locales o para que logremos que nos entrevisten para nosotros contarle a la comunidad. (E2)

De manera general, entonces, si bien se advierten unas fisuras en clave de aspectos comunicativos de conocimiento, particularmente de las administraciones locales, se presentan acciones y propuestas que buscan fortalecer estas dificultades y afianzar la estrategia desde lo local. 


\section{Sobre el pago de impuestos en los juegos de suerte y azar}

Cuando se hace referencia al pago de impuestos se habla de la obligación económica que se debe pagar a una entidad administradora determinada que, en este caso, es la Lotería de Medellín, debido a un hecho previsto en la ley. Esta categoría está relacionada específicamente con el impuesto a las modalidades que se encuentran inmersas en el monopolio rentístico de juegos de suerte y azar en el departamento de Antioquia (loterías tradicionales, juego de las apuestas permanentes o chance, rifas, sorteos promocionales y eventos hípicos). A partir de la investigación, se lograron definir los códigos que plantean los elementos generales sobre el impuesto y las posibles razones de su evasión, visto desde los participantes.

Impuesto y la evasión. El impuesto para el monopolio de juegos de suerte y azar destina un porcentaje determinado para la Administración y para el departamento, renta que tiene una especificación en la destinación y además un impacto socioeconómico dentro de las comunidades. Un participante comunitario dio a entender su conocimiento sobre la existencia de un marco legal, pero no los detalles para cada una de las modalidades; de manera general esbozó lo siguiente:

Sé que hay unas apuestas que son legales, que están en el marco de un pago de unos impuestos y, a partir de allí, hay unas garantías para el Estado, de acuerdo con el uso de estas rifas, la lotería, el chance, que son esa misma manera de hacer apuestas. (E3)

De esta manera, se podría afirmar que conocer que existen leyes que rigen algunas actividades puede significar que las características de un juego también sean reconocidas como legales; sin embargo, se puede identificar que hay actividades culturalmente adoptadas y que las comunidades no conocen la obligación tributaria en la que se puede incurrir: "o sea, una escuela va a hacer una rifa y tienen que dar el $15 \%$, que es el impuesto, y gana lo mismo según el valor de sus ventas". (E2)

Este ejemplo implica reconocer que desde las comunidades no se tiene en cuenta el impuesto que corresponde a las actividades de juegos de suerte y 
azar, ya que culturalmente éstas han sido reconocidas como prácticas en las que se incurre normalmente para recaudar fondos, para tener la posibilidad de ganar un premio, sin relacionarlo con el trasfondo del hecho generador del recaudo. Los datos aportados desde el grupo operativo de la estrategia, como resultado de las acciones desarrolladas con la población (prácticas más frecuentes que han podido ser detectadas, intervenidas o sancionadas), y los datos recogidos desde otros instrumentos de recolección de información dan pie para entender la confrontación entre las prácticas ilegales y las vivencias cotidianas de los pobladores del territorio, lo que permite explicar la participación de la población en actividades prohibidas, no legales y la evasión de impuestos. Esto se ha puesto en evidencia en la figura 2, hecha a partir de la encuesta realizada a los municipios del departamento de Antioquia para conocer aspectos inherentes a las prácticas de ilegalidad. De manera que, ante la pregunta a funcionarios y contratistas municipales sobre cuáles de los siguientes fraudes más frecuente en su municipio, el resultado fue:

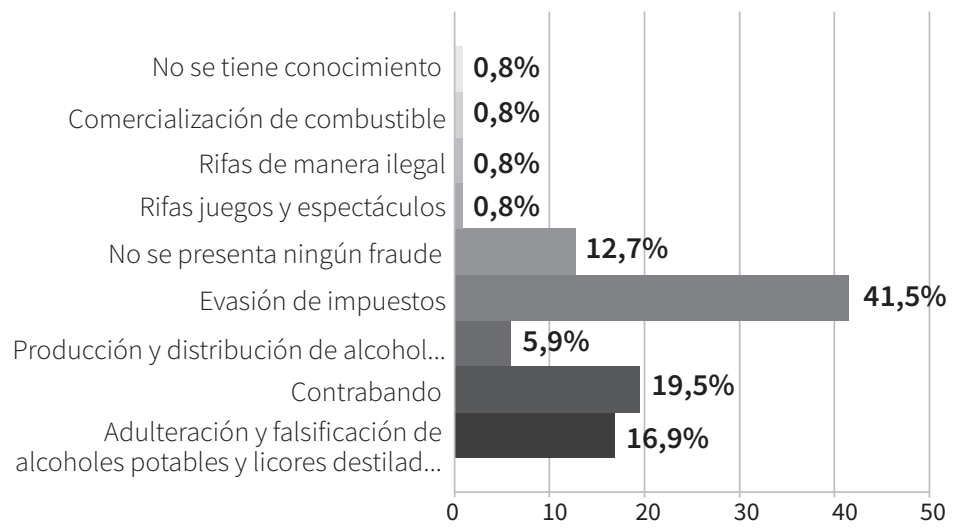

Figura 2. Frecuencia de las prácticas de ilegalidad más comunes.

Como se evidencia en la figura 2, la respuesta que más sobresale, con un $41,5 \%$, tiene que ver con la evasión de impuestos, la cual redunda en distintas prácticas de diferentes rentas, entre ellas, asuntos de juegos de suerte y azar. Igualmente, aparecen prácticas asociadas en juegos de suerte y azar directamente, con un 1,6 \%, que, si bien no parece un porcentaje significativo en comparación con los anteriores, entendiendo que la ilegalidad en este escenario repercute directamente en los recursos de la salud (como se verá más adelante), es razón suficiente para su intervención. Como se enuncia 
a continuación, la evasión del impuesto es la práctica de ilegalidad que las comunidades y demás actores reconocen como defraudación más notable, sin embargo, son percibidas de formas diferentes:

Yo, el pecado que les veo, y es lo que hemos hablado, es que no pagan unos dineros al Estado, y no hagan un proceso de formalización en ese nivel, pero no lo encuentro tan relacionado con el delito, el delito, a mi concepto, aparece cuando se nombra que es algo ilegal, y ese tema porque finalmente todos pagamos un impuesto y todos hacemos como una construcción de Estado desde allí. El delito de ellos es saltarse esa partecita, casi nada. (E3)

En este sentido, se encuentran elementos por los cuales no se da el pago del impuesto, como la no formalización de las diferentes modalidades de juego en las que se incurre, el desconocimiento de la norma y la situación social, como se deja ver a continuación:

Yo creo que esto, que al igual que muchas diferentes situaciones que están por fuera del marco de lo legal, aparecen porque el Estado en la organización que nosotros tenemos, es un Estado que hace muy complejo para ciudadanos - sobre todo de clases bajas - tener ciertas iniciativas. Yo lo comparo, por ejemplo, a cuando tú tienes una pequeña empresa, o sea, tenés que cumplir con unas normas muy rigurosas, tenés que tener unos protocolos bastantes rigurosos, tenés que cumplir con unas normatividades, tenés que tributar y, para una empresa pequeña, eso es un peso muy pesado, y hace que muchas empresas realmente no prosperen o que no puedan tener un crecimiento dentro de lo que uno puede esperar como positivo, que es lo que pasa, por ejemplo, con las grandes empresas, a mi concepción la tienen más fácil. (E3)

De esta manera, se identifica una responsabilidad que ha sido asignada al Estado, donde la normatividad y las formalidades administrativas, al parecer, significan un obstáculo para las pequeñas empresas, ya que dentro de sus alcances no les es posible cumplir de forma legal con sus actividades económicas. Esta dificultad es visible para la comunidad; un ejemplo recae sobre las personas administradoras de rifas o sorteos promocionales: 
Para esos sorteos promocionales hay que pedir autorización en la Lotería de Medellín, y también se paga impuesto sobre el valor de lo que se va a rifar: si es una moto, sobre el valor de la moto; si es una guitarra, sobre el valor de la guitarra; entonces, mira que hay otro problema que hemos visto que se presenta aquí: la Lotería de Medellín exige unas pólizas de cumplimiento. A veces, cuando la gente va a comprar la póliza porque lo que están rifando es un televisor, un horno microondas, una olla arrocera, la licuadora -que es lo que normalmente rifan en los supermercados pequeños-, las aseguradoras no quieren vender la póliza porque eso no les genera a ellos nada, y más trámites administrativos que dinero que les pueda quedar a la aseguradora, entonces no las venden, entonces fíjate que ahí hay otro problema más que se presenta y por la cual la gente decide hacerla de manera ilegal. (E2)

Así, los participantes advierten que la evasión del impuesto - que corresponde a la renta del monopolio de juegos de suerte y azar- trae consigo razones de orden estructural, sobre todo cuando se trata de rifas $y / 0$ sorteos promocionales, donde se identifican algunos vacíos normativos que obligan a que las actividades se realicen sin cumplir las formalidades documentales y económicas. Aunque exista una correspondencia legal de los grupos que operan las modalidades de los juegos, no se proponen estrategias que logren aprovechar las características contextuales de los municipios con respecto a las obligaciones pecuniarias, ocasionando así la evasión del impuesto.

\section{Prácticas de ilegalidad en los juegos de suerte y azar}

Esta categoría, dentro de los juegos de suerte y azar, abarca las prácticas ilegales que se identificaron en la investigación desarrollada y que están basadas en los lineamientos establecidos por la Ordenanza 29 de 2017. En esta categoría se abarcarán códigos sobre las modalidades más comunes (chance manual, las rifas no autorizadas, los sorteos promocionales no autorizados y la lotería falsificada); sus formas de operar y sus causas en general.

Para hablar de ilegalidad en el monopolio desde esta investigación se advierte que en los códigos de territorio y en la legitimidad de la ilegalidad hay unas especificaciones que involucran el contexto de los municipios y 
unas características históricas que marcan el desarrollo de las prácticas de ilegalidad. A partir, de la conversación se pudieron identificar otros elementos como posibles causas de fraude: el perfil de los vendedores y de los consumidores y una mirada subjetiva en lo que respecta al desarrollo de estas actividades ilegales.

Generalidades de la ilegalidad. La ilegalidad no se presenta en la misma medida en cada uno de los ejes. Uno de los entrevistados afirma que la identificación de las prácticas de ilegalidad se estudia a partir de la normatividad, estudios previos, investigación judicial, operativos. Todo ello evidencia que hay dos modalidades particulares:

Las redes están en rifas y chance. Nosotros trabajamos por todos de la misma manera, pero hay unos fraudes que se evidencian más que otros. Aquí se ve mucha rifa y estamos buscando el chance manual porque las bandas todavía la utilizan, aunque no se vea como antes. (E1)

Sin embargo, a partir de la experiencia lograda en campo y la percepción de algunos funcionarios de los municipios, se logró identificar que de esas modalidades ilegales existe una frecuencia recurrente en los sorteos promocionales y las rifas no autorizadas:

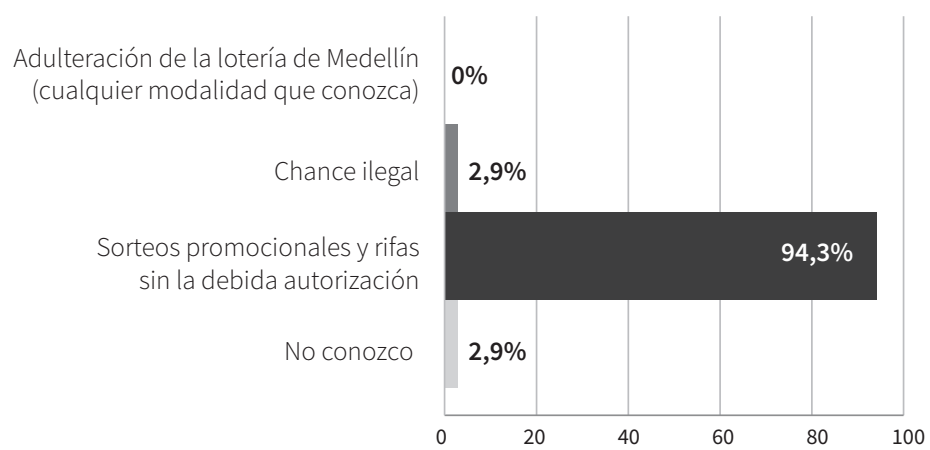

Figura 3. Fraudes más frecuentes en los municipios del departamento de Antioquia.

En la figura 3 se puede observar que la adulteración de la Lotería de Medellín es un fraude que no se ve muy a menudo en los municipios del departamento, y que, además, en una pequeña porción no se reconocen prácticas de 
ilegalidad. Sin embargo, en la investigación se hizo referencia a cada una de las modalidades de juegos y a sus prácticas particulares - ya que cada una es diferente-y a partir de allí, es importante hablar de lo que causa la ilegalidad y sus características e impactos. Es decir, no se pueden ver solo desde sus impactos, sino que es importante, para fortalecer las rentas, comprender las dinámicas en las que se mueven.

El chance manual. El chance manual, es una práctica que a lo largo de la historia ha tenido una evolución normativa y tecnológica notable en el departamento. Antes de que el chance fuera electrónico tenía una implicación en las costumbres de los antioqueños. Un entrevistado explica la forma en la que opera el chance desde la legalidad y la razón por la cual el chance manual se combate:

Porque el electrónico, que es el que expide Gana, es el único autorizado hasta el 2021, por medio de un concurso que se ganaron. Ese chance tiene unos requisitos especiales: que sea electrónico; y tiene dos formas: El que se conoce en las casetas normales de Gana, en los puntos específicos y los que son ambulantes. Todo chance manual es ilegal. (E1)

El control de este componente está entonces bajo la responsabilidad de GANA, empresa que es concesionaria del departamento y que es la única autorizada para vender chance. Esto significa que, a través de diligencias de fiscalización por parte de un tercero diferente a éste, no hay posibilidades. La ilegalidad se presenta entonces en la venta de chance manual y es donde se identifica que es una actividad rentable. Uno de los entrevistados le atribuye esta actividad a grupos organizados y criminales:

Son bandas criminales organizadas. Significa que al ser un negocio ilícito es sumamente rentable. Tenemos cifras que no son autenticadas, pero las manejamos dentro del convenio, es que da una ganancia alrededor del $80 \%$, esto significa que es algo sumamente rentable. (E1)

De este modo, se pudo identificar que esta modalidad no se origina a través del desconocimiento de la ley, pues es una actividad organizada que, según la investigación, parece estar vinculada con otras acciones de ilegalidad. Sin 
embargo, en el desarrollo de ésta no se encontró información que permitiera relacionar o afirmar que la actividad ilícita está directamente relacionada con algún grupo criminal.

¿Cómo operan las rifas no autorizadas? Históricamente, las rifas son muy conocidas y también muy activas en los municipios. Normalmente, para los participantes puede considerarse como una práctica común; se puede identificar que ilegalidad es observada por el hecho de no contar con los permisos y en las omisiones que causan evasión en los derechos de explotación; es decir, que se refieren al impuesto: "Las rifas no autorizadas están en todo el departamento de Antioquia; eso es un cáncer. La gente no paga el impuesto. Les cuento que, actualmente, eso lo pueden corroborar en Lotería”. (E1)

Aun sin autorización, las rifas operan dentro de los municipios, y dentro de ellas se identifican formas de organización formales que se pueden relacionar con el funcionamiento de una organización legal que cumple con los requisitos de fiscalización y control, dispuestas por el ente administrador facultado por la Ordenanza 29 de 2017. A continuación, se presenta la forma en la que operan las rifas ilegales y la similitud en la estructura de una empresa formal:

Hay una persona que es la dueña que se encarga de decir cuánto vale la rifa, qué se va a rifar, cuánto se va a ganar; hace el trabajo de imprimir las boletas, de entregarlas. Pero hay como otros actores que se encargan, que son como unos administradores, y esas personas reciben las rifas y las administran con los vendedores directamente. Eso pasa muchas veces porque están en diferentes municipios. Hay rifas que se venden prácticamente en todo el departamento, entonces son como diferentes personas en el contexto que se relacionan de una manera, digámoslo, como más cercana, con los vendedores; y están los vendedores, quienes directamente hacen el proceso de la venta de las rifas. Entonces, en cada escala de ese organigrama, por decirlo así, cada uno recibe una retribución económica por el trabajo que hace. (E3)

Esas rifas normalmente juegan a diario, y por eso digo que se parecen a un chance. Normalmente, se apuesta una persona, compra un número para un premio de $\$ 10.000 .000$, la pagan. (E3) 
Ellos salen a vender en los horarios donde saben que hay mayor flujo de gente en los parques, que es en horas de la tarde, y eso lo tenemos claro que en la gran mayoría de sitios específicos; normalmente lo hacen en el parque principal del pueblo y sus alrededores, las calles aledañas, todos nuestros operativos nuestros son en los parques principales. (E1)

De lo anterior, se deduce que los grupos de personas que manejan las rifas ilegales dentro de los municipios operan de manera organizada y que diferentes participantes observan que la forma de venta de estos servicios se realiza en los espacios públicos. También se identifican otras dinámicas de operar, que salidas del ámbito administrativo, pueden tener similitudes con el pago de los servicios de cada uno de los roles que se presentan en los procesos:

En el caso de los vendedores, a ellos les queda un porcentaje. Eso normalmente lo arreglan con el dueño de la rifa, con la persona que la administra, y se va como dando así. Digamos que tenemos una rifa de $\$ 2.000$, entonces, el dueño de la rifa cobra $\$ 1.200$ por cada boleta, la persona que la administra puede cobrar de ahí $\$ 100$ o $\$ 200$ por boleta, y el vendedor, por cada boleta que venda, se queda con $\$ 800$ o $\$ 900 ;$ y así funciona en todas las rifas. Obviamente, si la rifa vale un monto más alto de dinero - digamos que vendes una boleta que vale $\$ 100.000-$, te va a quedar más plata también; pero digamos que así más o menos es la estructura, y ellos acuerdan quién es el vendedor con la persona que la administra, con los límites que pone el dueño - que también tiene que pagar con la responsabilidad de responder por las rifas. (E3)

Las rifas no autorizadas tienen un trasfondo cultural que está representado en el consumidor de los servicios, las personas que cumplen determinados roles dentro de las organizaciones y la estructura de la actividad. La investigación demostró que las rifas ilegales son la modalidad de defraudación más identificada en los municipios y, además, de la cual se tiene más información sobre su operación en general.

Sorteos promocionales. La modalidad del sorteo promocional es una actividad que, comúnmente, en todas las subregiones del departamento se ve como un fin para incentivar las ventas y fidelizar los clientes de un 
establecimiento específico. Se pudo identificar que es una práctica adicional al objeto social de quien efectúa el sorteo, y que la defraudación se presenta, en gran medida, por la evasión del impuesto, el no pago de pólizas y la no formalización del hecho. La generación de beneficios se da a partir del incremento de la demanda:

Es muy sencillo: Un sorteo promocional es lo que ustedes ven comúnmente. Vamos a poner el ejemplo. Usted va a el supermercado, por ejemplo, y dice que por compras superiores a tanto usted participa por la rifa de un carro; pero debe ser al azar. Entonces, al final sacan al azar. Eso es un sorteo promocional. Eso paga impuestos. ¿Quiénes son los que más incurren? Los supermercados, los almacenes, el comercio... porque el sorteo promocional se utiliza para aumentar las ventas. (E1)

En este sentido, relacionando lo evidenciado por uno de los entrevistados con el código de impuesto, se pudo evidenciar que esta práctica se presenta por el desconocimiento de la norma, de los procedimientos normativos y/o porque el premio sujeto de sorteo tiene poco valor, comparado con el valor de los trámites. Ello genera más posibilidades de encontrar ilegalidad en pequeños y mediamos establecimientos que en aquellas grandes superficies donde los premios pueden encontrarse de mayor valor adquisitivo.

Lotería falsificada. Hablar de la modalidad de falsificación es abordar actividades que no tienen autorización, y también significa que el desarrollo de estas prácticas se basa en el enriquecimiento a través del engaño a los consumidores. El reconocimiento histórico de la Lotería de Medellín puede representar una oportunidad para el proceso ilegal, ya que los antioqueños consumen a menudo productos de esta clase. A través de los grupos operativos se logró identificar que la falsificación es una actividad común, y que se da en gran medida en zonas específicas del Área Metropolitana:

Porque se han encontrado lotería fotocopiada y falsificada en las calles de Medellín, pero eso no es muy común en los municipios; es más común en el Área Metropolitana; pero la falsifican, y qué dolor que usted compre una lotería hoy y se la gane, pero es falsa. Así que ese es nuestro trabajo. La Lotería de Medellín viene realizando unas capacitaciones para que se conozcan los elementos de seguridad y nosotros hacemos nuestro operativo. (E1) 
En este sentido, los consumidores no evidencian las habilidades ni los conocimientos necesarios para identificar las características de un billete de lotería falso o de uno legal, por lo cual, se evidencia la necesidad, por parte de las instituciones, de desarrollar actividades que estén inmersas en los procesos propios de cada territorio y que permitan fortalecer buenas prácticas de legalidad:

Ellos van a disponer de las pautas radiales de funcionarios que nos van a acompañar en las capacitaciones para que hagan directamente la capacitación en cuanto a la falsedad en la Lotería de Medellín. Nosotros ya hemos tenido dos capacitaciones con ellos, ya sabemos cómo se detecta un billete de la Lotería de Medellín falso; sabemos todos los cambios que semanalmente les hacen, porque los billetes todas las semanas son diferentes. Usted va a encontrar que el billete de esta semana no se parece al de la semana pasada. (E2)

En las incautaciones de billetes de lotería falsificados se ha podido identificar que las personas involucradas en estas actividades realizan un estudio sobre el diseño y elaboración de un billete de lotería; sin embargo, también se evidencia que algunos de estos elementos no tienen procesos elaborados:

Cualquier cosa les cambian, y hay unas letras diminutas que inicialmente tú las detectas, las ves así, y ves una raya roja; pero si tú coges una lupa, ahí va a haber un letrero, entonces hemos recibido muy buena capacitación de la lotería. (E2)

De esta manera, se evidencia que los billetes de lotería falsificados poseen unas características en similitud con la lotería autorizada, y es difícil para los consumidores reconocer elementos específicos de autenticidad, lo cual genera la defraudación en el mercado y ocasiona la necesidad de capacitar a las comunidades sobre tales prácticas.

Perfil del vendedor. Los vendedores representan un rol importante dentro de las prácticas de ilegalidad alrededor de los juegos de suerte y azar porque, por medio de ellos, se realiza la práctica final de comercialización, por lo menos en cuanto se refiere a chance manual, rifas no autorizadas y lotería falsificada. Algunos participantes advirtieron que han podido identificar desde sus 
posiciones que los vendedores tienen unos perfiles concretos y que, a partir de allí, se presume que hay una elaboración de estrategias de venta:

¿Qué hemos detectado en los municipios donde ya hemos hecho operativos? Que la gran mayoría de las personas que venden las rentas ilegales o el chance ilegal, o son personas de la tercera edad, o son personas discapacitadas. Yo pienso que en los municipios donde estas ventas ilícitas están a cargo de las bandas criminales utilizan a estas personas para ellos, y lo mismo, cuando son familias. Como lo hemos notado en determinados municipios, que los dueños de estas rifas es determinada familia del pueblo y utiliza a los discapacitados y a gente de la tercera edad para la venta de las rifas. (E2)

Pero la dificultad no es solo que lo vendan, sino el instrumento que utilizan para venderlo, que son personas ancianas, personas con discapacidades, que se aprovechan de su condición para que vendan. Ellos argumentan que son las únicas personas que le dan trabajo a estas personas. Puede ser verdad, pero para el trabajo de nosotros se nos ha dificultado porque a nosotros nos toca hacer ese control y esa vigilancia, e inmediatamente nosotros encontramos que esa gente vende chance manual tenemos que hacer algo que se llama aprehensión, lo que la policía llama incautación. (E1)

Los vendedores tienen un perfil de condiciones físicas particulares. Por lo general, se identificó que son personas de la tercera edad o personas con discapacidades mentales o físicas. A través de la investigación se evidenciaron varias posiciones respecto a las causas de la ejecución de dichas actividades, entre ellas, la estrategia comercial por parte de los grupos que operan dichas modalidades y que relacionan el éxito de la venta con la lástima de los compradores.

En los apartados anteriores, se pudo identificar que se supone una relación directa entre el estado de la persona y las intenciones organizacionales determinadas; pero también, desde otra perspectiva, se relaciona la participación de estas personas con oportunidades laborales que requieren un perfil que involucra un grado de responsabilidad, confianza y habilidades de venta: 
En las organizaciones que yo he conocido es como una cosa selecta, porque se le entrega o se le intenta entregar rifas a personas que se sabe van a responder por ellas. Que no ocurra, pues, por ejemplo, que una persona se llevó boletas para vender quince días y no apareció, y se quedó con toda la plata, y al fin también se embaló a la hora de pagar el premio. Entonces, no a cualquier persona se le entrega esa tarea de trabajar en las rifas; también conozco el caso de un señor que tiene una discapacidad. El señor está en silla de ruedas, no puede caminar; entonces el señor sale en la silla de ruedas, se hace en unas esquinas y vende diferentes rifas porque no tiene como oportunidad de desempeñarse laboral en otro lugar. Es muy teso, me parece muy complejo. (E3)

En este sentido, la participación de personas con esas características reconocidas admite que existe una brecha en las oportunidades ofrecidas dentro del mercado laboral y que el reconocimiento de las facultades es un tema estructural que obstaculiza el sustento financiero de algunos grupos familiares. Es así, entonces, que se hace énfasis en las posibles causas que los vendedores tienen para participar en estas actividades económicas y que se reconocen a continuación:

Muchas personas se ven beneficiadas de eso. Yo me atrevo a decir que muchas personas lo necesitan, muchas personas tienen su sustento desde allí; que muchas personas que no tienen un sustento económico, laboral, en muchos sentidos, realmente este tipo de procesos son los que les da un dinerito para subsistir. Hay personas que viven del diario, y el diario se lo hacen con esas boletas. (E3)

Hay unas condiciones socioeconómicas que también hacen un empuje allí. De alguna manera, vos tenés que conseguir con qué vivir; de alguna manera vos tenés que conseguir con qué mantenerte. Creo que no es lo mismo, y no quiero señalar que el Estado tendría que ser completamente asistencial, pero yo sí creo que con las condiciones de inequidad es perfectamente normal que las personas se adhieran a este tipo de actividades; tanto quien las vende porque necesita subsistir, como quien las compra, que tiene la esperanza de que le va a llegar una platica y la va a invertir en alguna cosa que necesite. Y que creo que el Estado, al 
menos, con respecto - bueno, y pasa- a toda esa organización general que veo ahí que alimenta todas esas otras situaciones. (E3)

El perfil de los vendedores, entonces, se intenta explicar a través de los entrevistados desde varios elementos: La influencia social, la condición física y/o mental, las condiciones socioeconómicas, las oportunidades laborales y las habilidades para la venta. Sin embargo, además de la identificación de esos elementos, también se pudo evidenciar que hay un problema de salud pública alrededor de los vendedores, que también es vista en los consumidores y que es causal para la actividad del vendedor:

Hay otras personas que, yo creo, sí se ve un problema social teso, porque están las personas que están como en la mendicidad, que dicen: vea cómpreme esta boleta que me pasa tal cosa, o ayúdeme con esto que necesito para tal cosa. Pasan esas situaciones. También he conocido personas que se dedican a vender rifas, pero con asuntos muy tesos: personas que tienen adicción a los juegos de azar. Entonces a veces se ve que van y venden y se van a jugar en los casinos con lo que hacen. (E3)

Causas del consumidor y legitimidad. A través de la investigación se pudo identificar un código relacionado con las prácticas de ilegalidad: Se trata de que las personas acceden a participar dentro de las modalidades de defraudación ya expuestas. Los consumidores se han identificado en varios rangos de edad y en varios rangos socioeconómicos; por ejemplo, las personas de la tercera edad representan el mayor consumo de estas prácticas dentro de los pueblos. Las razones pueden variar: El desconocimiento de la norma, de las tecnologías y/o de las tradiciones arraigadas:

Bueno, yo pienso que hay que dedicar más recursos a las comunicaciones en estos convenios, porque de la única forma que uno entera a una comunidad es a través de los medios de comunicación, y en los pueblos, a través de la radio. Todo el mundo escucha radio. No tanto a través de las redes sociales, porque, fíjate que hace un momentico hablábamos que la gente que más compra chance manual son la gente de la tercera edad; entonces, ellos no tienen acceso al internet. Algunos municipios no hay internet o llega muy deficiente, entonces, fíjate que si deben 
destinar más recursos es a eso, a las comunicaciones a través de propagandas en la televisión, en el canal regional en Teleantioquia; que todo el mundo lo ve en este departamento, todo el mundo ve noticias de Teleantioquia. (E2)

En este sentido, el desconocimiento de la legalidad y el poco acceso a las tecnologías representan una de las causales para que el consumidor acceda a estas modalidades ilegales, y desde los participantes se hace énfasis constante en que las comunidades necesitan ser capacitadas en temas relacionados para poder fortalecer una cultura de legalidad en el departamento. En pocas palabras, este entrevistado se refiere al problema de salud pública como una causal del consumidor:

Porque a las personas les gusta apostar por una necesidad económica o porque les gusta el riesgo. A las personas les gusta eso. Pienso yo que no es un asunto tan dañino para la gente, porque no hablaos del aislamiento que suscita a una adicción, de los problemas de salud y demás, que puede generar una adicción a sustancias. (E3)

De esta manera, se podría afirmar que la investigación no logró determinar una relación profunda del riesgo a la salud generado por las adicciones al juego, con las causales de la demanda de los juegos ilegales, pero a través de uno de los entrevistados sí se logró establecer que la legitimidad de las modalidades dentro de los municipios ha permitido que las actividades permanezcan funcionando:

Cuando son rifas muy grandes - hay rifas donde puedes ganarte $\$ 100.000 .000$ y la boleta vale $\$ 100.000-$, eso también puede depender; nadie le va a comprar una boleta de esa índole sin tener una garantía de que es una persona confiable que les va a pagar el premio cuando se la ganen. En caso tal, si se da que, por alguna razón, alguien se ganó una rifa y no se la pagan, eso se esparce, y de una la gente empieza a conocer que no es un asunto confiable y no se sigue comercializando, o se bajan las ventas, cualquier cosa. Se maneja mucho de esa manera. (E3)

Se logró evidenciar también que la confianza es una causal para que el consumidor acceda a tales actividades. En los municipios, las comunidades 
reconocen a las organizaciones que operan las modalidades de juegos $y$, además, defienden sus actividades económicas, tal como se expresa a continuación:

¿Hay resistencia de la gente? Claro que la hay. No se presenta directamente de la persona que está realizando la actividad, sino de la gente que la rodea, de la gente que normalmente está en la plaza del pueblo o en el parque principal, que es donde están los venteros de las rifas o de los chances. Ellos son los que, normalmente, por decirlo de alguna forma, atacan al contratista nuestro o reaccionan ante la policía que les vaya a quitar sus boletas o chance, o judicializarlos porque dependiendo del caso la policía es quien decide si hace la detención del ciudadano o sencillamente aprehendemos el material. (E2)

La investigación, además de identificar que los consumidores y la comunidad defienden las actividades económicas no autorizadas, debido a la confianza que tienen para los grupos organizados y las relaciones sociales que se presentan en la mayoría de los municipios del departamento de Antioquia, evidenció que existe conocimiento respecto de las consecuencias a las que se enfrentan las personas relacionadas en la ejecución de estas acciones legales $y$, por lo tanto, es que en el momento en que se realiza un acto de aprehensión o judicialización la comunidad se opone.

Pasa que al vendedor lo vean en la calle, lo capturen, le quiten todo, lo lleven al comando. Puede que lo judicialicen, puede que vuelvan y lo suelten, porque el argumento que ellos dicen es: no las voy a dejar de vender porque, entonces, qué voy a comer. También ha pasado que se criminaliza y se persiga al dueño de la rifa. Se han hecho allanamientos, capturas, se han hecho expropiaciones. Yo creo que es en todos los niveles que se está dando este asunto de persecución tan agresiva. Ahora, creo que habrá quienes se perjudican en una menor o en una mayor medida, dependiendo de su situación y demás. Yo creo que, en el caso de los dueños de rifas, como les digo, es una cosa muy arriesgada, porque pueden perderlo todo lo que tengan: ir presos porque los pueden meter a la cárcel por esto. Un vendedor se puede ver altamente perjudicado por esto. (E3) 


\section{Posturas comunitarias y su relación con la salud}

Desarticular los resultados de la dimensión comunitaria en los juegos de suerte y azar y su relación con la salud complejizaría el análisis del fenómeno, teniendo en cuenta que las prácticas de los juegos de azar están enraizadas en un marco sociocultural que implica no solo su desarrollo sino también su persistencia en el tiempo. Es importante entonces, analizar algunos aspectos comunitarios que permitan entender el fenómeno.

Percepción comunitaria. Un elemento importante para la comprensión de la ilegalidad tiene que ver con la forma cómo estas prácticas se han imbricado en la sociedad, es decir, cómo los distintos actores sociales se vinculan al engranaje de la ilegalidad en los juegos de suerte y azar y cuál es la percepción del mismo. De manera general, se podría decir que se desconoce, en algunos casos, que puede haber ilegalidad en los juegos de suerte y azar, bajo determinadas condiciones $y$, en otras ocasiones, si bien hay un conocimiento de su ilegalidad, su práctica es resultado de una tradición comunitaria o por necesidad laboral. Lo cierto del caso es que la ilegalidad, en los juegos de suerte y azar requiere de la comprensión de los actores sociales que están inmersos en esta lógica.

Un aspecto importante que se encontró tiene que ver con las relaciones que se tejen para establecer confianzas en la comunidad, y que hace que se pueda sostener el negocio en los distintos territorios: se establecen relaciones y vínculos que implican que el negocio se sostenga y que no parte de la coerción, sino de prácticas que se convierten en tradiciones entre los distintos actores sociales:

Sobre todo, éstas que son pequeñas, la gente las conoce. De hecho, hay personas que simplemente les preguntan a las personas que venden: ¿Qué rifa tiene?, y la compran. Desde mi experiencia, como que se crea una reputación al respecto, en el lenguaje común. Desde las conversaciones entre las personas se reconoce quiénes hacen estos procesos de una manera como confiable; que en caso tal van a pagar, y quienes no son tan serios con el asunto y no ofrecen garantías. Eso no sé cómo explicarlo. Es como una cosa fuera de lo común, ¿cierto? Como si hubiera ahí un voto de confianza, pero que es como con respecto a 
la experiencia que van teniendo las personas; y ahí se va yendo, como una recomendación; y se hace a nombre del dueño, o de la persona que hace el proceso de administración. (E3)

Estas relaciones de confianza que se construyen en los distintos territorios se pueden entender como acciones de legitimación de las prácticas legales o ilegales de los juegos de suerte y azar, en el sentido de que son prácticas que se hacen cotidianas y que parten de la decisión del consumidor de apostar o no en este tipo juegos. Es decir, en esta práctica, la confianza que se tiene en quien realiza las rifas es fundamental; por ejemplo, una persona (vendedor) que incumpla con el pago de los premios, pierde legitimidad en su comunidad:

... sí, se da que, por alguna razón, alguien se ganó una rifa y no se la pagan. Eso se esparce y de una; la gente empieza a conocer que no es un asunto confiable, y no se sigue comercializando, o se bajan las ventas, cualquier cosa. Se maneja mucho de esa manera; lo mismo pasa cuando son rifas muy grandes; hay rifas donde puedes ganarte $\$ 100.000 .000$ y la boleta vale $\$ 100.000$, eso también puede depender, nadie le va a comprar una boleta de esa índole sin tener una garantía de que es una persona confiable que les va a pagar el premio cuando se la ganen, en caso tal. Eso respecto a esa organización, y hay personas que tienen muchas rifas, que tienen rifas pequeñas, rifas grandes, y ese tipo de cosas. (E3)

Se podría afirmar así que el fundamento para que los juegos de suerte y azar ilegales tengan un lugar importante en las prácticas de la comunidad son las relaciones de confianza que se van legitimando y replicando en el nicho social donde operan.

Actores involucrados: causas e impactos. En clave de lo que se ha planteado en cuanto a la legitimidad que se otorga en las comunidades a quienes hacen parte de los juegos de suerte y azar ilegales para poder adquirir el producto, se dejan ver también unas particularidades frente a quienes hacen parte de la estructura de dichos juegos que, en algunos casos, pueden ser personas que por sus condiciones de vulnerabilidad económica o social acceden a pertenecer al proceso; por ejemplo, en rifas ilegales o el chance manual. Esta 
situación cobra relevancia en la medida en que las rifas ilegales se pueden entender como una opción laboral entre distintas personas, de la forma que se explica a continuación:

Porque, finalmente, muchas personas se ven beneficiadas de eso. Yo me atrevo a decir que muchas personas lo necesitan, muchas personas tienen su sustento desde allí; que muchas personas que no tienen un sustento económico, laboral, en muchos sentidos, realmente este tipo de procesos son los que les da un dinerito para subsistir. Hay personas que viven del diario y el diario se lo hacen con esas boletas, entonces; antes de que empezara todo este tema de esa persecución. (E3)

Otro relato que permite verificar el perfil de las personas que tienen vínculos con el tema de las rifas o chance ilegal, en el que se da cuenta del uso de personas discapacitadas y/o con dificultades económicas, explica el fenómeno así:

Hay personas que tienen mucha necesidad económica, y con las rifas se sostienen. Hablo de personas que no tienen como un acceso real a oportunidades laborales, y desde allí se dedican a la venta de boletas. En las organizaciones que yo he conocido, es como una cosa selecta, porque se le entrega o se le intenta entregar rifas a personas que se sabe van a responder por ellas. Que no ocurra pues, por ejemplo, que una persona se llevó boletas para vender... quince días y no apareció, y se quedó con toda la plata y, al fin, también se embaló a la hora de pagar el premio. Entonces, no a cualquier persona se le entrega esa tarea de trabajar en las rifas. También conozco el caso de un señor que tiene una discapacidad: el señor está en silla de ruedas, no puede caminar. Entonces el señor sale en la silla de ruedas, se hace en unas esquinas y vende diferentes rifas, porque no tiene como oportunidad de desempeñarse laboral en otro lugar, es muy teso, me parece muy complejo. (E3)

En este escenario también se identificó otro perfil que tiene que ver directamente con la salud, y podría hacer referencia a los impactos psicosociales que pueden traer los juegos de suerte y azar en los distintos 
actores sociales. Es decir, se puede presentar como un escenario en que se dejan ver varios asuntos: Por un lado, como una forma en la que algunas personas que se encuentran en situaciones de extrema pobreza o que habitan la calle, pueden obtener dinero:

Hay otras personas que yo creo si se ve un problema social teso; porque están las personas que están como en la mendicidad, que dicen, vea cómpreme esta boleta que me pasa tal cosa, o ayúdeme con esto que necesito para tal cosa; pasan esas situaciones. (E3)

Y, por otro lado, como un problema directo a la salud mental, en términos de prácticas de abuso y adicción con los juegos de suerte y azar:

También he conocido personas que se dedican a vender rifas, pero con asuntos muy tesos; personas que tienen adicción a los juegos de azar. Entonces, a veces, se ve que van y venden y se van a jugar en los casinos con lo que hacen para vender. (E3)

Así pues, alrededor de los impactos que puede generar la existencia de juegos de suerte y azar ilegales, se articulan dificultades en salud pública y mental con otras dificultades que se pueden presentar en clave de lo económico y de vulnerabilidad. De otro lado, y que se articula a los actores que hacen parte de este proceso, hay una ambivalencia entre la percepción que tiene la comunidad de la relación de los juegos ilegales y actores armados, la cual no reconoce una relación directa con los mismos, quizá porque se ha asociado los juegos de suerte y azar con acciones propias de comerciantes, familias o personas particulares:

No. Miren, yo lo que he conocido - que no puedo generalizarlo-, lo que he conocido ha sido sobre todo con otras actividades económicas, como tener ganado; pero como ese tipo de cosas, por ejemplo, cosas de hipotecas, de vender y comprar cosas así. Conocí una vez a alguien que tenía su rifa y tenía su mina, y la mina la tenía con sus procedimientos, entre lo terrible que es la minería, pero con lo que se pide en el contexto, digamos que legal. ¿Que yo realmente haya sabido que haya alguien, que haya conocido una persona, por ejemplo, que venda rifas y venda drogas, o que se sepa que algún vendedor no le pagó la plata de una 
rifa, entonces lo mandó a que le lastimaran o lo asesinaran? No, yo realmente nunca he conocido eso. (E3)

Si bien, no necesariamente se reconoce que puede haber una cercanía entre esos procesos, como se vio en el rastreo al archivo noticioso, si hay bandas que operan, particularmente en relación a los juegos de suerte y azar, lo cual implica una estructura organizada en los distintos territorios.

Entre la institucionalidad y la comunidad. Un elemento clave que aparece en la comunidad es la posibilidad de la interlocución con la institucionalidad, en clave de favorecer la comprensión de la ilegalidad en los juegos de suerte y azar en sus territorios. En algunos casos, la comunidad percibe que el ejercicio que hay de fondo en los juegos de suerte y azar quizá no tenga implicaciones tan serias como otras prácticas de ilegalidad o que hay un imaginario en el que la razón de su legitimidad se da en el marco de que éstas están resolviendo necesidades fundamentales de las personas que han tenido pocas oportunidades. No fue tarea de esta investigación valorar o enjuiciarlas, pero sí poner en evidencia las consideraciones que dan cuenta de uno de los porqués de la ilegalidad en los municipios antioqueños.

Así pues, la vulnerabilidad social y el acceso a oportunidades se convierten en una justificación para hacer parte de la ilegalidad, pero también es una demanda que se le hace al Estado para evitar que los actores sociales se vinculen a estas dinámicas:

Hay un sujeto que responde por lo que hace, también hay unas condiciones socioeconómicas que también hacen un empuje allí. De alguna manera vos tenés que conseguir con qué vivir, de alguna manera vos tenés que conseguir con qué mantenerte; creo que no es lo mismo, y no quiero señalar que el Estado tendría que ser completamente asistencial; pero yo sí creo que con las condiciones de inequidad es perfectamente normal que las personas se adhieran a este tipo de actividades, tanto quien las vende porque necesita subsistir, como quien las compra que tiene la esperanza de que le va a llegar una platica, y la va a invertir en alguna cosa que necesite. Y que creo que el Estado, al menos, con respecto, bueno, pasa como toda esa organización general que veo ahí que alimenta todas esas otras situaciones. (E3) 
Respecto a esto, se dejan ver dos asuntos: por un lado, las propuestas propias de las instituciones encargadas del fortalecimiento de la legalidad en relación a los juegos de suerte y azar y, por otro, la perspectiva de la comunidad en la que se pueda articular con el Estado:

No he conocido de manera amplia un procedimiento que implique sentarse como, por ejemplo, eso que ustedes están haciendo en este momento, sentarse, escuchar, qué pasa con eso, cuáles son los asuntos que se mueven de forma interna con esa situación. Y creo que se tiende a asociar a las apuestas ilegales con otras actividades ilegales. Normalmente, como que se piensa que en ese marco de ilegalidad como que todo se vale. Es algo muy personal, porque es mi experiencia. Yo he mirado que son personas con valores éticos muy definidos, como con una seriedad con respecto a lo que hacen. Es que es su trabajo formalmente, y lo hacen bien. (E3)

Por su parte, desde las instituciones se han llevado a cabo procesos que permiten incidir en la comunidad: actores sociales particulares y seleccionados como actores clave en la comunidad y que permiten replicar las prácticas de legalidad. En este caso se han llevado a cabo acciones puntuales, como capacitaciones o acercamiento tecnológico a quienes subsisten en el marco de la ilegalidad en los juegos de suerte y azar:

Hicieron todos los municipios. Hicieron capacitaciones en los comandos de estación de policía; hicieron contacto con las secretarías de gobierno de cada municipio, fueron muy bien recibidas. La gran mayoría de los funcionarios del gobierno local les manifestaron que estaban muy satisfechos de ver que llegaba gente del gobierno central, a verlos, a llevarles cosas buenas, que eso hacía falta en sus municipios. (E2) Exactamente, los requisitos para hacer la entrega de un datafono de estos a una persona, no. Pero no son cosas a las cuales no pueda acceder cualquier persona. Es fácil acceder a ello, y eso muchas veces la gente no lo entiende, o les da miedo la utilización de esas máquinas, porque son analfabetas o tienen algún defecto físico que les impida operarla, porque no están en la cultura. (E2) 
En esta lógica, entonces, se pueden presentar propuestas y recomendaciones que permitan avizorar un panorama distinto en lo que sucede con la ilegalidad en los juegos de suerte y azar y, quizá, construir estrategias que ayuden a fortalecer los recursos del departamento y, particularmente de la salud. Pero, a su vez, que permita comprender el lugar de los actores sociales que se relacionan con las mismas, desde el marco sociocultural en el que se hallan:

Yo no sé, es que yo siento que habría que tener, primeramente, que reconocer que es lo que se mueve acá y permitir unos mecanismos; bueno... cómo organizar los pagos de manera que siga siendo un negocio rentable para el Estado; pero también para los que lo trabajan, ¿cómo adelantar ese tipo de estrategias? Yo pienso que no puedo dar una respuesta puntual, pero sí creo que escuchando las realidades y contextos; porque, imagínense ustedes que las personas que trabajan en estas rifas, por ejemplo, ponerlas en una estructura como la que tiene Gana: vaya siéntese en una oficina, venda tales cosas, o manéjelo así... posiblemente no vaya a funcionar; habría que adoptar unas medidas que les permita entrar en un marco de legalidad sin tener que modificar la forma en la que funcionan, porque tienen una función muy específica con respecto a sus actores; y la manera en la que se mueven, no sé, tendrían que sentarse a hablar con los dueños y con los que están directamente en la venta y en el trabajo para adoptar. Yo pienso que sí se podría. Lo que pasa es que no se le puede imponer una norma a otro sin escucharle cuál es la manera en la que se mueva y opera. (E3)

\section{Resultados de la medición de la defraudación}

A continuación, se presentan los resultados sobre la defraudación al departamento de Antioquia en cuanto a la renta del monopolio de juegos de suerte y azar, a partir de la información obtenida durante el periodo comprendido entre enero y septiembre del año 2019 y con la cual se construyó el presente informe.

Según el trabajo de campo realizado por el grupo de operativos de la Lotería de Medellín en los municipios del departamento, la información recolectada se clasificó así: Tipo de aprehensiones, unidades básicas aprehendidas, precios 
unitarios y precios totales. En la tabla 1, se presentan las cantidades, valores y porcentajes representativos de aprehensiones relacionadas con actividades con los juegos de suerte y azar:

Tabla 1. Cantidades, valores y porcentajes representativos de aprehensiones relacionadas con los juegos de azar.

\begin{tabular}{|l|c|c|c|c|c|c|}
\hline Aprehesión & $\begin{array}{c}\text { Even- } \\
\text { tos }\end{array}$ & \% Evt. & $\begin{array}{c}\mathbf{N}^{\circ} \\
\text { Unidades }\end{array}$ & \% Und. & $\begin{array}{c}\text { Precio } \\
\mathbf{\$} / \mathbf{U} .\end{array}$ & Pre. Total \\
\hline Chance ilegal & 21 & $4,8 \%$ & 1.756 .139 & $85,7 \%$ & $5.142,22$ & 9.030 .453 .089 \\
\hline Rifas ilegales & 372 & $85,7 \%$ & 231.213 & $11,3 \%$ & $28.302,12$ & 6.543 .818 .072 \\
\hline $\begin{array}{l}\text { Sorteo } \\
\text { promocional }\end{array}$ & 41 & $9,4 \%$ & 60.671 & $3,0 \%$ & $1.206,01$ & 73.169 .833 \\
\hline Total & $\mathbf{4 3 4}$ & $\mathbf{1 0 0 , 0} \%$ & $\mathbf{2 . 0 4 8 . 0 2 3}$ & $\mathbf{1 0 0 , 0} \%$ & $\mathbf{7 . 6 4 0 , 2 6}$ & $\mathbf{1 5 . 6 4 7 . 4 2 8 . 2 1 0}$ \\
\hline
\end{tabular}

Elaboración propia.

En la tabla 1 se evidencia que la cantidad de aprehensiones realizadas en chance ilegal es significativamente superior a las que se realizaron sobre rifas y sorteos promocionales, pese a que los eventos sobre chance fueron menores respecto a otros elementos. Por lo general, los elementos aprehendidos son talonarios de chance manual y el precio promedio por unidad se estima en $\$ 5.142$, en tanto que el precio promedio de las rifas se calcula en $\$ 28.302$; es decir más de cinco veces el precio de cada chance.

Los porcentajes reflejan con claridad la forma cómo se distribuye la incidencia económica de las aprehensiones relacionadas con los juegos de suerte y azar durante el período considerado: Casi el $86 \%$ en chances, $11 \%$ en rifas y cerca del $3 \%$ en sorteos promocionales. Es decir, durante este periodo los grupos de operativos hallaron más elementos de ilegalidad en la modalidad del chance manual dentro del territorio antioqueño que en otras modalidades.

El valor total estimado sobre las aprehensiones durante los nueve meses recorridos del año, asciende a un poco más de $\$ 15.647$ millones de pesos. Cantidad significativa, no solo en comparación con el presupuesto global del departamento, sino como el valor que en sí mismo representa el dinero 
que deja de percibir el departamento para inversión social. De continuar las cifras obtenidas en aprehensiones durante estos nueve meses de 2019, podría pensarse que al final del año podría contarse con una cifra cercana a los $\$ 21.000 .000 .000$ en defraudación.

A partir de este estudio también se pudo establecer que la información presentada por modalidad de juego de suerte y azar, se podría abordar desde la especificación de la ubicación geográfica, porque esto permite evidenciar en cuáles territorios se presentan más prácticas de ilegalidad, desde una mirada de control estatal, y luego se puede contrastar con las perspectivas de los participantes de las entrevistas. La distribución en los 434 eventos de aprehensión realizados sobre las modalidades de los juegos de suerte y azar, realizados en los diferentes municipios del departamento de Antioquia, se presentan en la tabla 2:

Tabla 2. Distribución de la cantidad de aprehensiones en Antioquia. Eventos según lugar geográfico

\begin{tabular}{|l|c|c|c|c|c|}
\hline \multicolumn{1}{|c|}{ Lugar eventos } & Chances & Rifas & Sorteos & Total & $\%$ Lugar \\
\hline $\begin{array}{l}\text { Resto del } \\
\text { departamento }\end{array}$ & 21 & 369 & 25 & 415 & $95,6 \%$ \\
\hline Área Metropolitana & & 3 & 16 & 19 & $4,4 \%$ \\
\hline Total & $\mathbf{2 1}$ & $\mathbf{3 7 2}$ & $\mathbf{4 1}$ & $\mathbf{4 3 4}$ & $\mathbf{1 0 0 , 0} \%$ \\
\hline \% juegos & $\mathbf{4 , 8} \%$ & $\mathbf{8 5 , 7} \%$ & $\mathbf{9 , 4} \%$ & $\mathbf{1 0 0 , 0} \%$ & \\
\hline
\end{tabular}

Elaboración propia.

La cantidad de eventos de aprehensión en el área metropolitana es significativamente inferior a los que se realizan en el resto del departamento de Antioquia. También se observa que la mayor cantidad de eventos de aprehensión corresponde a las rifas ilegales, con un 85,7 \%. Se puede decir que las rifas ilegales es la práctica más representativa en el departamento de Antioquia, en comparación con los sorteos promocionales no autorizados, el chance manual y la lotería falsificada. Aunque en términos económicos el informe demuestra que el chance manual es la práctica con estimaciones más altas, las rifas ilegales son la práctica más reconocida dentro de los municipios, como lo evidencian las categorías anteriormente desarrolladas. 
El valor de defraudación según el lugar geográfico también es importante tenerlo en cuenta, porque demuestra que las prácticas ejercidas históricamente en el departamento siguen teniendo auge en los municipios de las subregiones más no en el área metropolitana. A continuación, se presenta la tabla 3 , que evidencia tal información:

Tabla 3. Valor defraudación según lugar geográfico.

\begin{tabular}{|l|c|c|c|c|}
\hline \multicolumn{1}{|c|}{ Procedencia } & Unidades & P/U & V. Total & $\%$ \\
\hline $\begin{array}{l}\text { Resto del } \\
\text { departamento }\end{array}$ & 2.016 .631 & $7.747,0$ & 15.622 .928 .000 & $99,8 \%$ \\
\hline $\begin{array}{l}\text { Área } \\
\text { Metropolitana }\end{array}$ & 31.392 & 780,6 & 24.505 .000 & $0,2 \%$ \\
\hline Total & $\mathbf{2 . 0 4 8 . 0 2 3}$ & $\mathbf{7 . 6 4 0 , 3}$ & $\mathbf{1 5 . 6 4 7 . 4 3 3 . 0 0 0}$ & $\mathbf{1 0 0 , 0} \%$ \\
\hline
\end{tabular}

Elaboración propia.

La cantidad de unidades aprehendidas en el área metropolitana fue de 31.392 , mientras que en el resto del departamento ascendió a 2.016.631, que se representa un $0,2 \%$ de las aprehensiones realizadas en el periodo 2019. A continuación, en la tabla 4 se presenta la distribución de las aprehensiones según mes y tipo de modalidad.

Tabla 4. Eventos según mes y tipo.

\begin{tabular}{|l|c|c|c|c|c|}
\hline \multicolumn{1}{|c|}{ Meses } & Chances & Rifas & Sorteos & Total & \%/Mes \\
\hline Enero & 8 & 39 & 5 & 52 & $\mathbf{1 2 , 0} \%$ \\
\hline Febrero & 4 & 53 & 11 & 68 & $\mathbf{1 5 , 7} \%$ \\
\hline Marzo & & 46 & 11 & 57 & $\mathbf{1 3 , 1} \%$ \\
\hline Abril & 2 & 26 & 4 & 32 & $\mathbf{7 , 4} \%$ \\
\hline Mayo & 2 & 65 & 1 & 68 & $\mathbf{1 5 , 7} \%$ \\
\hline Junio & 1 & 21 & 1 & 23 & $\mathbf{5 , 3} \%$ \\
\hline Julio & & 12 & 3 & 15 & $\mathbf{3 , 5} \%$ \\
\hline Agosto & 3 & 35 & 3 & 41 & $\mathbf{9 , 4} \%$ \\
\hline Septiembre & 1 & 75 & 2 & 78 & $\mathbf{1 8 , 0} \%$ \\
\hline
\end{tabular}




\begin{tabular}{|l|c|c|c|c|c|}
\hline \multicolumn{1}{|c|}{ Meses } & Chances & Rifas & Sorteos & Total & $\% /$ Mes \\
\hline Total & $\mathbf{2 1}$ & $\mathbf{3 7 2}$ & $\mathbf{4 1}$ & $\mathbf{4 3 4}$ & $\mathbf{1 0 0 , 0} \%$ \\
\hline \%/juego & $\mathbf{4 , 8} \%$ & $\mathbf{8 5 , 7} \%$ & $\mathbf{9 , 4} \%$ & $100,0 \%$ & \\
\hline
\end{tabular}

Elaboración propia.

Los meses en los cuales se realizaron más aprehensiones por parte de los grupos operativos fueron: Septiembre, con 78 eventos (18\%), febrero y mayo, con 68, (cada uno el 15,7 \%). También se identificó que el tipo de aprehensión más significativa durante los operativos fueron las rifas ilegales, que representaron el 85,7\%. Ahora bien, se identificó, además de la cantidad de eventos de aprehensiones por mes, el valor de defraudación, todo ello consignado en la Tabla 5.

Tabla 5. Distribución de la cantidad de eventos por mes y valor de defraudación: eventos y costos.

\begin{tabular}{|l|c|c|c|c|}
\hline \multicolumn{1}{|c|}{ Mes } & Eventos & N. $^{\circ}$ Unidades & V. Total & Promedio \\
\hline Enero & 52 & 14.017 & 784.270 .000 & $55.951,34$ \\
\hline Febrero & 68 & 14.915 & 1.071 .825 .000 & $71.862,22$ \\
\hline Marzo & 57 & 48.537 & 1.559 .202 .000 & $32.123,99$ \\
\hline Abril & 32 & 1.727 .178 & 8.548 .629 .000 & $4.949,48$ \\
\hline Mayo & 68 & 99.069 & 784.372 .000 & $7.917,43$ \\
\hline Junio & 23 & 60.855 & 302.497 .000 & $4.970,78$ \\
\hline Julio & 15 & 29.483 & 45.430 .000 & $1.540,89$ \\
\hline Agosto & 41 & 14.283 & 874.463 .000 & $61.224,04$ \\
\hline Septiembre & 78 & 39.686 & 1.676 .745 .000 & $42.250,11$ \\
\hline Total & $\mathbf{4 3 4}$ & $\mathbf{2 . 0 4 8 . 0 2 3}$ & $\mathbf{1 5 . 6 4 7 . 4 3 3 . 0 0 0}$ & $\mathbf{7 . 6 4 0 , 2 6}$ \\
\hline
\end{tabular}

Elaboración propia.

En la Tabla 5 se aprecia que durante el mes de abril se presentó la mayor defraudación, con un valor altamente significativo en comparación con los otros meses. Alrededor de $\$ 8.548$ millones de pesos estimados; seguido de los meses de septiembre, con $\$ 1.676$ millones de pesos; marzo, con $\$ 1.559$ millones, y 
febrero con cerca de $\$ 1.072$ millones de pesos. Vale anotar que, en este mismo mes se presentó la mayor cantidad de unidades incautadas, pero no es el mes en el que se haya llevado a cabo la mayor cantidad de eventos de aprehensión.

A partir de los resultados de las intervenciones realizadas durante el periodo enero-septiembre de 2019 se puede afirmar que las aprehensiones realizadas en los municipios por fuera del Área Metropolitana fueron mayores y el valor de la defraudación fue significativamente más alto en esos mismos municipios. Además, la mayor modalidad de los juegos de suerte y azar con prácticas de ilegalidad son las rifas ilegales, que representan cerca del $86 \%$ de las aprehensiones realizadas. Aunque los datos demuestren que se aprehenden más unidades de chance ilegal que de rifas ilegales, la incidencia económica del chance ilegal está cerca al $86 \%$, en tanto el de las rifas solo llega al $11 \%$. 


\section{Discusión, conclusiones y recomendaciones}

Como se pudo percibir en las tres partes de la presentación de los resultados, las prácticas de ilegalidad poseen unas características particulares, considerando que estas se tejen en la cotidianidad de las comunidades, pero que también pueden estar aunadas a un fenómeno de la historia reciente en el contexto antioqueño, que tiene que ver con los actores armados que tienen presencia en los territorios. Los resultados de la investigación dejan ver, por ejemplo, cómo se ha configurado la institucionalidad para hacerle frente a esta problemática, teniendo dentro de este ejercicio un grupo operativo que diseña y organiza estrategias que permitan tener unas acciones de control a estas situaciones, lo que se vincula al cobro de impuestos y la regulación de la evasión.

Igualmente, en los resultados cuantitativos y cualitativos se observaron unas características particulares de la ilegalidad, en la que el chance manual y las rifas ilegales cobran relevancia en distintos territorios y tienen gran injerencia en la defraudación de los recursos departamentales por el no pago de impuestos. Así pues, teniendo en cuenta los resultados presentados anteriormente y la pregunta que aborda esta investigación: ¿cómo fortalecer la estrategia al control integral al monopolio rentístico de juegos de suerte y azar en el departamento de Antioquia?, es importante poner en discusión dos asuntos: Por un lado, la reflexión en cuanto a las prácticas de ilegalidad que se han presentado en el departamento y, por el otro, una descripción de la relación entre las prácticas de ilegalidad y la salud. 


\section{Sobre las prácticas de ilegalidad}

Las prácticas de ilegalidad en los juegos de suerte y azar configuran una afectación en un orden social complejo en la medida que tienen un impacto directo en la destinación de recursos en la salud, como se vio a la largo de este informe de investigación. Sin embargo, es válido reconocer el fenómeno de la ilegalidad como un asunto situado y contextualizado, es decir, que este no se presenta como unas acciones inocuas que emergen en el tiempo, sino que son construcciones socioculturales, históricas, políticas y económicas que tienen lugar en la región. De tal manera, que a continuación se presenta una reflexión frente a cómo la ilegalidad en los juegos de suerte y azar se relaciona con las dinámicas socioculturales, económicas y políticas de las distintas subregiones del departamento.

En el departamento de Antioquia se han identificado distintas modalidades de ilegalidad en los juegos de suerte y azar, de acuerdo a fuentes de la Secretaría de Hacienda de la Gobernación de Antioquia y de la Lotería de Medellín. Las prácticas más comunes de ilegalidad se exponen en la Figura 4.

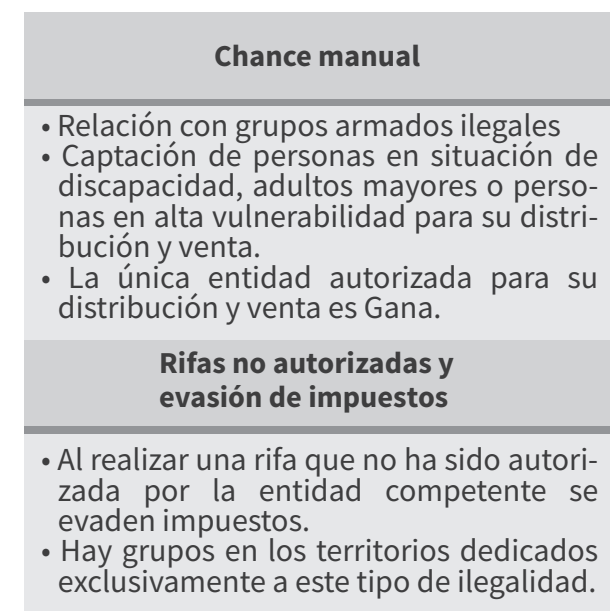

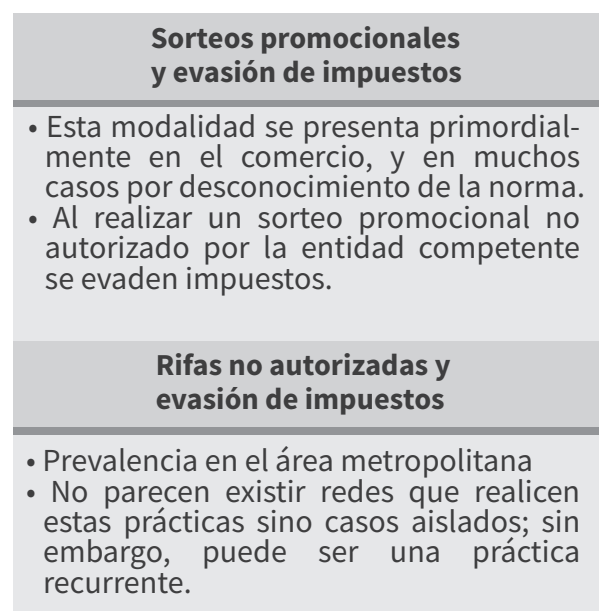

Figura 4. Prácticas más comunes de ilegalidad. Elaboración propia.

En este caso, dichas prácticas de ilegalidad se convierten en una dificultad en el recaudo del dinero que espera obtener la Gobernación, y esto, de acuerdo con todo el recorrido de este texto, tiene unas consecuencias y efectos en la 
finanación de la salud del régimen subsidiado, las personas no afiliadas y la investigación en salud, teniendo en cuenta que son estos los dineros que se destinana para ello. No obstante, se debe considerar que hay muchos factores que intervinen en la ilegalidad, es decir, hay que pensar estas prácticas desde posturas y reflexiones multidimensionales que permitan fortalecer las estrategias que se están llevando a cabo para combatir la ilegalidad desde la estructura, y que de esta manera se favorezca la financiación de la salud.

La estrategia que desarrolla el departamento de Antioquia y, en este caso, la Lotería de Medellín, tiene como objetivo fortalecer la inversión social en la región. Como se expresó en el capítulo anterior, a través del proceso de análisis estadístico y evaluación de impacto que se llevó a cabo durante la implementación de los operativos en contra de la ilegalidad en el departamento, durante el año 2019 se dejaron de percibir entre $\$ 15.647 .000 .000$ y $\$ 21.000 .000 .000$, una cantidad significativa de dinero que, como se dijo antes, tiene múltiples problemáticas y necesidades en materia de salud. Así, esta cantidad que no le ingresa al departamento deja de financiar el régimen subsidiado de salud y la investigación en salud, lo cual redunda no solo en el impacto económico y la defraudación del sistema de salud, sino en la calidad de vida de los habitantes de Antioquia, teniendo en cuenta que la desfinanciación se materializa en dificualtades en el acceso a la salud, en infraestructura, contratación de personal, entre otras situaciones.

En este caso, al plantear dicha reflexión se quiere dar cuenta de algunos aspectos que se pueden tener en consideración para favorecer el control de la ilegalidad en materia de las rentas departamentales, el cual se expresará en el siguiente cuadro:
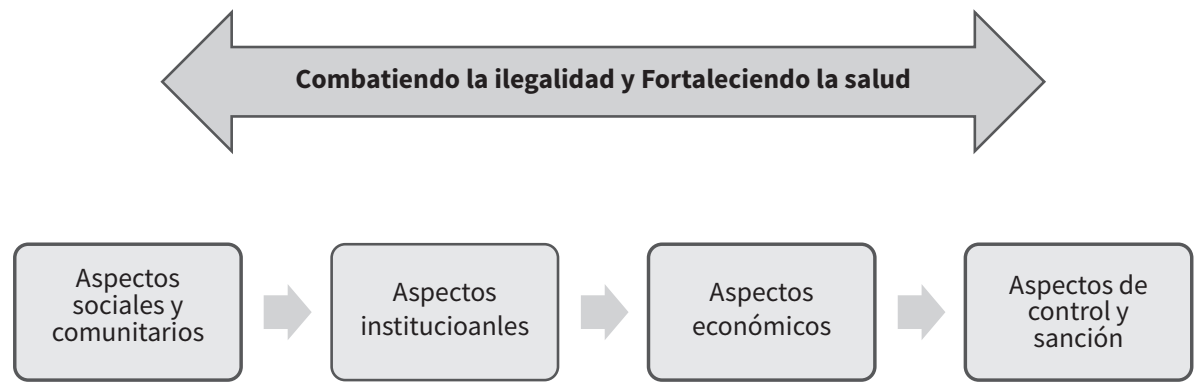

Figura 5. La ruta de la salud Antioqueña: combatiendo la ilegalidad y fortaleciendo la salud.

Elaboración propia. 
De manera que toda esta dinámica de las poblaciones dominadas por la ilegalidad tiene su eco en el control de las rentas, los impuestos, las apuestas y los juegos de suerte y azar. No es posible aislar algunos sectores de la economía cuando la cultura es una generalidad de comportamientos aprehendidos e impuestos a las poblaciones que hacen parte de la cultura antioqueña. La posición privilegiada que han obtenido estos actores armados en las relaciones de poder les ha permitido realizar una captura ilegal del Estado (López, 2012), por medio de la cual han logrado imponer leyes, regular conductas y formular políticas públicas. Así pues, la respuesta oficial de enfrentar las "presiones de los violentos" - aunada con la connivencia entre narcotráfico, actores armados, la Fuerza Pública y las administraciones locales, así como la persecución de los paramilitares contra las organizaciones sociales-conduciría a que el tejido social se deshilvanara y, como resultado de ello, las fronteras entre lo legal y lo ilegal y entre la política y la fuerza se vuelven cada vez más difusas (PNUD, 2011, p. 29).

Se requiere, entonces, de una sensibilización adecuada y orientada hacia la reflexión ético-moral de todos y cada uno de los ciudadanos en relación con el problema de la ilegalidad; un asunto que habita la imaginación en tanto se valida tanto lo ilícito como lo legal. Sin embargo, también se requieren acciones estatales, como la planeación, la ejecución y el control a partir de políticas incluyentes.

De acuerdo con los hallazgos, se puede concluir que las condiciones socioeconómicas y culturales presentes en el departamento de Antioquia, como la baja calidad de vida, la debilidad en la cobertura educativa y de salud, la presencia de grupos al margen de la ley y la falta de empleo, entre otras, son una explicación para legitimar el accionar en el campo de la ilegalidad, concretamente en lo que respecta a los juegos de suerte y azar. En este sentido, legitimar a partir de la ausencia de políticas orientadas a la satisfacción real de las necesidades básicas fundamentales de la población, de las acciones incorrectas como las correctas, o desde lo "malo como bueno", pero bajo las características socioculturales de la población antioqueña, son factores que permiten la existencia de estas conductas. 
Se podría decir, desde las características socioculturales, que en el imaginario del colectivo antioqueño se ha instalado la creencia de que la pujanza, la trampa, lo ilegal, es lo adecuado o debido para facilitar su desarrollo como persona o comunidad, fundamentado en la incapacidad del Estado para generar desarrollo social desde lo legal; situación que lleva al ejercicio de la actividad ilegal. En este sentido, existe un problema estructural de corte ético-moral que hay que entrar a resolver, problema que está en todas las esferas de la sociedad y que se haya institucionalizado. El imaginario colectivo está contaminado, en la medida en que se justifica lo malo como bueno, al lograr resolver sus necesidades a partir de las actividades ilícitas, como se expone a continuación:

Uno empieza a mirar socialmente lo que se mueve en el tema de las rifas, y uno como que empieza a pensar que el Estado, en muchos niveles, instancias y un Estado como el colombiano, uno ve que la plata se pierde, se la roban, que hay corrupción. Yo pienso y digo: es el mal menor. Me parece más digno que una persona venda una boleta porque tiene que mercar, a que se pierdan mil millones de pesos en un contrato del Estado que no lo desarrollaron adecuadamente y esa plata se perdió. (E3)

En este ejemplo se deja ver cómo se legitima la acción de ilegalidad al considerar que hay una situación de vulnerabilidad en la base. No con esto se quiere hacer una valoración moral de lo que ocurre en las comunidades, sino que es un intento por comprender las posturas de quienes están de ese dilema. En este sentido, se podría decir que las acciones ilegales que encierran los ilícitos se corresponden con una cultura donde se valora y aprueba el ejercicio de conductas no debidas y en nombre de un beneficio se atenta contra la norma. En el estudio "Valores, representaciones y capital social en Antioquia 2013", realizado por la Gobernación de Antioquia, se pone en evidencia lo dicho - a través de una encuesta aplicada- que:

Moralmente, la familia puede comportar un valor negativo cuando su bienestar se concibe como opuesto al bienestar general o cuando se avala la infracción de la ley y de las normas de convivencia en aras de favorecer o exculpar las conductas de los familiares. (Giraldo et al., 2013, p. 69) 
Otro asunto que tiene que ver con las prácticas ilegales y que afectan de manera directa los recaudos de recursos vitales para la proyección social, como es el caso de los impuestos en juegos de suerte y azar y su relación con la inversión en la salud de los antioqueños, se refiere a la educación y la falta de información de la población en torno a la importancia de acciones normativas cuando se trata de rifas, chances y juegos de azar generadas en el desconocimiento del porqué y para qué se establecen los impuestos, su destinación y su impacto de la inversión social, es decir, "aunque la lista de probables factores causales fue extensa, la clave mejor identificada como desencadenante de procesos como capital social, tolerancia, hábitos y proyecciones de vida fue la educación" (Giraldo et al., 2013, p. 37).

Es pertinente, entonces, reconocer los aportes de investigadores sociales cuando sugieren la necesidad de trabajar en procesos orientados a la construcción de prácticas legales, proceso que se debe abordar desde el componente educativo, como

La construcción de una cultura de la legalidad a partir de unas buenas prácticas. Atribuye a cada actor la debida responsabilidad en materia de las rentas departamentales, considerando que, si bien la institucionalidad es el ente encargado de velar por la organización y uso de los recursos, es el actor comunitario, la ciudadanía, que en últimas no solamente tiene la responsabilidad de cuidar sus propios recursos, sino también de hacer veeduría sobre su administración, teniendo en cuenta que, dichos recursos son usados en gran parte para fortalecer la inversión social en materia de salud y educación. (Usma y Zapata, 2017)

\section{¿Cuál es la relación con el sector salud?}

Uno de los aspectos más significativos cuando se habla de las consecuencias sociales y económicas de la ilegalidad en los juegos de suerte y azar es su relación con el sector de la salud, teniendo en cuenta que los recursos que se recogen por parte del monopolio rentístico de los juegos de suerte y azar tienen una destinación directa a los servicios de salud, tal y como se demuestra a continuación en el recorrido normativo asociado a los juegos de suerte y azar y a la salud. En este apartado se hará, en principio, una descripción del orden normativo que regula los juegos de suerte y azar en el sector salud, y luego una reflexión particular sobre los mismos. 
El Artículo 336 de la Constitución Política de Colombia dispone que las rentas obtenidas en el ejercicio de los monopolios de suerte y azar estarán destinadas exclusivamente a los servicios de salud, y establece que:

Ningún monopolio podrá establecerse sino como arbitrio rentístico, con una finalidad de interés público o social y en virtud de la ley.... La ley que establezca un monopolio no podrá aplicarse antes de que hayan sido plenamente indemnizados los individuos que en virtud de ella deban quedar privados del ejercicio de una actividad económica lícita... La organización, administración, control y explotación de los monopolios rentísticos estarán sometidos a un régimen propio, fijado por la ley de iniciativa gubernamental... Las rentas obtenidas en el ejercicio de los monopolios de suerte y azar estarán destinadas exclusivamente a los servicios de salud... Las rentas obtenidas en el ejercicio del monopolio de licores, estarán destinadas preferentemente a los servicios de salud y educación... La evasión fiscal en materia de rentas provenientes de monopolios rentísticos será sancionada penalmente en los términos que establezca la ley... El Gobierno enajenará o liquidará las empresas monopolísticas del Estado y otorgará a terceros el desarrollo de su actividad cuando no cumplan los requisitos de eficiencia, en los términos que determine la ley [...] En cualquier caso se respetarán los derechos adquiridos por los trabajadores. (Congreso de la República, 1991, art. 336)

Conforme al Artículo 336 de la Carta Magna, todo monopolio debe establecerse como arbitrio rentístico en virtud de la ley, la cual, a iniciativa del Gobierno, señalará el régimen propio respecto de su organización, administración, control y explotación. La Ley 643 de 2001, que establece el régimen propio, define el monopolio rentístico de juegos de suerte y azar, como "la facultad exclusiva del Estado para explotar, organizar, administrar, operar, controlar, fiscalizar, regular y vigilar todas las modalidades de juegos de suerte y azar" (art. $\left.1^{\circ}\right)$. La explotación, organización y administración de toda modalidad está sujeta a la ley citada, y a la reglamentación expedida por el gobierno nacional, "la cual es de obligatoria aplicación en todo el territorio del país, cualquiera sea el orden o nivel de gobierno al que pertenezca la dependencia o entidad administradora bajo la cual desarrolle la actividad el operador" (Congreso de la República, 2001, art. 2). Esta ley es perentoria al exigir la autorización previa para operar los juegos, pues faculta al Estado "para establecer las condiciones en las cuales los particulares pueden operarlos" (Congreso de la República, 2001, art. 1); "el 
monopolio será ejercido de conformidad con lo dispuesto en la presente ley (art. 2); "sólo podrán explotarse los juegos de suerte y azar en las condiciones establecidas en la ley de régimen propio y de conformidad con su reglamento" (art. 4), y está prohibida "la circulación, venta u operación de juegos de suerte y azar que no cuenten con la autorización de la entidad o autoridad competente" (art. 4). La ley 643 prevé de manera general, en desarrollo del Artículo 336 de la Carta "la organización, administración, control y explotación de los monopolios rentísticos estarán sometidos a un régimen propio, fijado por la ley de iniciativa gubernamental" que el Estado explota los juegos de suerte y azar directamente o mediante el concurso de los particulares.

El artículo 2 del Decreto 4142 de 2011 dispone que la Empresa Industrial y Comercial del Estado, Coljuegos, tendrá como objeto la explotación, administración, operación y expedición de reglamentos de los juegos que hagan parte del monopolio rentístico sobre los juegos de suerte y azar que, por disposición legal no sean atribuidos a otra entidad. El Decreto 1659 de 2002 regula lo concerniente a los recursos provenientes de los juegos de suerte y azar y su distribución.

En cuanto a las modificaciones relacionadas con las instituciones de control y fiscalización se identificaron distintos cambios. El primero está relacionado con la liquidación de Ecosalud S. A., y la cesión de sus bienes y funciones a la Empresa Territorial para la Salud (Etesa). Durante el funcionamiento de esta entidad, el control y fiscalización de los recursos eran competencia de la Dirección de Impuestos y Aduanas Nacionales (Dian) y del Consejo Nacional de Juegos de Suerte y Azar (CNJSA), a nivel nacional y territorial, respectivamente. Sin embargo, la liquidación de Etesa y posterior creación de Coljuegos significó un cambio en las funciones de control, administración y fiscalización de los recursos de los juegos de suerte y azar, tanto a nivel nacional como a nivel territorial. Desde el 2012, estas funciones estarían a cargo de Coljuegos para los juegos nacionales y del CNJSA estaría encargado únicamente de la vigilancia del cumplimiento de la reglamentación de los juegos de suerte y azar territoriales y, las funciones de inspección y control de las entidades que operan estos juegos estarían a cargo de la Superintendencia Nacional de Salud.

Por su parte, en la Ley 1393 de 2010 se definen las rentas de destinación específica para la salud, se adoptan medidas para promover actividades 
generadoras de recursos para la salud, para evitar la evasión y la elusión de aportes a la salud, se redireccionan recursos al interior del sistema de salud y se dictan otras disposiciones.

A través del artículo 61 del Plan Nacional de Desarrollo (PND), Ley 1955 de 2019, fueron establecidos los impuestos de juegos de azar destinados a la salud, determinándose de este modo que los operadores de juegos de suerte y azar localizados deban pagar por derechos de explotación un 12 \% sobre los ingresos brutos, menos la suma de los premios pagados, monto calculado sobre el total de los elementos de juego avalados en el contrato de concesión. Además, en el artículo 61 se explica que una vez se establezca la obligación de conectividad, se impondrán sanciones o decomisos de las máquinas a aquellas empresas que no cumplan la medida. A su vez, el PND expone en su artículo 49 que en las autorizaciones o concesiones para operar juegos de azar (que incluyen IVA) se realice un ajuste al valor de respectivo contrato, en el caso de alza en la tarifa del mencionado impuesto. Así mismo, se señala que la liquidación, ejecución y suscripción de contratos para la operación de todas las modalidades de juegos de azar no deberán ser gravados con ningún tipo de impuesto directo o indirecto.

Teniendo en consideración esta información de carácter normativo, vale la pena dar cuenta de cuál es la organización que se presenta de manera estructural en el sistema de salud colombiano, en términos de su financiación; es decir, de dónde salen los recursos y cuál es su destinación. Esto es importante en la medida en que los juegos de suerte y azar, como se ha dicho anteriormente, tienen gran responsabilidad en este proceso. En esta configuración del sistema, su dirección es de competencia de la entidad territorial, esto es, que tanto departamentos como municipios junto con la Superintendencia de Salud (Supersalud) tienen injerencia en los procesos de inspección, vigilancia y control del sector. En razón de ello, la recaudación del dinero en materia de juegos de suerte y azar es de competencia tanto del Gobierno nacional como de la entidad territorial designada por cada departamento, en este caso es de la Lotería de Medellín, como entidad que regula dicho monopolio (Orozco-Gallo, 2015).

A manera de contexto, vale la pena, entonces, presentar con claridad cuál es proceso de financiación de la salud en Colombia, de acuerdo con la propuesta de Orozco-Gallo (2015, p. 13): 

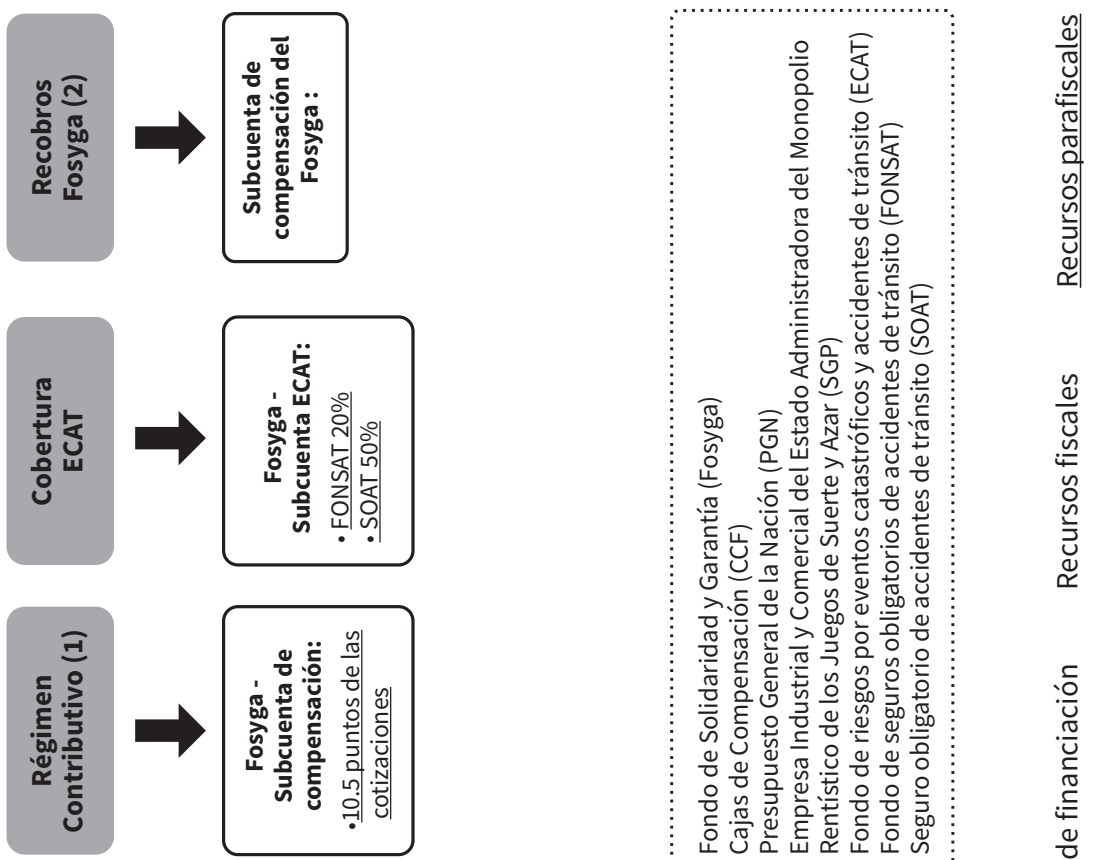

产式

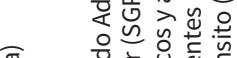

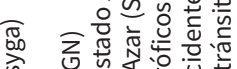

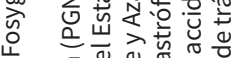

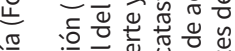

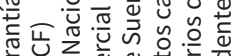
전너

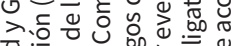

ரृ

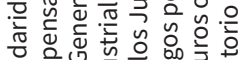

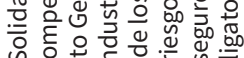

๙

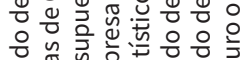

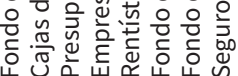

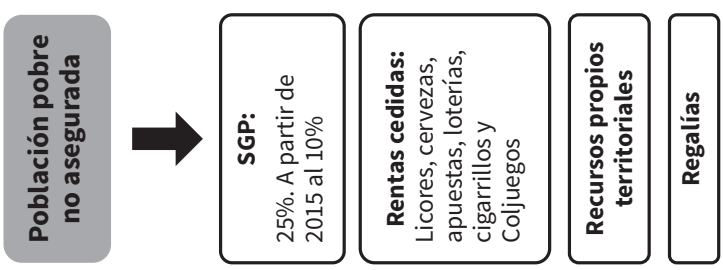

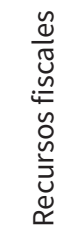
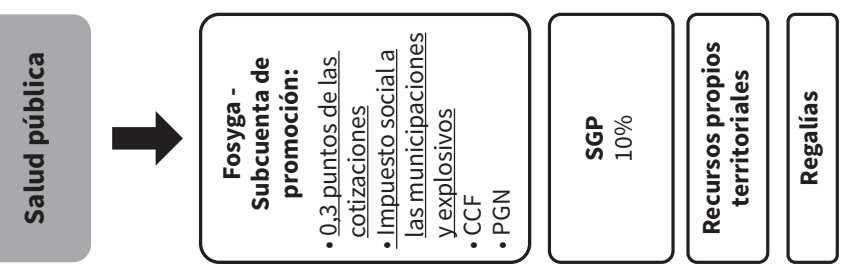

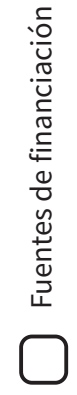

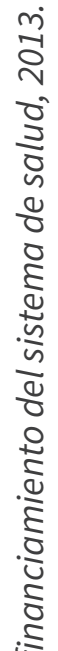
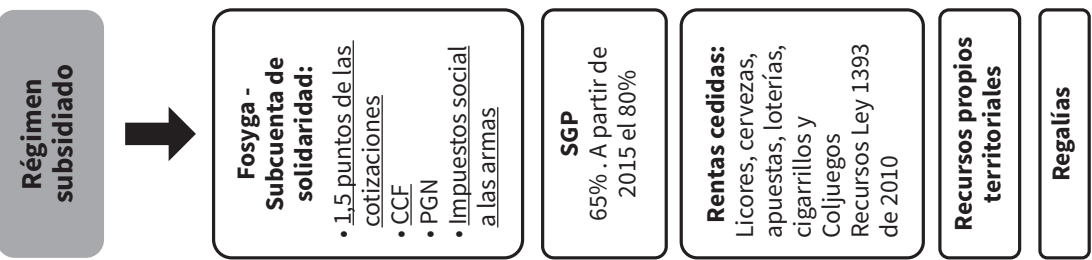

m

00

竎

논 은

岀 $\frac{0}{\bar{\pi}}$

ம

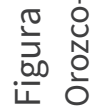


En la figura 6 es posible detallar cuál es el papel que tienen los juegos de suerte y azar en la financiación del sistema de salud, particularmente en cuanto al régimen subsidiado, que es "el mecanismo mediante el cual la población más pobre del país, sin capacidad de pago, tiene acceso a los servicios de salud a través de un subsidio que ofrece el Estado" (Ministerio de Salud y Protección Social, s. f., párr. 2) y, a su vez, también financia la población pobre no asegurada y la investigación en salud. En este caso, vale la pena precisar que la responabilidad directa de la renta del monopolio de los juegos de suerte y azar es con la salud de la población vulnerable y pobre del territorio colombiano. En capítulos anteriores se describió la composición demográfica y otras características del territorio antioqueño; de manera general, de acuerdo con el censo realizado en el año 2018 por el Departamento Administrativo Nacional de Estadística (Dane), Antioquia tiene aproximadamente un total de 5.974.788 habitantes, ${ }^{1}$ de los cuales el $48,3 \%$ son hombres y el $51,7 \%$ son mujeres.

Las características particulares del territorio antioqueño dotan de gran diversidad su economía: acceso; prestación de servicios; dinámicas; necesidades y problemáticas a nivel social, político, económico y cultural. Algunas de estas tienen relación directa con el sector de la salud. De un lado, por las problemáticas propias que aquejan y alteran el funcionamiento físico y mental de las personas y, de otro lado, en relación con los recursos y el equipamiento que debe tener el departamento para solventarlas.

Como se dijo antes, de acuerdo con las disposiciones normativas, la renta que sale de los juegos de suerte y azar está destinada a financiar la salud, particularmente de los usuarios del régimen subsidiado, las personas que no se encuentran aseguradas y la investigación en salud, de tal forma que, de acuerdo con cifras presentadas por la Secretaría Seccional de Salud y Protección Social (s. f.), en el capítulo de aseguramiento, con corte a septiembre del 2018, el total de personas afiliadas al régimen subsidiado era de 2.325 .579 personas, ${ }^{2}$ distribuidas por subregión como se muestra en la Tabla 6.

Se entiende por la población que fue censada de manera efectiva.

Entidades de afiliación de régimen subsidiado: Savia Salud, AIC, Emdisalud, Coosalud, Ecoopsos, Nueva EPS, Sura, Coomeva S. A., Salud Total, Cruz Blanca, Medimás EPS Subsidiada, Servicio Occidental, Sanitas S. A., Famisanar, Asmet Salud, Mutual Ser, Salud Vida S. A. 
Tabla 6. Afiliados al régimen subsidiado en antioquia.

\begin{tabular}{|l|c|}
\hline \multicolumn{1}{|c|}{ Municipio } & Total afiliados a septiembre del 2018 \\
\hline Magdalena Medio & 61.893 \\
\hline Bajo Cauca & 220.006 \\
\hline Urabá & 357.398 \\
\hline Nordeste & 130.287 \\
\hline Occidente & 145.372 \\
\hline Norte & 137.550 \\
\hline Oriente & 236.885 \\
\hline Suroeste & 214.521 \\
\hline Valle de Aburrá & 821.667 \\
\hline
\end{tabular}

Secretaría Seccional de Salud y Protección Social (s. f.).

Si bien estas cifras permiten dar cuenta de un buen nivel de asegurabilidad en el departamento, de acuerdo con el plan de desarrollo presentado por la actual administración, se ponen en evidencia algunos fenómenos con relación a la financiación.

Desde la dimensión del desarrollo económico, el sistema de salud presenta un déficit financiero que afecta a todos los actores del sistema: Proveedores, IPS, EPS, municipios y departamento, reflejado en fallas en los atributos de calidad, incremento de tutelas, fallas en la eficiencia de la prestación asistencial y mal servicio a los usuarios, que son su prioridad (Gobernación de Antioquia, 2016, p. 273).

Es necesario reconocer algunos aspectos sobre cómo la ilegalidad que se desarrolla en el marco de los juegos de suerte y azar contribuye a dichas dificultades en la financiación de la salud y con ello de sus servicios. 


\section{Conclusiones}

La ejecución de investigaciones académicas alrededor de los proyectos públicos permite dejar consignadas en el tiempo experiencias y características que ayudan al mejoramiento de los procesos institucionales y comunitarios. Se logró evidenciar a través de este ejercicio que la estrategia adelantada para el fortalecimiento de los juegos de suerte y azar en el departamento de Antioquia incidió en el control de la ilegalidad en los municipios y, además, logró reconocer dinámicas propias de las comunidades que son recurrentes y están normalizadas.

Este producto es un antecedente para futuras propuestas de control de la ilegalidad, necesario para formular procesos basados en las formas contextuales de las subregiones del departamento, con sus características culturales, las prácticas de ilegalidad registradas y la defraudación económica. Además, permite fortalecer los métodos y las actividades según la experiencia, la información ya identificada y relacionar las dificultades, el control estatal y las particularidades sociales con la aplicación de procedimientos institucionales.

Así pues, las prácticas de ilegalidad reconocidas alrededor de la renta del monopolio de juegos de suerte y azar se puntualizan específicamente en las rifas ilegales, luego en el chance manual, los sorteos promocionales no autorizados y, por último, en la lotería falsificada, en la que es común reconocer la evasión fiscal como la defraudación más recurrente. Igualmente, se encontraron algunas dificultades en el desconocimiento de la norma 
respecto al chance ilegal por parte de los consumidores, brechas normativas que no permiten que pequeños y medianos establecimientos logren formalizar sorteos promocionales, y la lotería falsificada no presenta aprehensiones en el recorrido del tiempo de la investigación. Se podría decir que las prácticas de ilegalidad se lograron observar desde varias perspectivas: una desde la institucionalidad y el control, otra desde el grupo de personas que opera la modalidad de ilegalidad en los juegos y, por último, desde el consumidor. En las entrevistas y en las encuestas realizadas hay similitudes en algunas características técnicas de ejecución en la ilegalidad, pero se logran además contrastar los pensamientos respecto a la legitimización de las prácticas. En este sentido, los participantes concordaron que es necesaria una relación directa entre instituciones y comunidades para fortalecer los lazos, las oportunidades de conversación, la capacitación y sensibilización y el apoyo, según la caracterización de cada municipio.

Se identificó que los trabajos con datos cuantitativos en los proyectos ejecutados por las instituciones públicas resultan ser de gran importancia para evaluar la ejecución de los presupuestos, establecer estadísticas sobre temas específicos, incentivar proyectos, replicar estrategias y ejecutar control sobre procesos en cualquier modalidad. Dejar constancia escrita sobre la defraudación y los efectos que genera la ilegalidad en un territorio permite identificar cuánto dinero se deja de percibir para la inversión social y hacer comparativos por periodos determinados y estudios socioeconómicos sobre las comunidades.

Es así que, finalmente, se hizo una reflexión sobre la ilegalidad y su impacto en el sector salud, evidenciando que los impuestos que no fueron recaudados a causa de la ilegalidad tenían una destinación específica para mejorar el sistema subsidiario del departamento. Por lo tanto, se hace un llamado para que el fortalecimiento de la cultura de la legalidad sea una forma de reconocer las implicaciones de la defraudación, las brechas normativas y del desconocimiento. 


\section{Recomendaciones}

A manera de recomendaciones, y teniendo en cuenta la multicausalidad de la ilegalidad, las particularidades de las subregiones y los efectos que estas prácticas tienen sobre la financiación de la salud, las estrategias que se puedan implementar para controlar las prácticas ilegales en los juegos de suerte y azar buscan que se puedan intervenir desde distintos ámbitos; de manera que, a la luz de éstos, a continuación se darán algunas pautas que pueden fortalecer la intervención y actuación institucional sobre la ilegalidad en el monopolio rentístico de juegos de suerte y azar:

\section{Importancia de la medición de impacto}

A partir del desarrollo de esta investigación se pudo identificar que, para los proyectos de carácter institucional que involucran temas de defraudación o incidencia económica, sería de suma importancia optar por adicionar estudios de impacto con elementos cuantificables que pueden relacionarse con las generalidades del contexto en el que se desarrollan algunos proyectos, e identificar características y rutas alrededor de lucha contra la ilegalidad.

La evaluación de impacto se desarrolla bajo la relación del ámbito socioeconómico; e incluye, no resultados que se previeron, sino también aquellos que no. Igualmente, contempla los efectos tanto positivos como negativos que se pudieran presentar luego de la implementación de un determinado programa o proyecto en un grupo social o una comunidad (Libera, 2007, p. 4). Se reconoce que el significado del impacto social varía de 
un lugar a otro, de un proyecto a otro, de una comunidad a otra y hasta dentro de los grupos de una misma comunidad (Vanclay, 2002, p. 112) y, por lo tanto, es necesario tener presente el proyecto a evaluar y el contexto del territorio en el cual se va a realizar el estudio.

Para futuras ocasiones es importe tener en cuenta la evaluación de impacto porque puede ser una forma para realizar una valoración imparcial sobre lo que se pueda avanzar en este proceso de fortalecimiento de los juegos de suerte y azar; es decir, en términos económicos y sociales se facilita la realización, a través de los resultados, de ejercicios tales como la toma de decisiones, la evaluación y el control. Estas actividades engloban tanto la evaluación de los funcionarios públicos que laboraron en pro del objetivo de la estrategia hasta el desarrollo del proyecto en general.

En los juegos de suerte y azar hacer referencia a la medición de la administración - recaudo, fiscalización, liquidación, cobro y devolución de carácter regional, según lo dispuesto en la Ordenanza 29 de 2017-, significa analizar los avances del proyecto en ejecución. Es decir, si se realiza una medición de impacto se puede complementar la evaluación y el control, se pueden evidenciar los niveles de riesgo respecto a los resultados esperados y, también, algunos se pueden prever, como lo menciona Libera (2007), aunque también pueden ser, por el contrario, un factor sorpresa. Hacer una medición de impacto de esta estrategia adelantada por la institución Lotería de Medellín permite conectar directamente con el desarrollo económico del departamento; si el impacto no es positivo significaría que puede existir una coyuntura económica, y se podrían proponer recomendaciones y acciones estratégicas; pero también es posible que si el impacto es positivo, la estrategia como tal permitiría el sano desarrollo socioeconómico del territorio antioqueño, mientras ejerce prácticas replicables en el tiempo contra la ilegalidad.

\section{Aspectos sociales y comunitarios}

A partir del ejercicio de buenas prácticas dentro de las comunidades es posible tejer relaciones de colaboración entre la institucionalidad y los territorios, y así, disminuir la ilegalidad y fortalecer la renta de juegos de suerte y azar. Esas 
prácticas pueden desarrollarse por medio de estrategias de sensibilización social y comunitaria sobre varios apectos, entre ellos, la salud, tema descrito anteriormente, donde se aborda la importancia en los aspectos económicos y sociales de la ejecución de los presupuestos en el sector, los beneficios para los centros de salud y servicios hospitalarios con mayor inversión. Además, la comunidad debe conocer los riesgos que conlleva incurrir en actividades de juego en exceso y realizar prácticas de ilegalidad que tienen consecuencias penales y económicas.

Por otra parte, se requiere la formación y la capacitación a comerciantes y personas autorizadas para evitar la interacción con las bandas criminales y sus modus operandi. Es importante que las personas involucradas en el desarrollo de juegos de suerte y azar puedan identificar las características legalmente aceptadas para cada una de las modalidades del monopolio, y comprendan además las responsabilidades en las que incurren en relación con los impuestos. También es importante que, según el contexto del municipio, la comunidad conozca y reconozca las dinámicas territoriales en torno a la renta y se establezca una relación institución-comunidad, para que sean ejecutadas de manera legal y con miras a la inversión social en salud.

Hacer jornadas pedagógicas. Dentro de las comunidades se identificaron características y realidades contextuales alrededor de prácticas de juegos de suerte y azar específicas y, también, prácticas de ilegalidad recurrentes. Es importante llevar a los territorios estrategias orientadas a sensibilizar y educar a la población en torno a qué son los impuestos, por qué existen, quién los impone, quién los recauda y para qué, de esta manera, es posible tejer procesos que ayuden a desnaturalizar dentro de la cotidianidad prácticas al margen de la ley. Las jornadas pedagógicas pueden permitir a la institución establecer una relación de colaboración con los territorios a partir de tales ejercicios, y no solo se establecería un tema específico sobre el tributo, sino también sobre los riesgos penales y económicos que conlleva la ilegalidad y, además, sobre cultura de la legalidad e identificación de prácticas ilícitas.

Se podría decir que la información transmitida para la comunidad por medio de equipos de comunicación permite fortalecer los procesos de los operativos, porque las personas que habitan estos territorios podrán comprender lo que significa para la inversión social el accionar en contra de las bandas delictivas. 


\section{Aspectos institucionales}

El departamento de Antioquia cuenta con las facultades para asegurar el efectivo cumplimiento de las obligaciones a cargo de los concesionarios o destinatarios autorizados para operar. Se entiende que, a través de los organismos de presión (fuerza del Estado, Policía, Ejército, etc.), podrá vigilar a concesionarios autorizados y controlar y sancionar a quienes incurran en la ejecución del negocio sin la debida autorización de quien le compete.

La institución, a través de la Ordenanza 29 de 2017, debe construir estrategias situadas contextualmente, por su facultad y por el acercamiento a los municipios del departamento durante este periodo. La estrategia debe trabajar, por medio de los operativos, algunos procesos de recolección de información que faciliten estudios de medición de impacto y, por ende, se haga posible plasmar en el tiempo la documentación que pueda ser utilizada en proyectos replicables en todo el departamento o dentro de otros territorios. Es importante que las instituciones apoyen procesos de investigación para fortalecer la recolección de la información, la sistematización de experiencias y la medición de impacto, estableciendo indicadores de impacto socio-económico.

Por último, tal como se recomienda en los aspectos sociales, comunitarios y pedagógicos, es importante establecer una relación institución-comunidad que fortalezca los procesos en contra de la ilegalidad, pero que también posibilite la confianza pública, la responsabilidad social y la transparencia de los proyectos. De esta manera, será posible construir en el tiempo procesos reconocidos públicamente por la comunidad, los distribuidores, comerciantes y funcionarios públicos.

\section{Aspectos económicos}

Incentivar una cultura tributaria es una recomendación que engloba varios aspectos: El recaudo de los impuestos, la destinación de la renta, el fortalecimiento de los ingresos regionales y el desarrollo social de la región. El efecto económico que genera la evasión de impuestos y, por ende, el poco recaudo, se dan a partir del desconocimiento de la norma y la destinación de los tributos y de la poca cultura tributaria del departamento. Fortalecer esa 
característica en las comunidades permitirá financiar aspectos necesarios para el desarrollo social.

También es importante que en los juegos de suerte y azar se implementen controles con mayor periodicidad en los establecimientos comerciales del territorio. Aunque se presente un grupo de operativos encargado de evitar y reconocer prácticas de ilegalidad en las modalidades del monopolio, es importante incentivar visitas que vayan en pro de revisar, retroalimentar y direccionar los procesos de los comerciantes. Incrementar el ingreso de los tributos para el departamento también puede incentivar el aumento del ingreso familiar. La informalidad en los territorios lleva al enriquecimiento ilícito de las bandas criminales, mas no de las personas involucradas en el menudeo.

\section{Aspectos de control y sanción}

En esta clase de aspectos, las recomendaciones se engloban tanto en términos legales y normativos como de articulación. La articulación entre las entidades debe permitir la vigilancia y el control territorial y reconocer elementos de sanción en torno a la ilegalidad. Es importante contrarrestar el desconocimiento de las leyes mientras se realizan jornadas pedagógicas para la formación de los funcionarios públicos que realizan los operativos, los comerciantes, los distribuidores autorizados y la comunidad en general. De esta manera, se podrán identificar el nivel de cumplimiento y el nivel de aceptación de manera significativa a través de dichas acciones. También es importante que las normas permitan que las instituciones que acompañan a los grupos que llevan a cabo operativos permanezcan el mayor tiempo con ellos y los procesos no se vean versados por los tiempos. Además, es importante que el equipo que intenta contrarrestar las prácticas ilegales en nombre de la institución sea más grande y pueda abarcar más territorios al mismo tiempo. 


\section{Referencias}

Alonso, J., y Gallego, A. (2010). Concesión del monopolio de juegos de apuestas y azar en el Valle del Cauca. Estudios Generales, 26(116), 211-223.

Aramburo, C., Bejarano, O., Escobar, J., y Vásquez, N. (2007). Norte, desarrollo regional: una tarea común universidad-región. Medellín: Editorial Universidad de Antioquia.

Asamblea Departamental de Antioquia. (31 de agosto de 2017). Ordenanza 29, por medio de la cual se establece el Estatuto de Rentas del departamento de Antioquia. Medellín: Asamblea Departamental de Antioquia.

"Autoridades desarticulan red de apuestas ilegales, que tenían presencia en varios municipios del Oriente". (18 de mayo de 2017). DiariOriente.com https://diarioriente.com/altiplano/la-ceja/autoridades-desarticulanred-apuestas-ilegales-tenian-presencia-varios-municipios-deloriente.html

Barrera, J., y Hessdörfer, A. (2012). El engaño como conducta típica en la defraudación tributaria: puntos de contacto y asimetrías entre el régimen infraccional y penal. Revista de Derecho, (11), 11-22.

Bernal, L. (2018). Minería de oro en el nordeste antioqueño: una disputa territorial por el desarrollo. Gestión y Ambiente, 21(2), 74-85. https:// doi.org/10.15446/ga.v21n2supl.77865

Cámara de Comercio de Medellín. (2019). Perfiles socioeconómicos de las subregiones de Antioquia. Medellín: Cámara de Comercio. 
Cámara de Comercio del Oriente Antioqueño. (2018). Concepto económico del oriente antioqueño-2018. https://www.ccoa. org.co/Portals/0/Biblioteca\%20virtual/Publicaciones $\% 20$ regionales/2018/Concepto\%20 econ\%C3\%B3mico\%202018. pdf?ver=2019-02-01-105326-537

Céspedes, M., y Osorio, J. (2010). Identificación de estilos gerenciales administrativos vigentes y necesidades derivadas de formación en las empresas del sector servicios, subsector juegos de azar en el Área Metropolitana centro-occidente. (Tesis de pregrado, Universidad Tecnológica de Pereira). Pereira. http://repositorio. utp.edu.co/dspace/bitstream/handle/11059/2016/65842C422. pdf?sequence=1\&isAllowed=y

"Chance ilegal en Antioquia". (13 de mayo de 2012). Teleantioquia Noticias. [Video en Youtube]. https://www.youtube.com/watch?v=ljxmGWcy8pU Choclán, J. (2016). La aplicación práctica del delito fiscal: cuestiones y aplicaciones. Barcelona: Bosh.

Comfenalco Antioquia. (2018). Dinámica laboral. Agencia de gestión y colocación de empleo Comfenalco. https://www.comfenalcoantioquia. com.co/ wcm/ connect/ 06d73168-a871-46e8-af6c-b5a4926dcb0d/ Informe+ Bajo+ Cauca+ \%28Julio+ 2018\%29. pdf? MOD= AJPERES $\& C V I D=n 3 f h c v H \& C V I D=n 3 f h c v H \& C V I D=n 3 f h c v H \& C V I D=n 3 f h c v H$

Congreso de la República de Colombia. (2001). Ley 643 de 2001. Régimen propio del monopolio rentístico de juegos de suerte y azar.

Congreso de la República de Colombia. (1991). Constitución Política de Colombia. Bogotá.

Congreso de la República de Colombia. (2010). Ley 1393 de 2010. Rentas de destinación específica para la salud.

Corporación Autónoma Regional del Centro de Antioquia (Corantioquia). (2017). Caracterización de las condiciones sociales, culturales y económicas. http://www.corantioquia.gov.co/SiteAssets/PDF/Tematicas/Agua/ POMCA-AURRA/2.4.Caract_SocialEcoCultural2.pdf

Corporación Autónoma Regional del Centro de Antioquia (Corantioquia). (2018). Formulación del plan de manejo ambiental del sistema acuífero del Magdalena Medio antioqueño. http://www.corantioquia.gov.co/ ciadoc/AGUA/AIRNR_110_CNT1706_46_2017_02DIAGNOSTICO\%20 PARTICIPATIVO.pdf 
"Chance ilegal en Antioquia". (7 enero de 2015). Cosmovisión Noticias. [Video en Youyube]. https://www.youtube.com/watch?v=dzhlqXa4ZPM

Dalle, P., Boniolo, P., Sautu, R., y Elbert, R. (2005). Manual de metodología. Construcción del marco teórico, formulación de los objetivos y elección de la metodología. Buenos Aires: Clacso.

Delgado, M. (mayo de 2012). Algunas reflexiones en torno a la legalidad, cultura jurídica y comportamiento ciudadano. En Contribuciones a las Ciencias Sociales. [Internet]. Universidad del Oriente, Cuba. http://www.eumed. net/rev/cccss/20/

Díaz-Bravo, L., Torruco-García, U., Martínez-Hernández, M., y Varela-Ruiz, M. (2013). La entrevista, recurso flexible y dinámico. Elsevier, 2(7), 154-161. "Diez mil millones de pesos de chance ilegal se están quedando en manos de las bandas criminales". (2015). Hora 13 Noticias. [Video en Youtube]. https://www.youtube.com/watch?v=etkV-jej-10

Echeverría, R., Fuentes, J., y Castillo, T. (2011). Los juegos de suerte y azar como problema en la investigación social en México: balance preliminar y perspectivas. Revista Científica de Investigaciones Regionales, 33(2), 35-72.

Empresa Territorial para la Salud (Etesa) (2003). Cuatro estudios sobre juegos de suerte y azar en Colombia. Yumpu. https://www.yumpu.com/es/ document/read/13596537/cuatro-estudios-sobre-juegos-de-suerte-yazar-en-colombia

Fariñas, M. (2011). Normas de papel. La cultura del incumplimiento. Eunomía. Revista en Cultura de la Legalidad, (1), 185-188.

Figueredo, C. (2001). El monopolio de juegos de suerte y azar y su incidencia en la hacienda local. (Tesis de pregrado, Universidad de la Sabana). Bogotá. https://1library.co/document/zpnlw2oy-monopolio-juegossuerte-azar-incidencia-hacienda-local.html

Finkeros (30 de octubre de 2013). La región del Magdalena Medio. ABC del Finkero. http://abc.finkeros.com/la-region-del-magdalena-medio/

García, M. (22 de diciembre de 2014). Chance ilegal sigue jugándose en barrios y municipios paisas. El Tiempo. https://www.eltiempo.com/archivo/ documento/CMS-15011958

García, P., Buil, P., y Solé, M. (2016). Consumos de riesgo: menores y juegos de azar online. El problema del "juego responsable", Política y Sociedad, 53(2), 551-575. 
Giraldo, J., Casas, A. Méndez, N., y Eslava, A. (2013). Valores, representaciones y capital social en Antioquia. Medellín: Editorial Artes y Letras.

Gobernación de Antioquia. (2016). Plan de desarrollo, "Acreditamos tu salud" 2016-2019.https://www.hcup.gov.co/assets/files/miscelaneos/ pls20181114102123-gr.pdf

Gobernación de Antioquia. (s. f.). Estadísticas aseguramiento, septiembre 2018. Secretaría Seccional de Salud y Protección Social. https://www.dssa. gov.co/index.php/estadisticas/aseguramiento

Gómez, Y., Usma, L., Zapata, L. Echavarría, R., y Giraldo, L. (2017). El control integral a las rentas ilícitas: Una experiencia de buenas prácticas en el departamento de Antioquia. Medellín: Tecnológico de AntioquiaGobernación de Antioquia.

Gómez, Y., Usma, L., Zapata, L., Zapata, M., Echavarría, R., y Ceballos, L. (2019). Las rentas departamentales en Antioquia: dimensiones de la ilegalidad, impacto y recomendaciones. Medellín, Colombia: Tecnológico de Antioquia-Secretaría de Hacienda, Gobernación de Antioquia.

Gómez, Y., Usma, L., Zapata, L., Ceballos, L., y Echavarría, R. (2019). Las buenas prácticas de legalidad: instituciones responsables. Medellín: Sello Editorial Publicar-T.

Gonzalo, J., Rico, D., Wiesner, D., Goyoneche, L., Trespalacios, D., y Urrutia, D. (2018). Caracterización y estimación del mercado ilegal de juegos de suerte y azar en Colombia. https://www.repository.fedesarrollo.org.co/ bitstream/handle/11445/3754/Repor_Septiembre_2018_Zapata_et_ al.pdf?sequence $=3 \&$ isAllowed $=y$

"Ilegalidad en juegos de suerte y azar mueve unos $\$ 800.000$ millones". (21 de agosto de 2019). Caracol Radio. https://caracol.com.co/ radio/2019/08/21/economia/1566422942_051392.html

Instituto de Ciencias Políticas Hernán Echavarría Olózaga. (2009). Juegos de suerte y azar. Observatorio Legislativo. Boletín N.o 139. https:// www.academia.edu/4642319/Juegos_de_suerte_y_azar_Ponentes_ representantes

Instituto Popular de Capacitación (IPC). (2017a). Nordeste Antioqueño. http:// ipc.org.co/index.php/regiones/nordeste-de-antioquia/

Instituto Popular de Capacitación (IPC). (2017b). Norte de Antioquia. http://ipc. org.co/index.php/regiones/norte-de-antioquia/ 
Instituto Popular de Capacitación (IPC). (2017c). Urabá Antioqueño. http://ipc. org.co/index.php/regiones/uraba-antioqueno/

"La Fiscalía ocupa bienes avaluados en más de 50 mil millones de pesos, producto del chance ilegal". (2016). Hora 13 Noticias. [Vídeo en Youtube]. https://www.youtube.com/watch?v=He0XNhBxWDQ

Legaz, L. (1958). Legalidad y legitimidad. Revista de Estudios Políticos. (101), 5-24. Centro de Estudios Políticos y Constitucionales, España.

Libera, B. (2007). Impacto social y evaluación de impacto. La Habana: Acimed. López, D. (2014). La "cultura de la legalidad" como discurso académico y como práctica política. Un reporte desde América Latina. En I. Wences, R. Conde y A. Bonilla (Eds.), Cultura de la legalidad en Iberoamérica: desafíos y experiencias (pp. 47-82). San José, Costa Rica: Perspectivas Digital S. A.

Manrique, A. (2010). Análisis teórico de los juegos de azar como construcción cultural. (Tesis de pregrado, Pontificia Universidad Javeriana), Bogotá. https://repository. javeriana.edu.co/bitstream/handle/10554/5474/tesis 488 . pdf;jsessionid=8653A0C3B5EB4C5F1DF6F440DE537D02? sequence $=1$

Ministerio de Justicia de Colombia (Minjusticia). (2011). Decreto 4142 de 2011. Empresa Comercial del Estado Administradora del Monopolio Rentístico de los Juegos de Suerte y Azar, Coljuegos.

Ministerio de Justicia de Colombia (Minjusticia). (2002). Decreto 1659 de 2002. Distribución y giro oportuno por parte de Etesa de los recursos.

Ministerio de Justicia de Colombia (Minjusticia). (2019). Ley 1955 de 2019. Plan Nacional de Desarrollo 2018-2022.

Ministerio de Salud y Protección Social de Colombia. (s.f.). Régimen subsidiado. https://www.minsalud.gov.co/salud/Paginas/ R\%C3\%A9gimenSubsidiado.aspx

Minuto 30. (2016). El chance ilegal le genera al departamento pérdidas superiores a los 90 mil millones de pesos. https://www.youtube.com/ watch?v=bUQTziiY6Jo

Morales, M., Arévalo, N., y Díaz, G. (2016). Análisis de los tributos generados por la explotación de juegos de suerte y azar en Bogotá. (Tesis de posgrado). Universidad Piloto de Colombia. Bogotá. http://polux.unipiloto.edu. co:8080/00003068.pdf 
Orozco-Gallo, A. J. (2015). Un análisis del gasto público en salud de los entes territoriales colombianos. Cartagena: Banco de la República.

Padró, B. (2015). El juego de azar como paradigma epistemológico: cuestiones de filosofía y poética. Ludus Vitalis, 23(43), 231-246.

Peña, T., y Pirela, J. (2007). La complejidad del análisis documental. Información, cultura y sociedad: Información, Cultura y Sociedad: Revista del Instituto de Investigaciones Bibliotecológicas, (17), 55-81.

Pérez, S., Alcalá, B., Pérez, G., y Yahón, A. (2018). Juventud y juegos de azar. Una visión general del juego en los jóvenes. Madrid: Instituto de la Juventud. Pinzón, L. (26 de diciembre de 2018). Sector salud perdió cerca de $\$ 20.000$ millones por apuestas ilegales. RCN Radio. https://www.rcnradio.com/bogota/ sector-salud-perdio-cerca-de-20000-millones-por-apuestas-ilegales

Prieto, M. (1994). Medidas para mejorar el cumplimiento de las obligaciones tributarias: Las amnistías fiscales. Anales de Estudios Económicos y Empresariales, (9), 219-242.

Programa de las Naciones Unidas para el Desarrollo (PNUD). (2011). Regiones en conflicto. Comprender para transformar. Bogotá: PNUD.

"Quince personas capturadas por vender chance ilegal en Antioquia". (27 de junio de 2019). Teleantioquia Noticias. [Video en Youtube]. https:// www.teleantioquia.co/featured/15-personas-capturadas-por-venderchance-ilegal-en-antioquia/

Reyes, A., Amaya, L., y Pedraza, W. (2011). El despojo en tierras por paramilitares en Colombia. Antioquia. Ideazpaz. http://www.ideaspaz.org/tools/ download/52149

Rezzoagli, B. (2009). Ilícitos tributarios. Diferenciación entre evasión, defraudación y elusión fiscal. Sistema de Universidad Abierta. UNAM. http://www.derecho.duad.unam.mx/amicus-curiae/descargas/10_ feb_09/ILICITOSpdf.pdf

Ricoy, C. (2006). Contribución sobre los paradigmas de investigación. Educação, 31(1), 11-22.

Sharlot, V. (2016). La responsabilidad penal de las personas jurídicas en el delito de defraudación tributaria. (Tesis de pregrado). Universidad Central del Ecuador http://www.dspace.uce.edu.ec/bitstream/25000/6285/1/TUCE-0013-Ab-180.pdf

TonondeToscano,G.(2013).Laintegracióndemétodosdeinvestigaciónenciencias sociales: La triangulación y los métodos mixtos. El Colegio Mexiquense. 
http://www2.cmq.edu.mx/libreria/index.php?option=com_ docman\&view=download\&alias $=894-$ di $1350530 \&$ category_ slug=docum-investigacion\&ltemid=189\&accept_license=1Parte +2 . pdf?MOD=AJPERES

Universidad de Antioquia. (2012). Propuestas programáticas y perfil político de los mandatarios de Antioquia 2012-2015. Mónica Cecilia Santa R., Coordinación General. http://www.udea.edu.co/wps/wcm/connect/ udea/4d7ae0cc-b102-4f7f-ab36-a92ffdb1989b/Perfil+Politico+Mandat arios+Antioquia+2015+-+Parte+1+(1).pdf?MOD=AJPERES

Usma, L., y Zapata, L. (2018). La cultura de la legalidad en las rentas del departamento de Antioquia como un ejercicio de buenas prácticas desde las acciones comunitarias. En Y. Gómez (Ed.). Observatorio Público: experiencias, tendencias y desafíos. Líneas de investigación para explorar los campos de las ciencias administrativas y de gestión, económicas y contables (pp. 430-449). Medellín: Sello Editorial Publicar-T.

Usma, L., y Zapata, L. (2017). La cultura de la legalidad como un ejercicio de buenas prácticas en el departamento de Antioquia. En-Contexto, 5(7), 157-177.

Vacchiano, M., y Mejía, C. (2017). Reflexiones sobre los juegos de azar en la sociedad contemporánea: hacia una biografía del riesgo. Athenea Digital. Revista de Pensamiento e Investigación Social, 17(2), 79-94.

Vanclay, F. (2002). Conceptualizing Social Impacts. Environmental Impact Assessment Review, 22(3), 183-211.

Vega, A. (2015). Problemas alrededor del recaudo de los derechos de explotación en el monopolio rentístico de los juegos de suerte y azar en Colombia. (Tesis de Maestría, Universidad de los Andes, Bogotá: https:// repositorio.uniandes.edu.co/bitstream/handle/1992/13397/u722288. pdf?sequence $=1$

Vega, O. (2002). Surgimiento de la teoría matemática de la probabilidad. Apuntes de Historia de las Matemáticas, 1(1), 54-62.

Velásquez, C. (30 de septiembre de 2016). Occidente: la ruta del sol y de la fruta. El Mundo. https://www.elmundo.com/portal/noticias/territorio/ occidente_la_ruta_del_sol_y_de_la_fruta.php\#.XdNyDIdKjIV

Villoria, M. (2014). Estado de derecho, cultura de la legalidad, y buena gobernanza. En I. Wences, R. Conde y A. Bonilla (eds). Cultura de la 
legalidad en Iberoamérica: desafíos y experiencias (pp. 83-118). San José, Costa Rica: Perspectivas Digital S. A.

Yogonet. (2018). Coljuegos allanó 10 locales de juego ilegal y decomisó más de mil productos. https://www.yogonet.com/latinoamerica/ noticias/2018/06/21/76608-coljuegos-allano-10-locales-de-juegoilegal-y-decomiso-mas-de-mil-productos

Zapata, L., y Usma, L. (2019). Los fraudes en las rentas departamentales: una mirada desde la institucionalidad a las dimensiones social, económica, legal y normativa. En-Contexto, 7(11), 213-229. 


\section{Anexos}




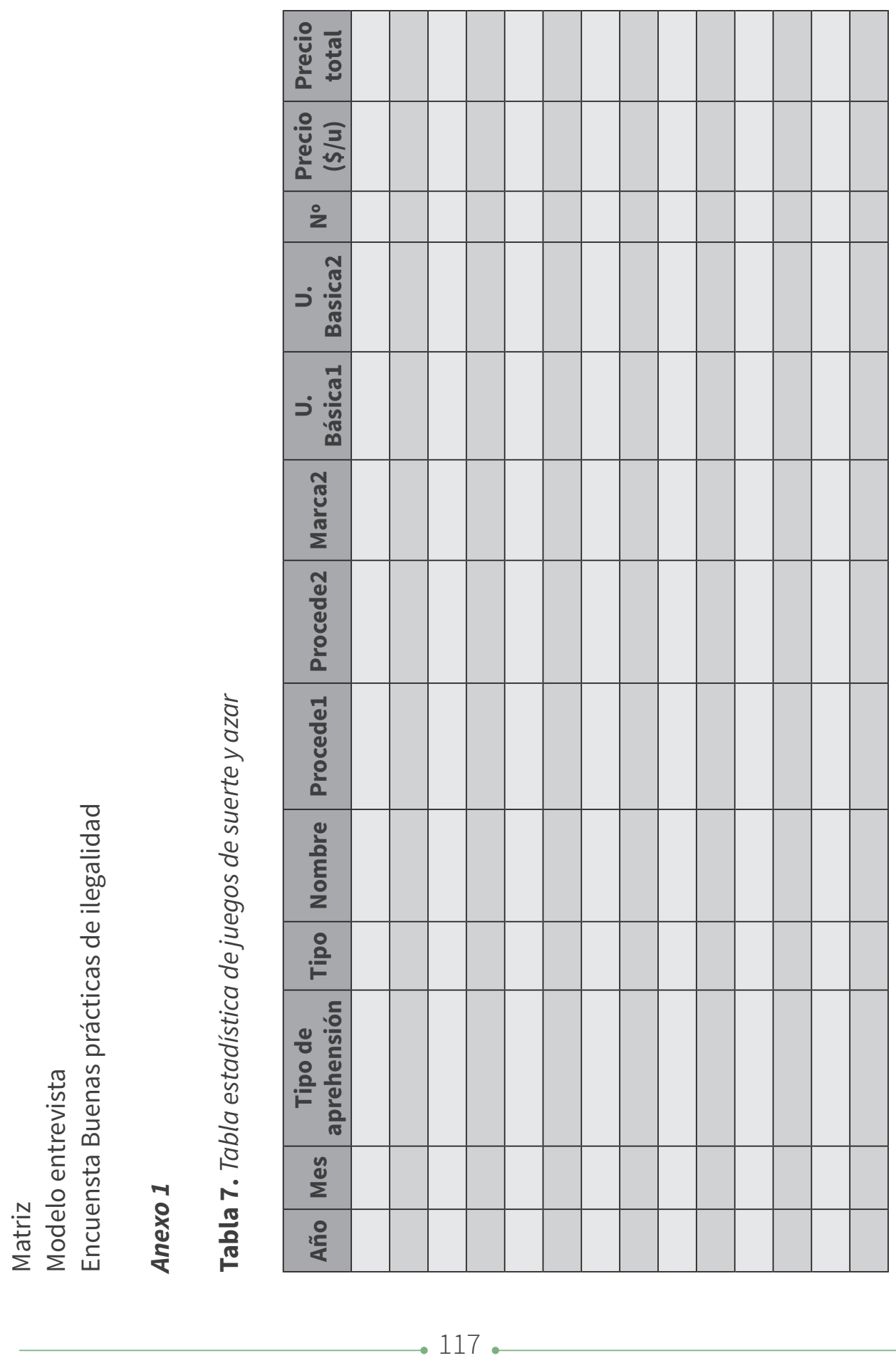




\section{Anexo 2}

\section{Entrevista: Juegos de Suerte y Azar}

Esta entrevista pretende identificar temas concretos sobre el monopolio de juegos de suerte y azar, y sobre la estrategia que actualmente implementa Lotería de Medellín y el Tecnológico de Antioquia en el fortalecimiento de la renta. En ese sentido, se busca conocer a través de la experiencia de funcionarios información importante para el desarrollo de un estudio de impacto. En el ejercicio de organizar los datos y demás, para decantar y plantear más adelante los indicadores que permitan realizar el ejercicio investigativo. Solicitamos que por favor nos apoyara con esta información en la medida de lo posible:

1. ¿Nos puede hablar un poco sobre el inicio de la estrategia y su desarrollo en este tiempo?

2. En el desarrollo de la estrategia ¿qué considera usted es el mayor aporte a la renta de juegos de suerte y azar?

3. ¿Cuál normatividad nos habla sobre el manejo de esta renta?

4. ¿Quiénes son distribuidores de Lotería y cuántos son?

5. ¿Cuántas personas y en qué funciones están vinculadas con la Lotería de Medellín?

6. ¿Cuántos puestos de distribución tienen en el departamento?

7. ¿Cómo es el tipo de vinculación con los expendedores y cuántos hay?

8. ¿Puede compartirnos una caracterización de cada uno de los juegos asociados a la estrategia? o ¿documentos institucionales?

9. ¿Cuáles acciones institucionales considera usted como buenas prácticas en relación con los juegos de suerte y azar?

10. ¿Qué recomendaciones tiene para el tema en cuestión?

\section{Anexo 3}

\section{Encuesta: Buenas Prácticas sobre Cultura de la Legalidad}

Esta encuesta pretende identificar las buenas prácticas sobre cultura de la legalidad que fortalecen las rentas departamentales en las subregiones de Antioquia. Hace parte de la estrategia "Control Integral a las Rentas Ilícitas", que actualmente adelanta la Lotería de Medellín y el Tecnológico de Antioquia sobre los monopolios rentísticos de juegos de suerte y azar. 
En este sentido, se busca conocer, a través de la experiencia en campo de los funcionarios departamentales, cuáles son los fraudes más frecuentes en dichas rentas y las estrategias, acciones y herramientas que se tienen en buenas prácticas. Todo esto con el objetivo de sistematizar los procesos y replicarlos de manera que puedan fortalecer los recursos públicos en aras de favorecer la inversión social.

\section{Dirección de correo electrónico}

\section{Escriba el municipio al que pertenece}

\section{Sobre la Estrategia Integral de Control a las Rentas Ilícitas}

En esta sección se busca explorar el conocimiento sobre la estrategia integral a las rentas ilícitas y la cultura de la legalidad.

Tiene conocimiento sobre la Estrategia Integral al control de las rentas ilícitas.

$\square$ Sí

$\square$ No

¿Cuál de estos componentes de la estrategia considera que es más importante para el fortalecimiento en buenas prácticas de las rentas departamentales?

1. Sensibilización y comunicación pública frente a la cultura de la legalidad

2. Capacitación y formación a las autoridades civiles, policiales, judiciales, administrativas, distribuidores y comerciantes; comunidad y públicos específicos

3. Proceso administrativo, operativo y judicial

4. Participación ciudadana 
Sobre la cultura de la legalidad, ¿cuál de estas afirmaciones considera más adecuada?

1. Una construcción que realizan los diferentes actores de la sociedad para regularse a través del cumplimiento efectivo de las normas que se han reglamentado y legitimado socialmente.

2. Acciones y estrategias que implementan los entes departamentales para regular y ejercer control social y territorial y combatir la ilegalidad.

3. Unas prácticas ciudadanas que se legitiman socialmente para la autorregulación en sus territorios.

\section{¿Por qué eligió la opción anterior?}

¿Cuál de estos componentes considera que tienen un mayor aporte a la cultura de la legalidad?

1. Sensibilización y comunicación pública frente a la cultura de la legalidad

2. Capacitación y formación a las autoridades civiles, policiales, judiciales, administrativas, distribuidores y comerciantes; comunidad y públicos específicos

3. Proceso administrativo, operativo y judicial

4. Participación ciudadana

\section{Sobre Rentas Departamentales}

Califique de 1 a 3 el impacto en ingresos que tienen las rentas en su municipio.

Donde

$1=$ Cero ingresos

$2=$ Muy pocos ingresos

$3=$ Muchos ingresos

Monopolio de alcoholes potables y licores destilados

Cero ingresos 123 Muchos ingresos 
Monopolio de juegos de suerte y azar

Cero ingresos 123 Muchos ingresos

Impuesto de degüello

Cero ingresos 123 Muchos ingresos

Apropiación de hidrocarburos y sobretasa a la gasolina

Cero ingresos 123 Muchos ingresos

Impuesto al consumo de cigarrillos y tabaco elaborado

Cero ingresos 123 Muchos ingresos

¿Cuál de las siguientes rentas sobresale en términos de prácticas económicas y sociales en su municipio? Tenga en cuenta que de esta respuesta dependerá la selección de las siguientes preguntas.

- Monopolio en juegos de suerte y azar (Ir a la sección Monopolio en juegos de suerte y azar)

- Impuesto de degüello (Ir a la sección Impuesto de degüello)

- Apropiación de hidrocarburos y sobretasa a la gasolina (Ir a la sección Apropiación de hidrocarburos)

- Impuesto al consumo de cigarrillos y tabaco elaborado (Ir a la sección Impuesto al consumo de cigarrillos)

Monopolios de juegos de suerte y azar

De cuál de los siguientes fraudes tiene conocimiento que se presentan en su municipio

- Adulteración de la lotería de Medellín (cualquier modalidad que conozca)

- Chance ilegal

- Sorteos promocionales y rifas sin la debida autorización

Otro

¿Cuál de los fraudes anteriores es más frecuente?

- Adulteración de la lotería de Medellín (cualquier modalidad que conozca)

- Chance ilegal 
- Sorteos promocionales y rifas sin la debida autorización

Otro

De 1 a 3, elija cuál cree que es el impacto económico que tiene la ocurrencia del fraude que eligió

Poco impacto 123 Mucho impacto

En qué dimensiones cree que impactan los fraudes anteriormente enunciados

a) Dimensión social: dinámicas sociales, comunitarias y vecinales

b) Dimensión económica: afectación en los ingresos a nivel familiar, comunitario y regional

c) Dimensión legal y normativa: incumplimiento de la disposición normativa de la región y la nación

d) Las opciones a, b, y c

e) Las opciones $a$ y $b$

f) Las opciones b y c

g) Las opciones a y c

Explique en breves palabras su selección de la pregunta anterior

Enuncie tres ( 3 ) buenas prácticas que puedan contrarrestar los fraudes asociados al monopolio de juegos de suerte y azar

Por favor no olvide pasar a la última sección de la encuesta: Buenas prácticas de legalidad 


\section{Buenas prácticas de legalidad}

¿Cuál de las siguientes opciones define mejor para usted el concepto de buenas prácticas de legalidad en el marco de las rentas departamentales?

- Acciones aprobadas socialmente estipuladas por la ley.

- Acciones aprobadas socialmente a partir de valores y principios establecidos.

- Acciones aprobadas institucionalmente con un fin específico.

Estimar el ejercicio de buenas prácticas de legalidad como elemento fundamental de la Estrategia Integral permite:
a. Incentivar cambios en el componente tributario y judicial
b. Incentivar a nuevos ejercicios sociales y culturales
c. Incentivar el desarrollo económico del departamento
d. La opción a y b
e. La opción a y c
f. La opción b y c
g. Todas las anteriores

¿Cuál cree que es su rol como funcionario público para aportar a la cultura de la legalidad?

- Propositivo de nuevas estrategias para la ciudadanía.

- Aportante al proceso administrativo, operativo y judicial.

- De control social frente a las infracciones de la ciudadanía.

Otra

¿Cuál cree que es la responsabilidad de la ciudadanía en materia de buenas prácticas de legalidad? 
En comparación con administraciones anteriores, evalúe de 1 a 3 cuál ha sido el impacto de las políticas públicas implementadas para el fortalecimiento de las rentas departamentales.

Bajo impacto 123 Mucho impacto en el fortalecimiento en el fortalecimiento

Enuncie algunas recomendaciones que tenga sobre el tema de la encuesta

Agradecemos por su tiempo

En cuanto se tengan los resultados del proceso de investigación, podrá tener acceso a la sistematización. 

Impreso por:

Divegraficas S.A.S.

Cra. 53 \#54-30 Medellín, Antioquia

Tel: 3225096 



\section{La ilegalidad en \\ Antioguia en los juegos de suerte y azar}

